Portland State University

PDXScholar

Fall 12-9-2014

\title{
Strontium, Lead, and Oxygen Isotopic Signatures of Mid-Miocene Silicic Volcanism in Eastern Oregon
}

\author{
Emily Nancy Hess \\ Portland State University
}

Follow this and additional works at: https://pdxscholar.library.pdx.edu/open_access_etds

Part of the Stratigraphy Commons, and the Volcanology Commons Let us know how access to this document benefits you.

\section{Recommended Citation}

Hess, Emily Nancy, "Strontium, Lead, and Oxygen Isotopic Signatures of Mid-Miocene Silicic Volcanism in Eastern Oregon" (2014). Dissertations and Theses. Paper 2079.

https://doi.org/10.15760/etd.2077

This Thesis is brought to you for free and open access. It has been accepted for inclusion in Dissertations and Theses by an authorized administrator of PDXScholar. Please contact us if we can make this document more accessible: pdxscholar@pdx.edu. 
Strontium, Lead, and Oxygen Isotopic Signatures of Mid-Miocene Silicic

\title{
Volcanism in Eastern Oregon
}

\author{
by \\ Emily Nancy Hess
}

A thesis submitted in partial fulfillment of the requirements for the degree of

\author{
Master of Science \\ in \\ Geology
}

Thesis Committee:

Martin J. Streck, Chair

Frank C. Ramos

John Bershaw

Portland State University

2014 


\begin{abstract}
Widespread, mid-Miocene rhyolite volcanism of eastern Oregon that are coeval or slightly postdate flood basalts of the Columbia River Basalt Province allows for mapping crustal domains using radiogenic and stable isotopes. Rhyolites are thought to be derived in large part by partial melting of the crust and thus yield direct information on the composition of the crust. Silicic volcanism is expressed in the form of numerous domes and tuffs exposed over a wide area $(\sim 300 \mathrm{~km}$ in N-S dimension and $\sim 200 \mathrm{~km}$ in E-W dimension) west of the presumed craton boundary, which runs parallel but mostly east of the Oregon-Idaho state border as delineated by geophysical characteristics and isotopic transitions, including the ${ }^{87} \mathrm{Sr} /{ }^{86} \mathrm{Sr}_{\mathrm{i}}=0.7060$ line $(\mathrm{MSL})$ and ${ }^{87} \mathrm{Sr} /{ }^{86} \mathrm{Sr}_{\mathrm{i}}=0.7040$ line (CSL). ${ }^{87} \mathrm{Sr} /{ }^{86} \mathrm{Sr}_{\mathrm{i}}$ of twenty-seven silicic units are variable and some are high. Sr isotopic ratios are inconsistent with the location of the traditional MSL and CSL boundaries. A primary control on the ${ }^{87} \mathrm{Sr} /{ }^{86} \mathrm{Sr}_{\mathrm{i}}$ isotope variations may reflect changes in the crustal make-up of Paleozoic accreted terranes of a particular area rather than arising from a westward-dipping decollement that moved cratonic lithosphere below accreted terranes in eastern Oregon. A secondary control on observed isotopic ratios may be related to the amount and composition of basalt involved in the generation of rhyolites. This could lead to higher or lower ${ }^{87} \mathrm{Sr} /{ }^{86} \mathrm{Sr}_{\mathrm{i}}$ relative to the surrounding crust because de facto coeval mafic magmas of the Columbia River Basalt Group have a wide range of Sr isotopic signatures.
\end{abstract}

While $\mathrm{Pb}$ isotope data is incomplete for all samples of this study, the available data indicate a significant range in $\mathrm{Pb}$ isotopes. Yet, data of individual regions tend to 
plot close to one another relative to the entire data distribution. Comparison of samples from this study in a more regional view indicates the samples generally fall within the previously defined lead isotope boundaries of the main-phase Columbia River Basalt Group lavas.

$\delta^{18} \mathrm{O}$ values range from below $2 \%$ to above $9 \%$. In addition, there is a crude trend of rhyolites having lower $\delta^{18} \mathrm{O}$ and more radiogenic ${ }^{87} \mathrm{Sr} /{ }^{86} \mathrm{Sr}_{\mathrm{i}}$ ratios. The lowest oxygen ratios $(<2 \%$ ) are found in rhyolites $\sim 80 \mathrm{~km}$ west of the cratonic margin, potentially reflecting remelting or assimilation of hydrothermally altered crust. Low $\delta^{18} \mathrm{O}$ of selected rhyolite flows cannot be explained by remelting of Cretaceous plutons of the Idaho Batholith and appear irreconcilable with remelting of altered silicic rocks at centers of multiple, confocal caldera cycles- both processes that have been proposed to explain low $\delta^{18} \mathrm{O}$ of rhyolites of the Snake River Plain-Yellowstone area. 


\section{ACKNOWLEDGEMENTS}

I would like to thank several people who helped me with this project and provided me with a better understanding of geologic processes. Thanks to my committee - Martin Streck, Frank Ramos, and John Bershaw - for their efforts to review and revise my work. Martin Streck has been an outstanding advisor; he provided me with this intriguing project and has supported me during all aspects of it, despite having an unceasing list of other obligations.

I have been fortunate to have superb lab mentors who have spent considerable time and effort teaching me proper lab techniques and the workings of analytical instruments. These lab mentors have included Frank Ramos and his students at New Mexico State University, Dan Miggins at Oregon State University, and Rick Conrey at Washington State University.

My friends at PSU were vital to ensuring my graduate work was enjoyable. In particular, Elizabeth Westby was an invaluable lab and conference partner, Courtney Savoie was a delightful companion during fieldwork in eastern Oregon, and Adam Large and Phil Marcy were appreciated contributors during "hard rock" office conversations.

Finally, I would like to thank my family for their support. Their pride in my accomplishments helped give me the confidence to pursue a master's degree. My parents bestowed to me the initial spark of scientific curiosity while my husband, Bjorn, has continued to encourage me to seek out the answers to the riddles of the universe. 
TABLE OF CONTENTS

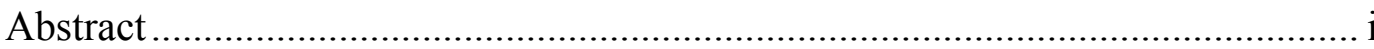

Acknowledgements ....................................................................................... ii

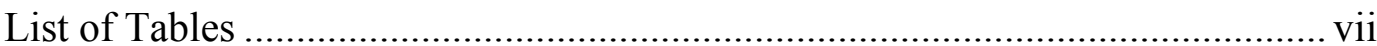

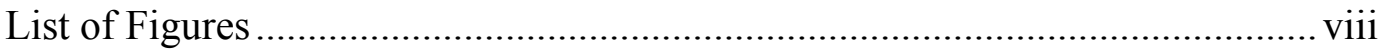

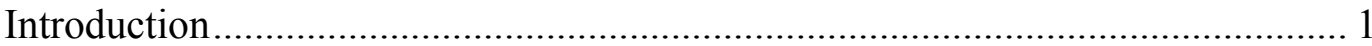

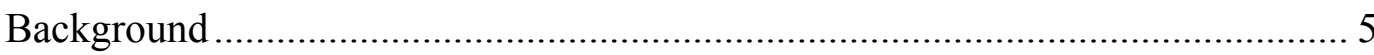

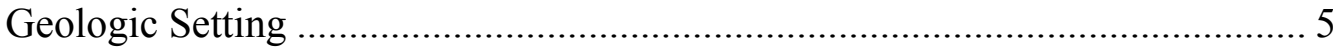

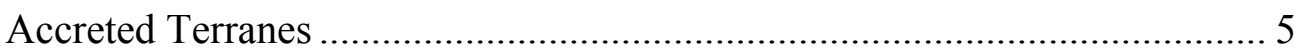

Distribution of Initial Strontium Isotope Ratios - Historic Perspective ......... 8

Columbia River Basalt Province............................................................. 18

Silicic Volcanic Centers of this Study ........................................................ 19

${ }^{87} \mathrm{Rb}_{-}{ }^{87} \mathrm{Sr}$ Decay, the ${ }^{87} \mathrm{Sr} /{ }^{86} \mathrm{Sr}$ Isotope System, and the MSL and CSL ........... 21

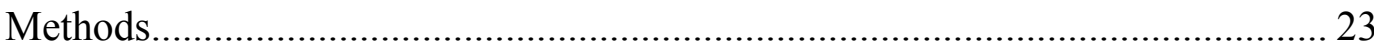

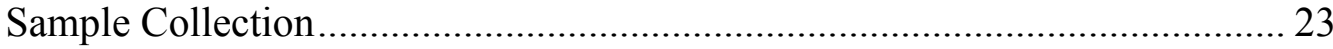

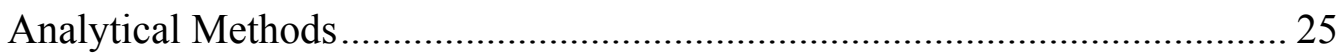

Thin Section and Petrographic Analyses ................................................... 25

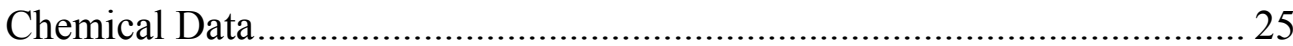

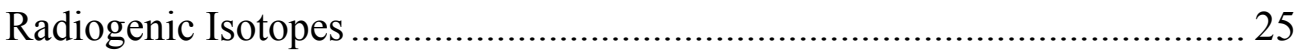

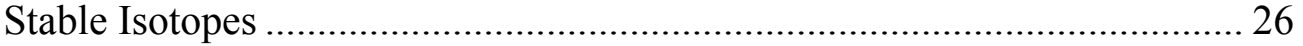

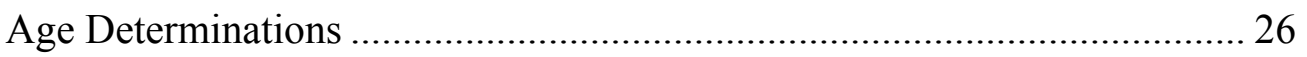

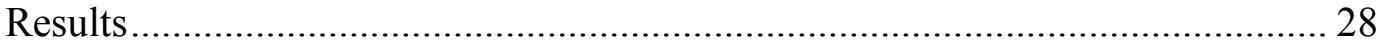

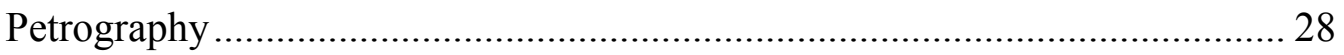




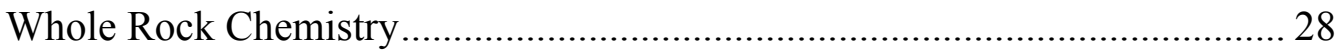

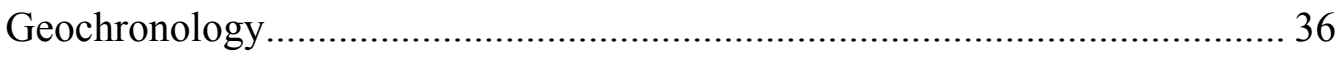

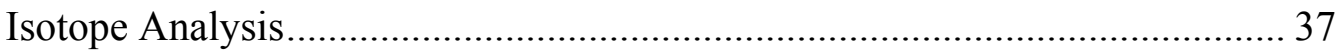

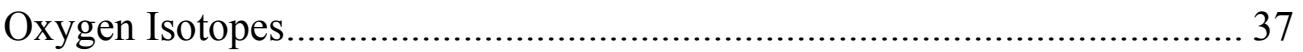

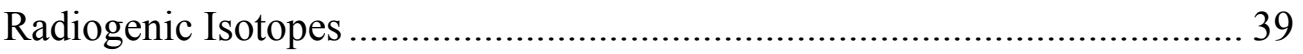

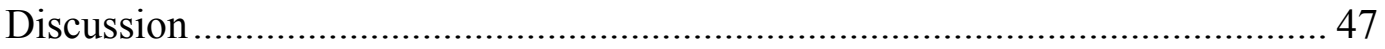

Position of Terrane/Craton Boundary ............................................................... 47

Variable Accreted Terrane Crust ..................................................................... 49

Variations Induced by Variable Amounts of Basalt Ancestry........................... 53

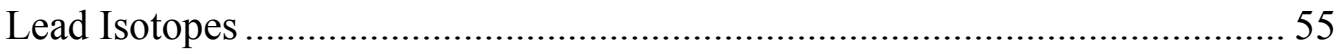

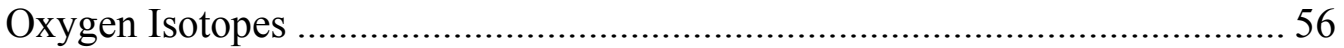

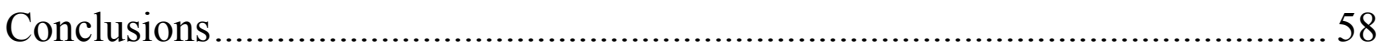

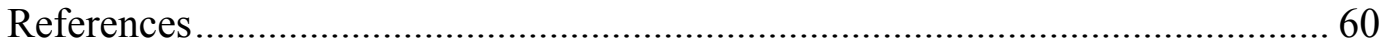

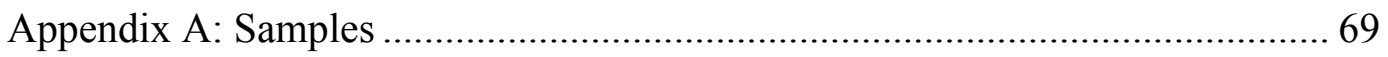

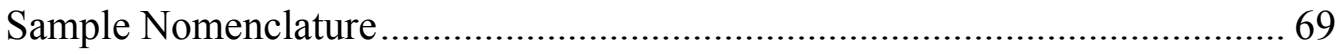

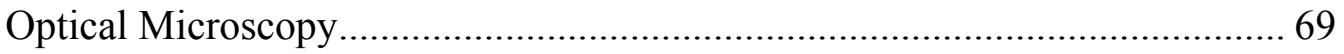

Appendix B: XRF and ICP-MS Chemical Data ………………………............. 72

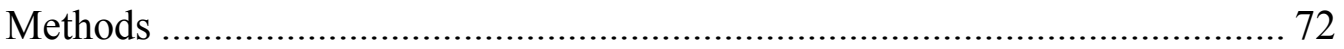

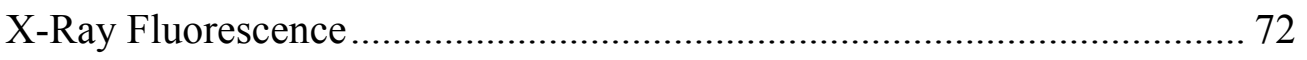

Inductively Coupled Plasma Mass Spectrometry ……................................. 72

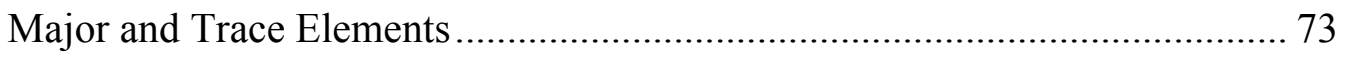

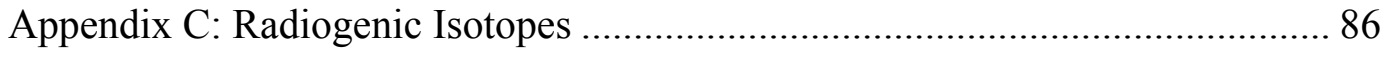




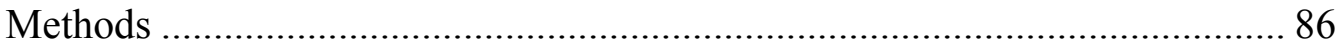

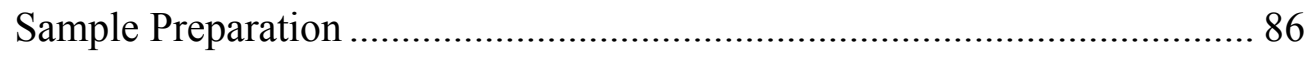

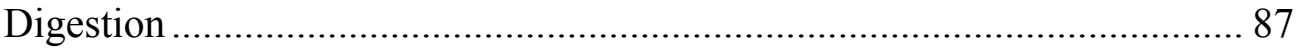

Chromatography Preparation and Sample Purification ................................ 88

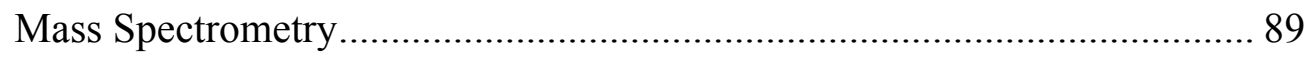

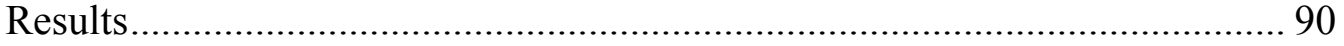

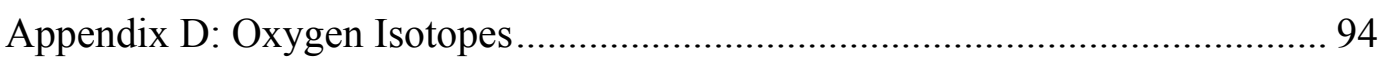

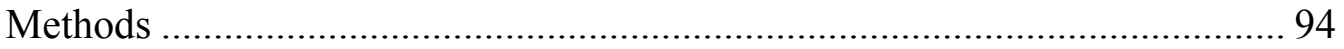

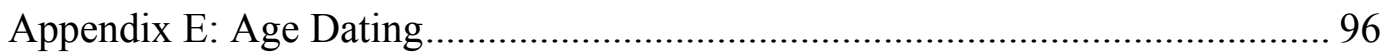

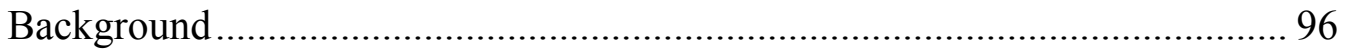

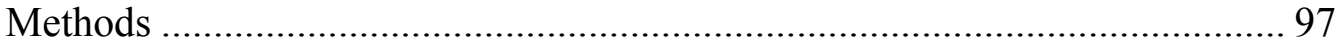




\section{LIST OF TABLES}

Table 1. Published radiometric age determinations for silicic centers associated with this study. Some units have several age determinations. Only the four most recent age dates are shown. 20

Table 2. Unit assignments and locations for each sample in this study. Latitude and longitude are listed in decimal degrees. The inferred source location for Dinner Creek Tuff is $44.04^{\circ} \mathrm{N}, 118.17^{\circ} \mathrm{W}$ and the inferred source location for Devine Canyon Tuff is $43.55^{\circ} \mathrm{N}, 118.78^{\circ} \mathrm{W}$.

Table 3. Ar-Ar age data for select rhyolites. MS-11-15 and TF-88A ages are from Marcy et al. (2013). AS-SV-151 and AS-SV-190 ages are from Steiner per. comm., while all other data were obtained in this study. Ages were calculated with FCT age of 28.201 Ma (Kuiper et al., 2008).

Table 4. Oxygen isotopic compositions of samples acquired from this study. The magmatic $\delta^{18} \mathrm{O}$ values are calculated using equations D-1, D-2, and D-3 (Appendix D), depending on the mineral analyzed. 38

Table 5. Sr isotope data for feldspar (fsp) and groundmass (GM). ${ }^{87} \mathrm{Sr} /{ }^{86} \mathrm{Sr}$ (initial) calculated using equation $\mathrm{C}-1$ (Appendix C). Concentrations of $\mathrm{Sr}$ and $\mathrm{Rb}$ are

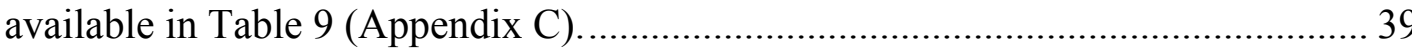

Table 6. $\mathrm{Pb}$ isotopic compositions of groundmass and whole rock. 40 


\section{LIST OF FIGURES}

Figure 1. Location map of 17 to $\sim 10$ Ma rhyolites in red (after Christiansen et al., 2002; Ma et al., 2009; Steiner and Streck, 2013) and basaltic lava flows of the CRBG in green (after Camp and Ross, 2004). Dark brown dashed lines depict terrane boundaries (after LaMaskin et al., 2009). Included are the MSL (dark blue) and the CSL (light blue) modified from Pierce and Morgan (2009), which demarcates the western edge of North American craton. White box shows the areal coverage of

Figure 29.

Figure 2. Map illustrating distribution of accreted terranes, the Idaho batholith, and Cenozoic cover of the Blue Mountains province from Tumpane (2010) with ${ }^{87} \mathrm{Sr} /{ }^{86} \mathrm{Sr}_{\mathrm{i}}=0.706$ line modified from Armstrong et al. (1977). 6

Figure 3. Map from Armstrong et al. (1977) showing ${ }^{87} \mathrm{Sr} /{ }^{86} \mathrm{Sr}_{\mathrm{i}}$ for Mesozoic and Cenozoic igneous rocks in the northwestern United States (references used are listed in Armstrong et al., 1977).

Figure 4. East-west variations in ${ }^{87} \mathrm{Sr} /{ }^{86} \mathrm{Sr}_{\mathrm{i}}$ of silicic volcanic rocks (Savov et al., 2009). Samples are: Yellowstone intracaldera (Y-IC) and extracaldera (Y-EC) rhyolites, Bruneau-Jarbridge (BJ) rhyolites, eastern Oregon (EOR) rhyolites; miscellaneous (Misc) samples include Craters of the Moon (COM) latite and Big Southern Butte (BSB) rhyolite. Vertical dashed line shows position of western Idaho suture zone (WISZ). Gray shading indicates compositional range for Neogene basalts from the High Lava Plain and Snake River Plain (after Savov et al., 2009). 10 
Figure 5. Location of CSL and MSL in western United States, from Kistler and Peterman (1978).

Figure 6. CSL (*), MSL (x), and other major geologic features in the western United States associated with the late Cenozoic track of the Yellowstone hot spot (Pierce and Morgan, 1992).

Figure 7. Map of northwestern United States showing the location of MSL and features associated with Cenozoic volcanism (left). Schematic lithospheric cross sections and ${ }^{87} \mathrm{Sr} /{ }^{86} \mathrm{Sr}$ isochrones from different events (right) (Leeman et al., 1992)..... 14

Figure 8. Map of the WISZ outlined in red. Red circles correspond to samples with Sr isotope data and black lines correspond to age traverses (Fleck and Criss, 2004)... 16

Figure 9. Map showing location of the Snake River-Yellowstone hot spot track and associated volcanism (Pierce and Morgan, 2009). The locations of the CSL (._.) and MSL (...) lines are also shown. 17

Figure 10. Map of digital topography of eastern Oregon, northern Nevada, and southern Idaho depicting eruptive complexes associated with the Snake River-Yellowstone hot spot track (Shervais and Hanan, 2008). The locations of the ${ }^{87} \mathrm{Sr} /{ }^{86} \mathrm{Sr}_{\mathrm{i}}=0.7040$ (CSL) and 0.7060 (MSL) lines are displayed. 18

Figure 11. Location map for all samples collected for this study. 23

Figure 12. Total alkali-silica diagram for samples of this study (Le Bas, 1986). All but two samples are classified as rhyolite. 29 
Figure 13. Molar A/NK versus A/CNK (Maniar and Piccoli, 1989) for samples; one sample falls in the peralkaline field while the remainder are in the metaluminous and the peraluminous fields. 29

Figure 14. Diagram illustrating $\mathrm{CaO}$ versus $\mathrm{SiO}_{2}$. Overall calcium contents decline with increasing silica contents. Samples from the western and southern transect have less calcium than Littlefield Rhyolite and samples from the northern transect, likely because they tend to have a higher silica content. 30

Figure 15. Diagram illustrating $\mathrm{FeO}^{*}$ versus $\mathrm{SiO}_{2}$. Overall $\mathrm{FeO} *$ content declines with increasing silica, following the same trend as calcium (Figure 14)............................ 30

Figure 16. $\left(\mathrm{K}_{2} \mathrm{O}+\mathrm{Na}_{2} \mathrm{O}\right) / \mathrm{CaO}$ versus $\mathrm{Zr}+\mathrm{Nb}+\mathrm{Ce}+\mathrm{Y}$ diagram to differentiate A-type granites and rhyolites from other types of granites and rhyolites (after Whalen et al., 1987). 31

Figure 17. Diagram illustrating europium anomalies of rhyolites (calculated using Eq. 1).

Figure 18. Average crust-normalized multi-element diagram of rhyolites from the northern transect. EJ-12-22B (dacite of Ironside Mountain) has the greatest $\mathrm{Nb}$ anomaly. 33

Figure 19. Average crust-normalized multi-element diagram of rhyolites from the southern transect. There is greater variation in the trace element concentrations in the southern transect relative to the northern transect (Figure 18). 34 
Figure 20. Average crust-normalized multi-element diagram of rhyolites from the western and central transect. MS-13-12 (Black Butte Rhyolite) creates the greatest variation in trace element concentrations among the samples from these transects. 34

Figure 21. Average crust-normalized multi-element diagram of Dinner Creek samples. MS-11-20, which is classified as a dacite, has the greatest variation in trace element concentrations among the Dinner Creek samples. 35

Figure 22. Average crust-normalized multi-element diagram of the Cottonwood Mountain, Bully Creek, and Littlefield Rhyolite. EJ-12-10 (upper Littlefield Rhyolite) has significant variation relative to the other rhyolites..... 35

Figure 23. Average crust-normalized multi-element diagram of rhyolites from the Owyhee region. TF-88A (Three Fingers Intra-caldera Rhyolite) has the greatest Ba, Sr, and $\mathrm{P}$ anomaly 36

Figure 24. Variation diagram illustrating ${ }^{87} \mathrm{Sr} /{ }^{86} \mathrm{Sr}_{\mathrm{i}}$ versus ${ }^{206} \mathrm{~Pb} /{ }^{204} \mathrm{~Pb}$ signatures. ${ }^{87} \mathrm{Sr} /{ }^{86} \mathrm{Sr}_{\mathrm{i}}$ data are from feldspars; if there are no data for feldspar of a particular sample, the ${ }^{87} \mathrm{Sr} /{ }^{86} \mathrm{Sr}_{\mathrm{i}}$ data are from groundmass 42

Figure $25 .{ }^{208} \mathrm{~Pb} /{ }^{204} \mathrm{~Pb}$ versus ${ }^{206} \mathrm{~Pb} /{ }^{204} \mathrm{~Pb}$ variation diagram illustrating rhyolite groundmass signatures. 42

Figure 26. ${ }^{207} \mathrm{~Pb} /{ }^{204} \mathrm{~Pb}$ versus ${ }^{206} \mathrm{~Pb} /{ }^{204} \mathrm{~Pb}$ variation diagram illustrating rhyolite groundmass signatures. Dinner Creek sample MS-PCIT-1A is an outlier at ${ }^{207} \mathrm{~Pb} /{ }^{204} \mathrm{~Pb}=16.000$ and is not included in figure. 43 
Figure 27. ${ }^{87} \mathrm{Sr} /{ }^{86} \mathrm{Sr}_{\mathrm{i}}$ versus calculated $\delta^{18} \mathrm{O}$ magma (\%) variation diagram illustrating significant range in $\delta^{18} \mathrm{O} \cdot{ }^{87} \mathrm{Sr} /{ }^{86} \mathrm{Sr}_{\mathrm{i}}$ data are from feldspars; if there are no data for feldspar of a particular sample, the ${ }^{87} \mathrm{Sr}^{86} \mathrm{Sr}_{i}$ data are from groundmass.

Figure 28. Diagram illustrating $\mathrm{Zr}+\mathrm{Nb}+\mathrm{Ce}+\mathrm{Y}(\mathrm{ppm})$ of whole rocks and corresponding ${ }^{87} \mathrm{Sr}^{86} \mathrm{Sr}_{\mathrm{i}} \cdot{ }^{87} \mathrm{Sr} /{ }^{86} \mathrm{Sr}_{\mathrm{i}}$ data are from feldspars; if there are no data for feldspar of a particular sample, the ${ }^{87} \mathrm{Sr} /{ }^{86} \mathrm{Sr}_{i}$ data are from groundmass. The majority of samples are classified as A-type rhyolites, after Whalen et al. (1987), and A-type rhyolites are in general more radiogenic than others. Samples are coded for whole rock $\mathrm{SiO}_{2}$ (wt.\%) content; black is dacite $(<70 \%)$, grey is low-silica rhyolite $(<75 \%)$, unfilled is high-silica rhyolite $(>75 \%)$. 45

Figure 29. Map illustrating sample locations with age corrected ${ }^{87} \mathrm{Sr} /{ }^{86} \mathrm{Sr}_{i}$ ratios from feldspar or groundmass. Shading of icon is defined as: left part of icon reflects ${ }^{87} \mathrm{Sr}^{86}{ }^{86} r_{\text {i }}$ ratio of feldspar while the right part of icon reflects ${ }^{87} \mathrm{Sr}^{86}{ }^{86} r_{i}$ ratio of groundmass. The traditional ${ }^{87} \mathrm{Sr}^{86} \mathrm{Sr}_{\mathrm{i}}=0.7040$ and 0.7060 isochrones are represented by dashed black lines are after Pierce and Morgan (2009). Our proposed 0.7040 (orange) and 0.7060 (blue) ${ }^{87} \mathrm{Sr}^{86} \mathrm{Sr}_{\mathrm{i}}$ isochrones are dashed. Literature data in the region are included as abbreviations: BB- Burns Butte, IM- Iron Mt, PBPalomino Butte, DB- Duck Creek Butte, IB- Indian Creek Butte (Streck and Grunder, 2008; Ford, 2011). Devine Canyon Tuff and Dinner Creek Tuff symbols correspond to inferred source locations for these tuffs, although samples were collected from different locations (Table 2). 46 
Figure $30 .{ }^{87} \mathrm{Sr} /{ }^{86} \mathrm{Sr}_{\mathrm{i}}-\varepsilon \mathrm{Nd}$ diagram showing fields for basement rocks of the Olds Ferry and Wallowa terranes (from Tumpane, 2010). Both sets of basement rocks have ${ }^{87} \mathrm{Sr} /{ }^{86} \mathrm{Sr}_{\mathrm{i}}$ and $\varepsilon \mathrm{Nd}$ values indicative of an island arc setting and little evidence for

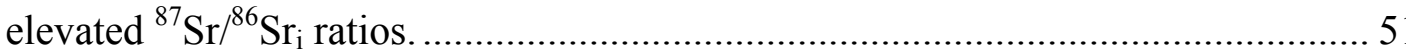

Figure 31. Sr-Pb isotope diagrams illustrating relations among CRBG lavas and Pacific mid-ocean-ridge basalts (after Wolff et al., 2008) with rhyolites from this study. (a) ${ }^{207} \mathrm{~Pb} /{ }^{206} \mathrm{~Pb}$ versus ${ }^{208} \mathrm{~Pb} /{ }^{206} \mathrm{~Pb}$ and $(\mathrm{b}){ }^{87} \mathrm{Sr} /{ }^{86} \mathrm{Sr}_{\mathrm{i}}$ versus ${ }^{206} \mathrm{~Pb} /{ }^{204} \mathrm{~Pb}$. Black dotted lines are mixtures between Imnaha-source mantle and depleted mantle (Wolff et al., 2008). Plum-colored arrows labeled "crustal contamination" represent the extent of interaction between Imnaha magmas and crust, which is represented by rhyolite lavas in the vicinity of the CRBG magma storage zone (Wolff et al., 2008). 55 


\section{INTRODUCTION}

During mid-Miocene time, eruption of voluminous flood basalts and widespread eruptions of rhyolite ash flows and lava flows occurred in eastern Oregon, northern Nevada, and southwestern Idaho (Cummings et al., 2000; Hooper et al., 2002; Shervais and Hanan, 2008; Camp, 2013). At least $\sim 3,900 \mathrm{~km}^{3}$ of silicic magma erupted from centers covering over $\sim 25,000 \mathrm{~km}^{2}$ (Coble and Mahood, 2012). While numerous origins, source materials, and contributing components have been proposed for this volcanism, the majority of workers agree that a mantle plume produced the Columbia River Basalt Group (CRBG) and the Snake River Plain - Yellowstone hotspot track to the east (e.g., Wolff et al., 2008; Camp, 2013).

The McDermitt volcanic field, located on the border of Nevada and Oregon, has been proposed as the initiation site of plume head magmatic activity related to the Yellowstone hotspot track with the continental crust (Pierce and Morgan, 2009; Coble and Mahood, 2012; Camp, 2013) ${ }^{40} \mathrm{Ar} /{ }^{39} \mathrm{Ar}$ ages of silicic rocks around McDermitt caldera are $16.54 \pm 0.11 \mathrm{Ma}$ for a biotite rhyolite and $16.49 \pm 0.04$ Ma for a peralkaline rhyolite (Henry et al., 2006). However, there are numerous silicic centers further north with ages as old as that of the McDermitt center, thus extending the potential crustal interaction area of plume head activity considerably. With a proposed diameter of $\sim 400$ $\mathrm{km}$, the initial impingement of the Yellowstone plume head could have underlied much

of eastern Oregon, northern Nevada, and southwestern Idaho (Coble and Mahood, 2012).

Flood basalts and associated rhyolitic volcanism occurred in an area of significant compositional changes of the lithosphere. Approximately $116^{\circ} \mathrm{W}$ is the boundary that 
separates Precambrian continental crust underlain by old lithospheric mantle from Mesozoic accreted oceanic terranes to the west that were added to the North American continent during the Cretaceous (Leeman et al., 1992). Armstrong et al. (1977) were the first to propose that the cratonic margin is preserved as a sharp isotopic boundary as defined by the ${ }^{87} \mathrm{Sr}^{86} \mathrm{Sr}_{\mathrm{i}}=0.7060$ line (Figure 3). More recent work has further refined the location of the "0.706 line," which was defined by Armstrong et al. (1977) as the Mesozoic Strontium Line (MSL) (e.g., Kistler and Peterman, 1978; Fleck and Criss, 1985; Leeman et al., 1992; Pierce and Morgan, 1992; Fleck and Criss, 2004; Pierce and Morgan, 2009). This isotopic transition from Precambrian crust to Paleozoic accreted terranes was further delineated by the ${ }^{87} \mathrm{Sr}{ }^{86} \mathrm{Sr}_{\mathrm{i}}=0.7040$ (Cenozoic Strontium Line [CSL]; Armstrong et al.,1977). The CSL is thought to parallel the MSL in central Idaho (Figure 1) but diverges west through eastern Oregon to the south (Shervais and Hanan, 2008). Divergence of both boundaries results from the more gradational isotopic transition across this lithospheric boundary in southern Oregon compared to further north. In areas where no appropriate crustal sections are exposed, magmas that formed and/or interacted with the lithosphere on either side of the transition have been used as evidence for the presence of accreted terrane, Precambrian craton, or transitional lithosphere (e.g., Leeman and Whelan, 1983). In this sense, silicic magmas and unfractionated basaltic magmas provide likely complementary evidence. The former characterizes crustal sources while the latter tracks mantle sources (e.g., Savov et al., 2009). In the case of fractionated mafic magmas, crustal, as well as mantle sources, can be mirrored in their isotopic compositions (e.g., Wolff et al., 2008; Wolff and Ramos, 2013). 
Widespread rhyolitic volcanism near the lithospheric transitions in eastern Oregon allows for mapping crustal domains using radiogenic isotopes. Rhyolites of Oregon are thought to be derived in large part by partial melting of the crust, and thus, yield direct information on the composition of the crust (e.g., Streck, 2002; Streck and Grunder, 2008; Ford et al., 2013; Steiner and Streck, 2013). Mid-Miocene silicic volcanism is expressed in the form of numerous domes and tuffs exposed over a wide area $(\sim 300 \mathrm{~km}$ in N-S dimension and $\sim 200 \mathrm{~km}$ in E-W dimension, Figure 1) west of the craton boundary (Cummings et al., 2000; Camp et al., 2003; Ferns and McClaughry, 2013).

This study reports ${ }^{87} \mathrm{Sr}^{86} \mathrm{Sr}_{\mathrm{i}}$ ratios of groundmass and feldspar mineral separates obtained from samples of twenty-seven, mostly mid-Miocene silicic volcanic centers in eastern Oregon. In addition, $\mathrm{Pb}$ and $\mathrm{O}$ isotopes are included to gain insight into source materials for rhyolites. To date, only sparse isotopic data of a few such silicic centers exist (Leeman et al., 1992; Ford, 2011).

This study also reports the age of select rhyolite centers using ${ }^{40} \mathrm{Ar} /{ }^{39} \mathrm{Ar}$ dating. The silicic geologic units in this area are poorly known and little modern age data exist. If these rhyolites are contemporaneous in age with those found in the McDermitt-Virgin Valley area, these silicic volcanic centers likely mark the area where magmatic reservoirs feeding CRBG flood basalts resided. Most of the volume of CRBG lava (Steens, Imnaha, and Grande Ronde basalt members) erupted between 16.7 and 15.6 Ma (Wolff et al., 2008; Tolan et al., 2009; Barry et al., 2013). 


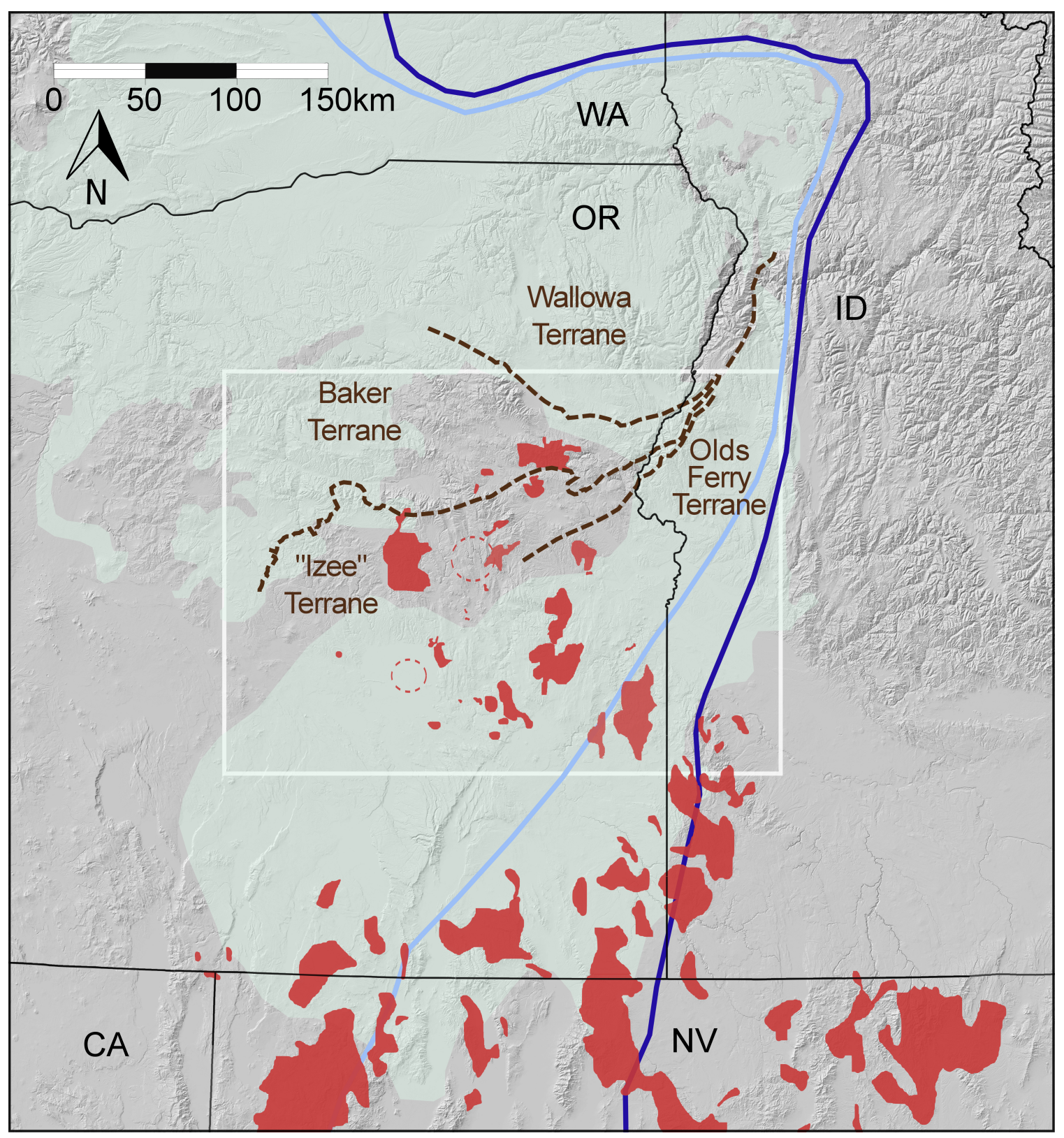

Figure 1. Location map of 17 to $\sim 10$ Ma rhyolites in red (after Christiansen et al., 2002; Ma et al., 2009; Steiner and Streck, 2013) and basaltic lava flows of the CRBG in green (after Camp and Ross, 2004). Dark brown dashed lines depict terrane boundaries (after LaMaskin et al., 2009). Included are the MSL (dark blue) and the CSL (light blue) modified from Pierce and Morgan (2009), which demarcates the western edge of North American craton. White box shows the areal coverage of Figure 29. 


\section{BACKGROUND}

\section{Geologic Setting}

\section{Accreted Terranes}

Prior to the development of an active continental margin in Cretaceous time, numerous oceanic and craton-fringing crustal blocks were accreted onto the western Laurentian margin of North America as allochthonous and para-autocthonous terranes (DeCelles, 2004; Dickinson, 2004). Several competing tectonic models for the evolution of the western U.S. Cordillera exist and estimates for the age of accretion vary (LaMaskin, 2009). The traditionally defined terranes within the Blue Mountains Province are, from north to south, the Wallowa, Baker, Olds Ferry, and Izee terranes (Figure 2). These late Paleozoic and early Mesozoic terranes were accreted in the late Mesozoic (Ferns and McClaughry, 2013). These blocks were variably faulted, folded, and intruded by middle Mesozoic granitic bodies prior to accretion (Ferns and McClaughry, 2013).

The rocks of the Wallowa, Baker, and Olds Ferry terranes originated from oceanic or island arc settings. (Brooks, 1979; Ferns and McClaughry, 2013). Some terrane material has recently been proposed to originate from being deposited after the arc had been accreted to North America - including the rocks of the Izee terrane (Dorsey and LaMaskin, 2007). The terranes are separated either by faults or unconformities that trend to the east or northeast and tend to converge northward towards the western Idaho shear zone (Brooks and Vallier, 1978). Dorsey and LaMaskin (2007) propose the Wallowa and Olds Ferry terranes were separate arcs that were active at the same time due to opposite dipping subduction of an intervening oceanic plate. The collision of the terranes began in 
the Late Triassic with final accretion taking place in the Late Jurassic (Dorsey and LaMaskin, 2007). They suggest the Baker terrane is a composite of the accretionary prisms that formed in front of each arc during subduction. Meanwhile, because the Izee terrane is a regional overlap assemblage that formed after the three tectonic terranes had been united, it should not be referred to as a terrane (Dorsey and LaMaskin, 2007).

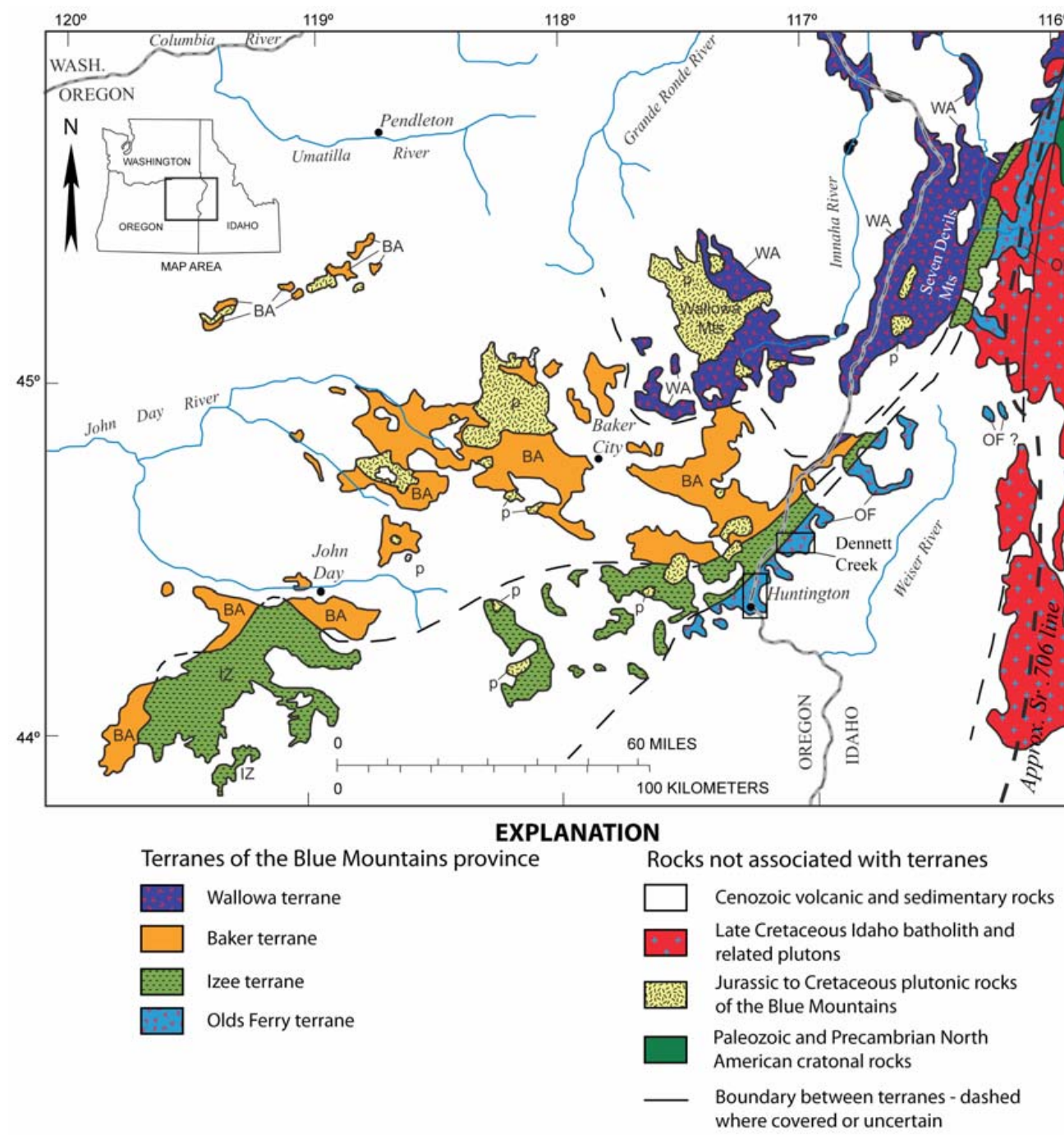

Figure 2. Map illustrating distribution of accreted terranes, the Idaho batholith, and Cenozoic cover of the Blue Mountains province from Tumpane (2010) with ${ }^{87} \mathrm{Sr}^{86} \mathrm{Sr}_{\mathrm{i}}=0.706$ line modified from Armstrong et al. (1977). 
The Wallowa Terrane is a deformed block of Permian and Triassic oceanic island arc composed of volcanic rocks and age-equivalent basinal sedimentary rocks (Ferns and McClaughry, 2013). Its base consists of a complexly deformed mass of lavas, domes, mudflow breccias, and tuffs (Ferns and McClaughry, 2013).

The Baker Terrane separates the Wallowa and Olds Ferry terranes and represents a complexly deformed series of crustal blocks segregated into three components (LaMaskin, 2009). The Bourne subterrane is the northernmost component and consists largely of weakly metamorphosed rocks of oceanic affinity (Ferns and Brooks, 1995). The Greenhorn subterrane is dominated by serpentinite-matrix mélange (Ferns and McClaughry, 2013). The more highly metamorphosed greenschist-facies rocks of the Burnt River Schist that compose the southernmost component (Gilluly, 1937; Kays et al., 1987) are oceanic and island arc fragments (Ferns and McClaughry, 2013). In the Baker terrane, metaplutonic rocks have ${ }^{87} \mathrm{Sr}^{86} \mathrm{Sr}_{\mathrm{i}}=0.7033-0.7034$ while siliceous argillites have ${ }^{87} \mathrm{Sr}^{86} \mathrm{Sr}_{\mathrm{i}}=0.7073-0.7094$ (Schwartz et al., 2010).

The most inboard of the terranes of the Blue Mountains province, and thus, in the most direct contact with cratonic North America is the Olds Ferry terrane (Tumpane, 2010). It consists of carbonate and clastic sedimentary rocks and associated metavolcanic rocks, as well as plutonic rocks of the Huntington Formation (Tumpane, 2010). The most common volcanic rock type is meta-andesite with a submarine origin, as evidenced by the presence of fossiliferous marine clastic beds (Brooks and Vallier, 1978). The Huntington Formation was deposited unconformably on top of plutonic basement rocks of Middle and Late Triassic age and resulted from volcanic activity in the Late Triassic to Early 
Jurassic (Tumpane, 2010). Based on field evidence, geochronology, and geochemistry, Tumpane (2010) split the formation into the lower and upper Huntington Formation. In the Huntington Formation, ${ }^{87} \mathrm{Sr} /{ }^{86} \mathrm{Sr}_{\mathrm{i}}$ ranges from 0.7036 to 0.7057 (Tumpane, 2010).

The Izee terrane does not represent a far-traveled terrane because the rocks were deposited over older rocks and structures of the other terranes (LaMaskin, 2009). According to Dorsey and LaMaskin (2007), the Izee basin formed and subsided deeply on crust from the amalgamated terranes during Early to Late Jurassic time. The growing marine basin provided accommodation space for sediment deposition in a non-volcanic collisional basin. The tectonic closure of a backarc basin, growth of the Cordilleran thrust belt, regional metamorphism, and crustal thickening and mountain building in western Idaho and Nevada occurred in response to terrane-continent collision (Dorsey and LaMaskin, 2007).

In summary, the isotopic signatures of these terranes vary considerably with the Olds Ferry terrane having ${ }^{87} \mathrm{Sr}^{86} \mathrm{Sr}_{\mathrm{i}}$ ratios between the less radiogenic metaplutonic rocks of the Baker terrane and the more radiogenic siliceous argillites of the Baker terrane.

\section{Distribution of Initial Strontium Isotope Ratios - Historic Perspective}

The margin of cratonic North America in Idaho was located at about $116^{\circ} \mathrm{W}$ longitude at the time of terrane accretion (Fleck and Criss, 2004). Armstrong et al. (1977) were the first to recognize this margin as a sharp isotopic boundary separating Precambrian crust to the east from younger Late Paleozoic and Mesozoic accreted lithosphere of oceanic affinity to the west (Figure 3). Armstrong et al. (1977) examined 
granitic rocks emplaced during the Mesozoic and suggested the isotopic change resulted from contamination and assimilation processes involving magmas from the mantle and enclosing crustal rocks.

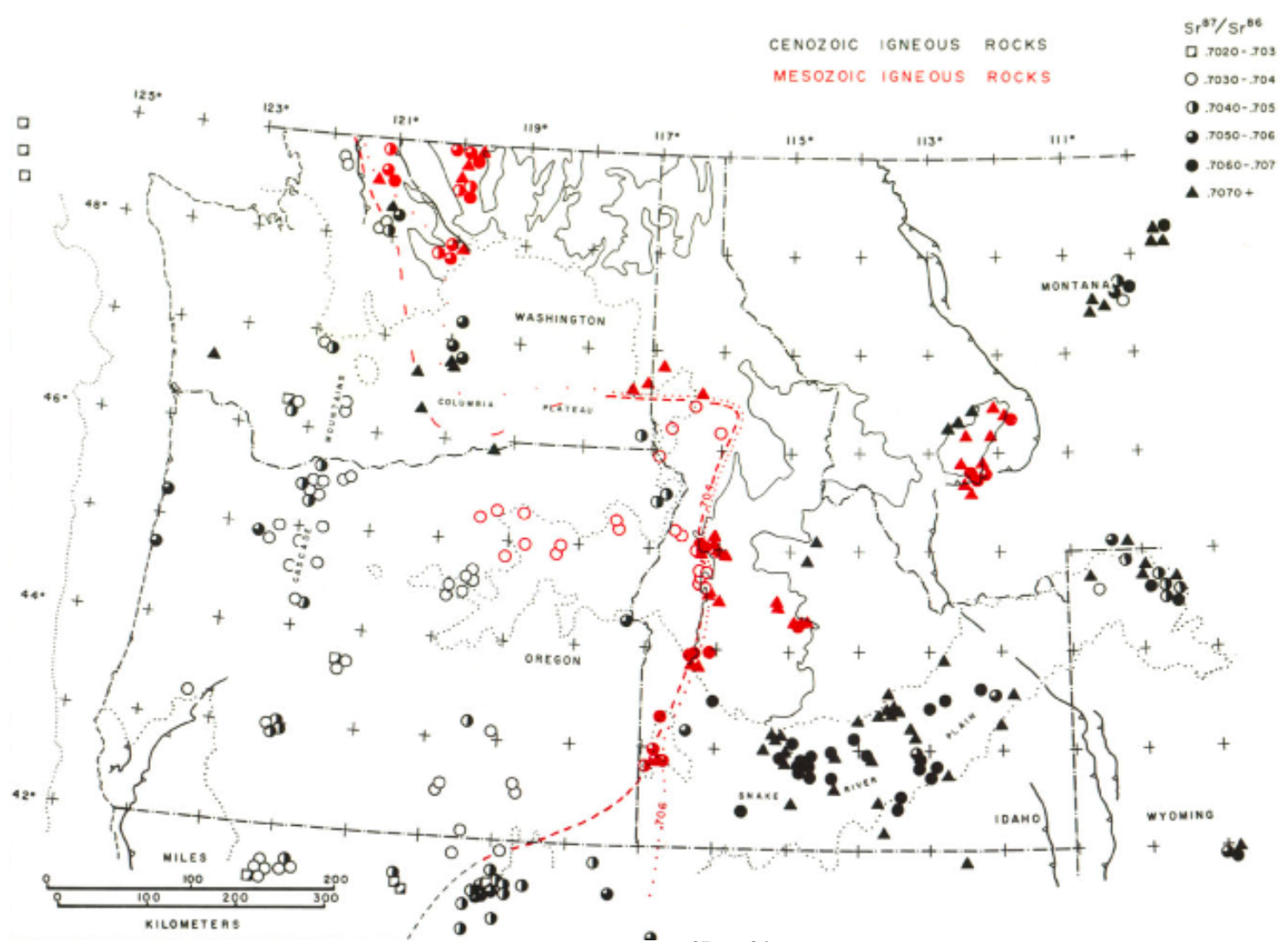

Figure 3. Map from Armstrong et al. (1977) showing ${ }^{87} \mathrm{Sr}^{86} \mathrm{Sr}_{\mathrm{i}}$ for Mesozoic and Cenozoic igneous rocks in the northwestern United States (references used are listed in Armstrong et al., 1977).

Many publications have further refined the location of the MSL (Kistler and

Peterman, 1978; Fleck and Criss, 1985; Leeman et al., 1992; Fleck and Criss, 2004) and the CSL, which is a similar lithospheric boundary that is coincident with the ${ }^{87} \mathrm{Sr}^{86} \mathrm{Sr}_{\mathrm{i}}=$ 0.7060 line in central Idaho but propagates west through eastern Oregon to the south (Shervais and Hanan, 2008). Basalts that erupt within the transition zone between the MSL and CSL tend to have ${ }^{87} \mathrm{Sr}^{86} \mathrm{Sr}_{i}$ ratios ranging from 0.7040 to 0.7060 (Figure 4). The range in ${ }^{87} \mathrm{Sr} /{ }^{86} \mathrm{Sr}_{i}$ of those rocks is thought to reflect isotopic heterogeneities in 
source regions (Leeman and Whelan, 1983). Further west of the CSL, ${ }^{87} \mathrm{Sr}^{86} \mathrm{Sr}_{\mathrm{i}}$ ratios of most basalts are $<0.7040$ (Shervais and Hanan, 2008). Although understudied, sparse prior data on rhyolites in eastern Oregon indicate greater ${ }^{87} \mathrm{Sr} /{ }^{86} \mathrm{Sr}_{\mathrm{i}}$ than basalts in eastern Oregon (Figure 4; Savov et al., 2009). While both the Dinner Creek Tuff and Littlefield Rhyolite lie west of the MSL, they retain ${ }^{87} \mathrm{Sr} /{ }^{86} \mathrm{Sr}_{\mathrm{i}}=0.7066$ (Leeman et al., 1992). These data call into question the sharpness of the isotopic transitions between accreted terranes and craton.

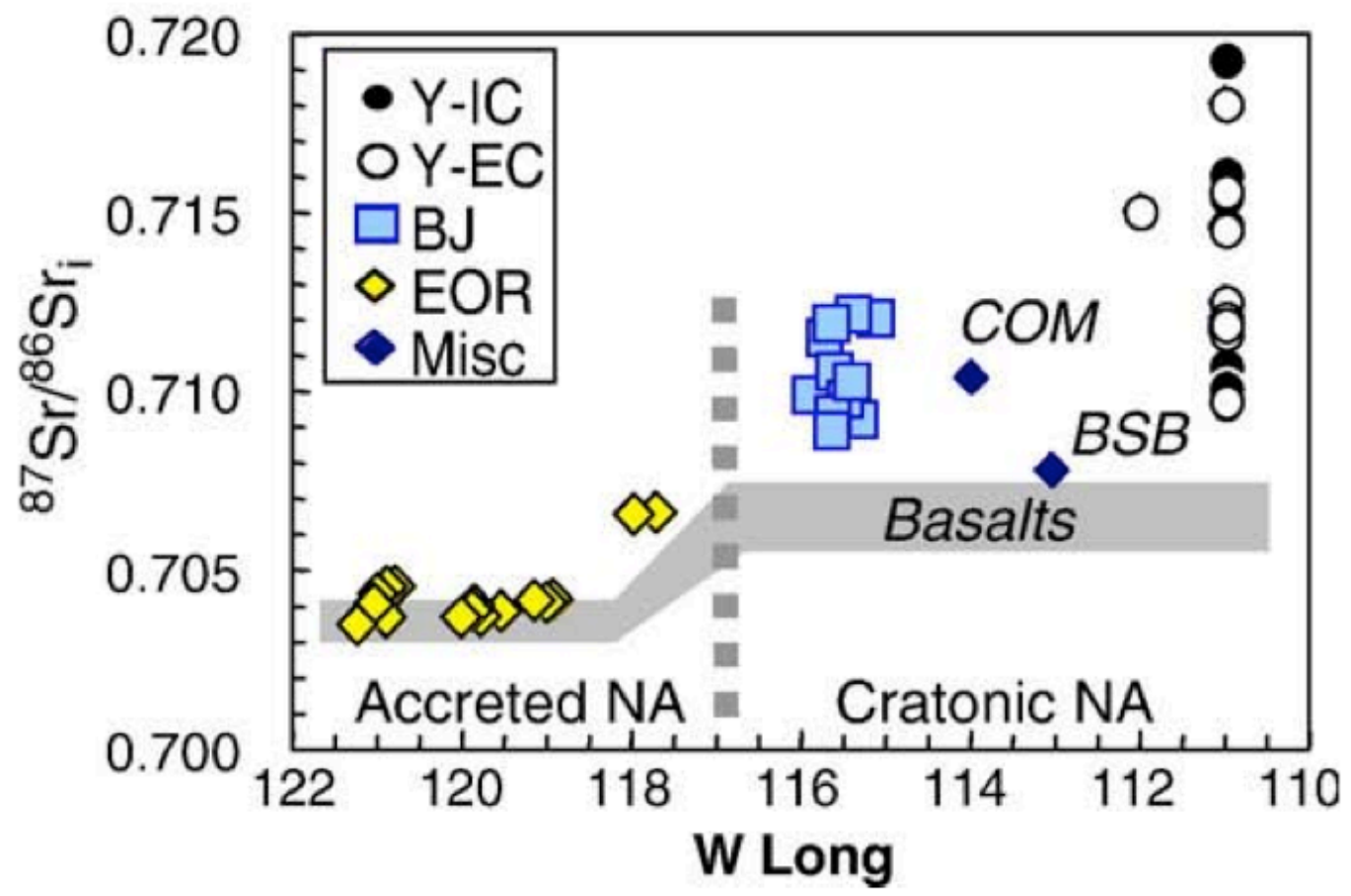

Figure 4. East-west variations in ${ }^{87} \mathrm{Sr}^{86}{ }^{8 \mathrm{Sr}_{\mathrm{i}}}$ of silicic volcanic rocks (Savov et al., 2009). Samples are: Yellowstone intracaldera (Y-IC) and extracaldera (Y-EC) rhyolites, Bruneau-Jarbridge (BJ) rhyolites, eastern Oregon (EOR) rhyolites; miscellaneous (Misc) samples include Craters of the Moon (COM) latite and Big Southern Butte (BSB) rhyolite. Vertical dashed line shows position of western Idaho suture zone (WISZ). Gray shading indicates compositional range for Neogene basalts from the High Lava Plain and Snake River Plain (after Savov et al., 2009).

While the map positions of the MSL and CSL are well-defined in the region between the Columbia River Plateau and Mesozoic Idaho Batholith in Idaho, the southern 
extension of the lines has diverse locations because of incomplete coverage of reference data (Hughes and McCurry, 2002). The original map by Armstrong et al. (1977) has a narrow CSL-MSL transition extending southward about $46^{\circ} \mathrm{N}$ into the Owyhee Plateau and then splitting near $43^{\circ} \mathrm{N}$, with the CSL continuing west-southwest to a widening CSL-MSL transition in northern Nevada (Figure 3). While the selection of samples is large throughout much of northern Oregon, there is sparse data between the $44.5^{\circ} \mathrm{N}$ to $42^{\circ} \mathrm{N}$ latitudes constraining the proposed contours. In contrast, Kistler and Peterman (1978) examined CSL and MSL strontium isotopic compositions of Mesozoic rocks in California, but their map varies slightly in that the separation of the CSL from the MSL is less gradual in southern Oregon and northern Nevada (Figure 5). Pierce and Morgan (1992) show a separation of the CSL-MSL lines at about $43^{\circ} \mathrm{N}$, with the CSL extending southwestward and the MSL extending southeastward based on geologic evidence (Figure 6). The Santa Rosa-Calico volcanic field lies between the two isopleths in the southern region, deflecting the MSL eastward approximately $200 \mathrm{~km}$ to the NevadaUtah-Idaho border (Pierce and Morgan, 1992). 


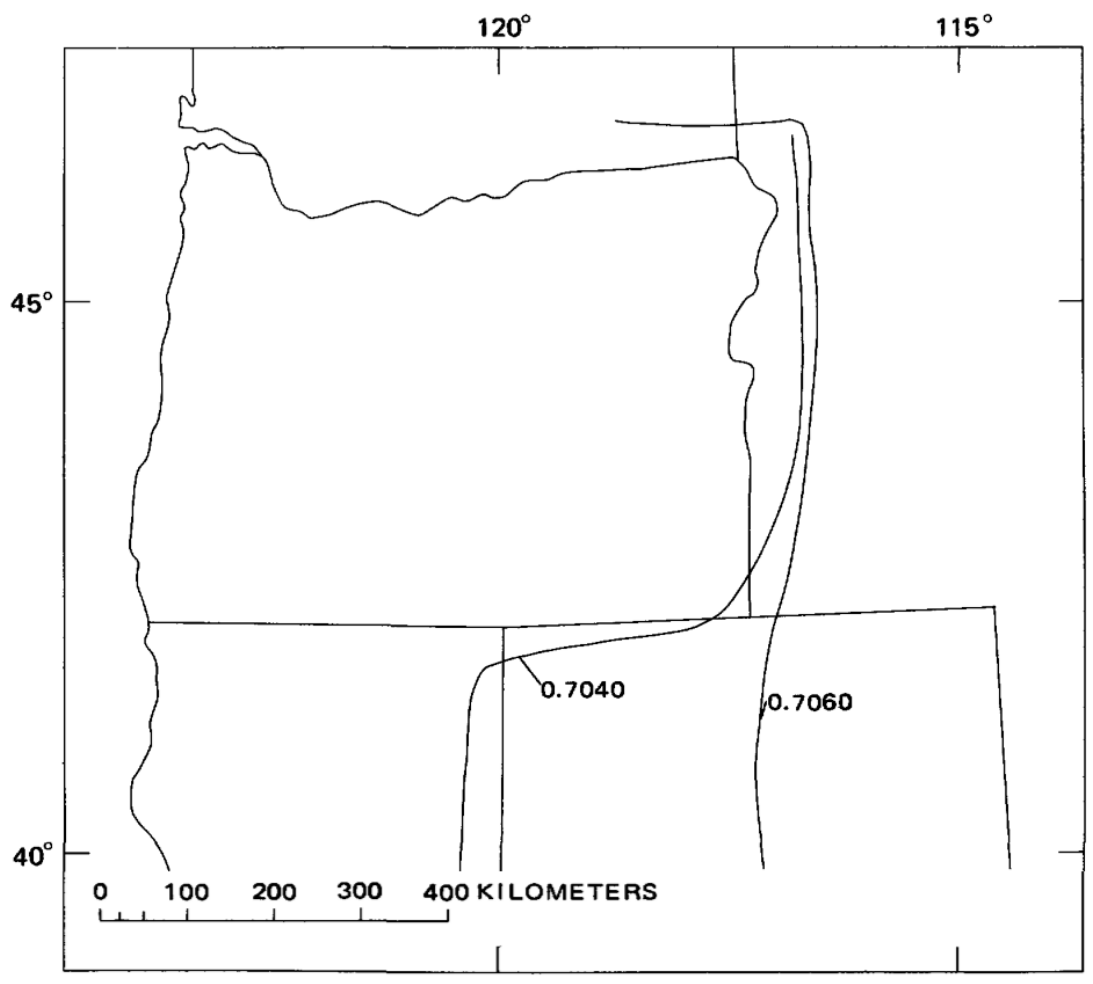

Figure 5. Location of CSL and MSL in western United States, from Kistler and Peterman (1978). 


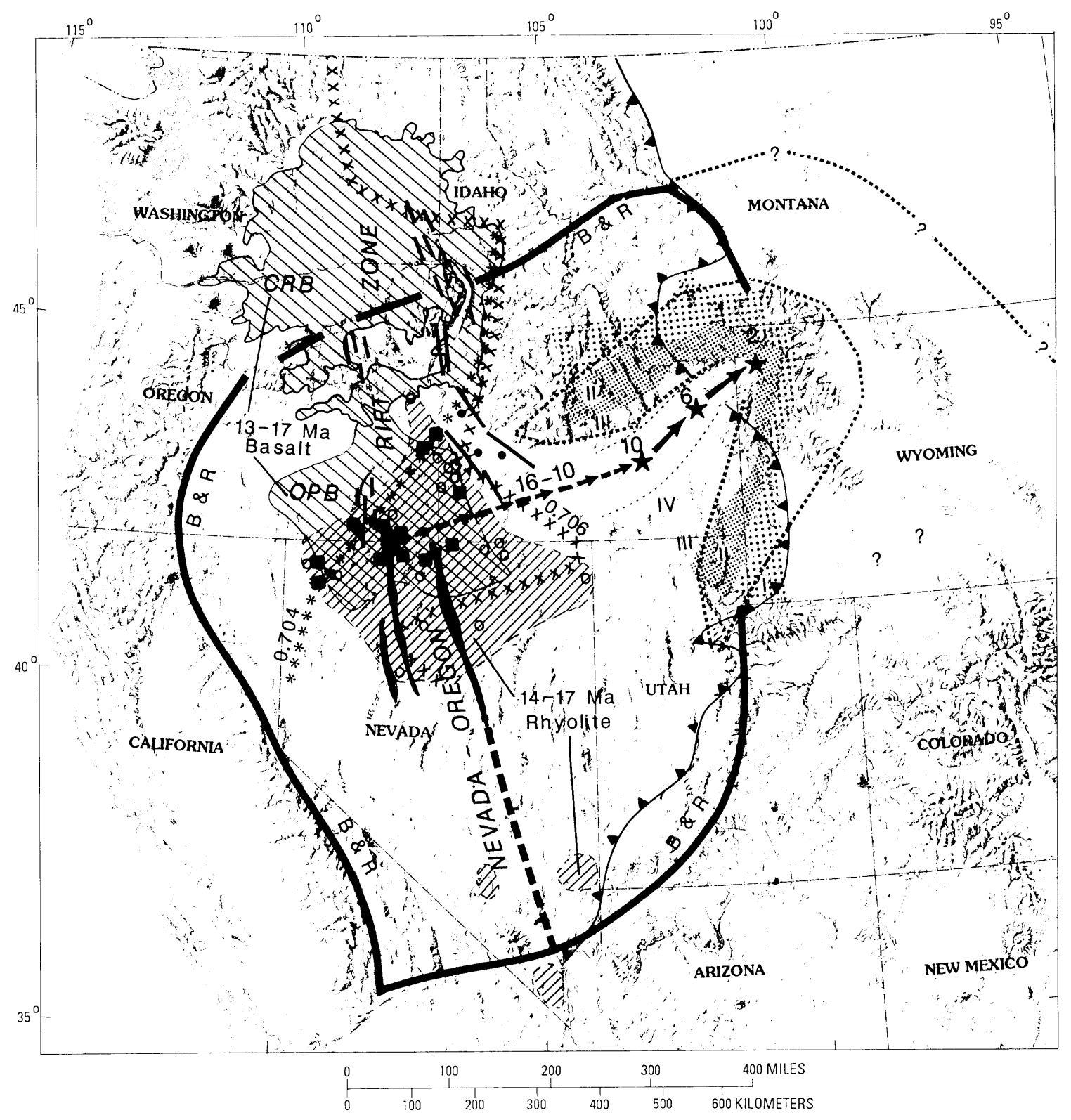

Figure 6. CSL (*), MSL (x), and other major geologic features in the western United States associated with the late Cenozoic track of the Yellowstone hot spot (Pierce and Morgan, 1992).

Leeman et al. (1992) describe the MSL coinciding with the western Idaho suture zone (WISZ), which is at the contact between western terrane rocks and Idaho Batholith plutonic rocks (Figure 7). They suggest the regional isotopic signatures define a narrow accretionary N-S suture zone about $116.5^{\circ} \mathrm{W}$ to $119^{\circ} \mathrm{W}$ that occurred along a westward- 
dipping decollement at lithospheric mantle depths during Rocky Mountain thrusting from 100-55 Ma (Leeman et al., 1992). The two overlapping sources that generated the transitional isotopic compositions in magmatism within the $\sim 150$-km-wide zone were accreted oceanic lithosphere and cratonic subcontinental mantle. Volcanic systems west of this zone were derived from accreted lithosphere with oceanic affinities while isotopic signatures east of this zone represent cratonic lower crust and subcontinental lithosphere (Leeman et al., 1992).
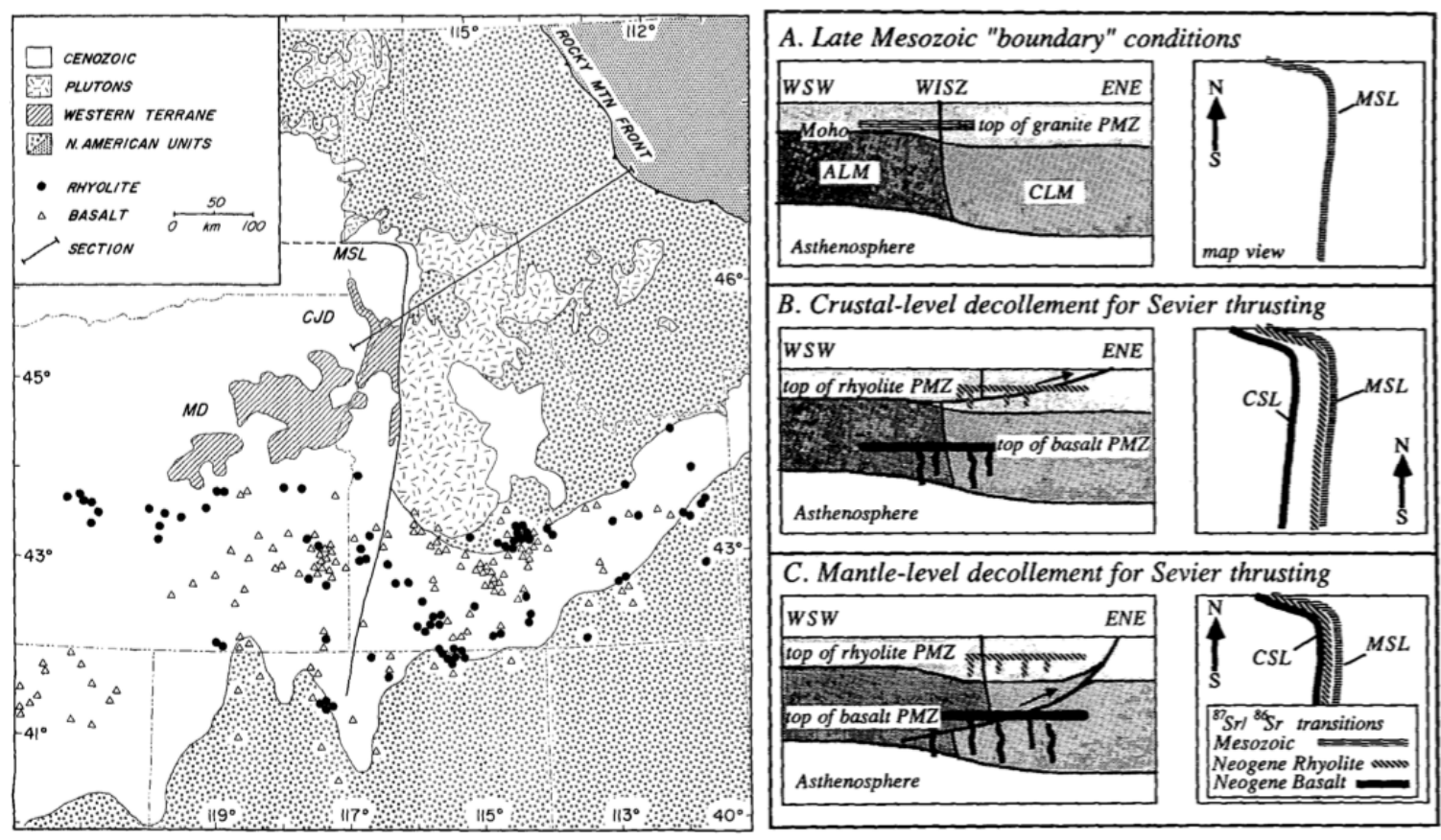

Figure 7. Map of northwestern United States showing the location of MSL and features associated with Cenozoic volcanism (left). Schematic lithospheric cross sections and ${ }^{87} \mathrm{Sr} /{ }^{86} \mathrm{Sr}$ isochrones from different events (right) (Leeman et al., 1992).

Fleck and Criss (2004) studied plutonic rocks and wall rock hosts in western Idaho and southeast Washington to establish a detailed characterization of isotopic variations across the terrane boundary between Precambrian crust and Late PaleozoicMesozoic island arc rocks. They delineate the WISZ by its juxtaposition of distinct rock 
types and its degree of deformation, as well as geochemical and isotopic variations in plutons emplaced within and into the two different crustal types (Figure 8). The WISZ coincides with the change in $\mathrm{Sr}$ and $\mathrm{Nd}$ initial-ratios across a narrow 5- to 15-km-wide zone (Fleck and Criss, 2004). An updated map by Pierce and Morgan (2009) has the separation between the CSL and MSL occurring further north at around $44^{\circ} \mathrm{N}$ with much less of an eastward trace of the MSL around the Nevada-Oregon-Idaho border (Figure 9). 
TOPO! map printed on 06/20/03 from "wisz fig 1.tpo" and "Untitled.tpg"

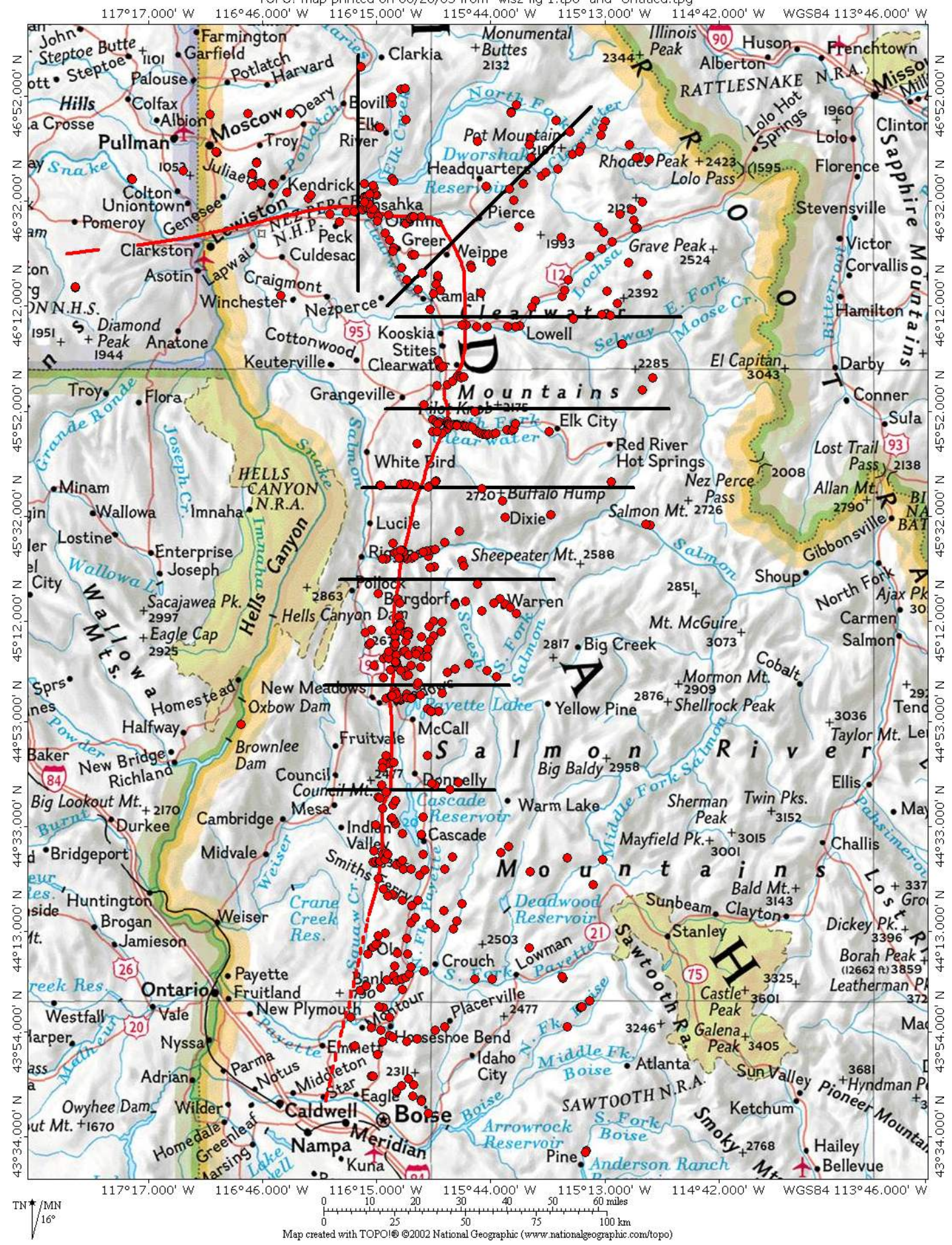

Figure 8. Map of the WISZ outlined in red. Red circles correspond to samples with Sr isotope data and black lines correspond to age traverses (Fleck and Criss, 2004). 


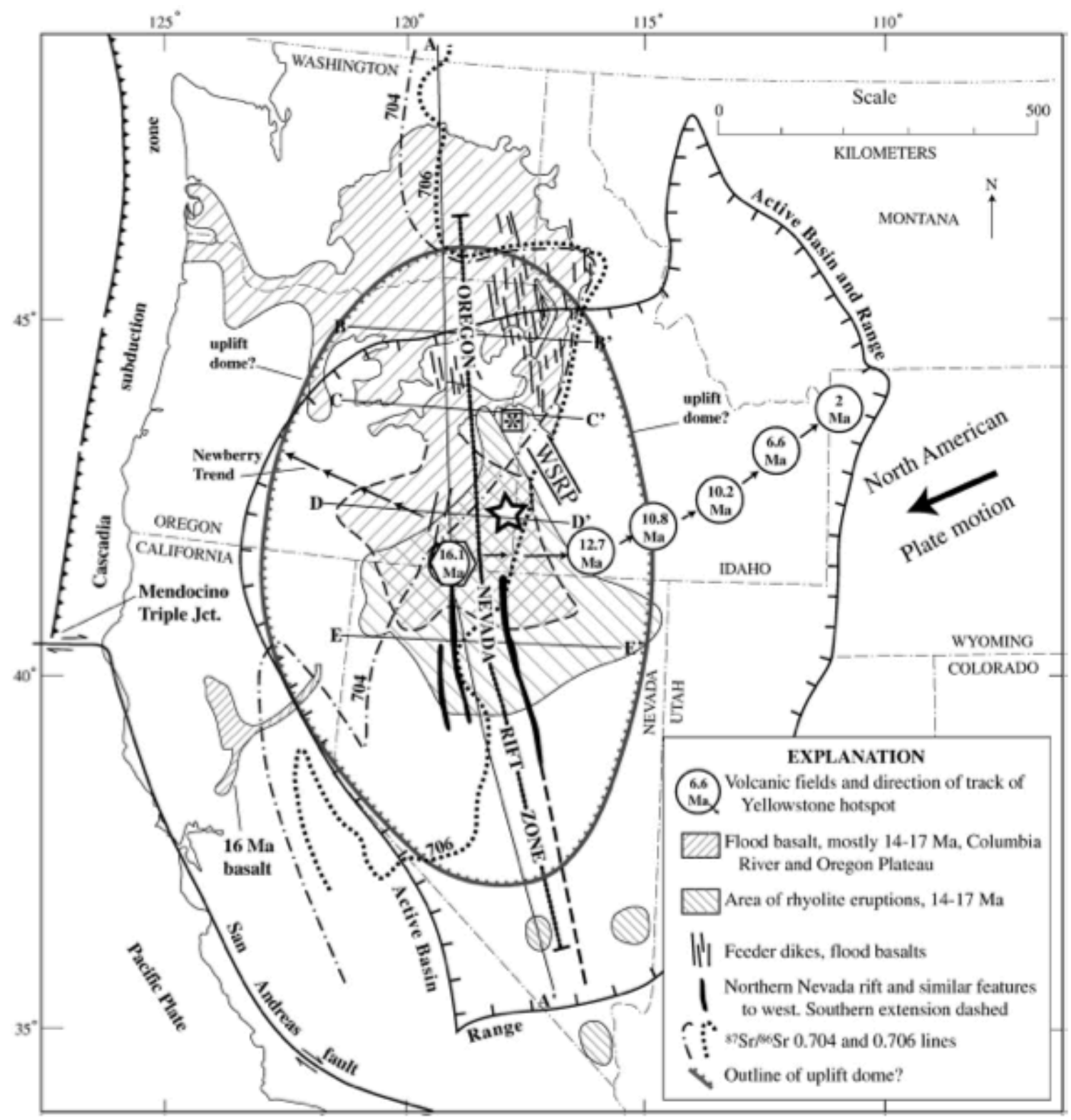

Figure 9. Map showing location of the Snake River-Yellowstone hot spot track and associated volcanism (Pierce and Morgan, 2009). The locations of the CSL (...) and MSL (...) lines are also shown. 


\section{Columbia River Basalt Province}

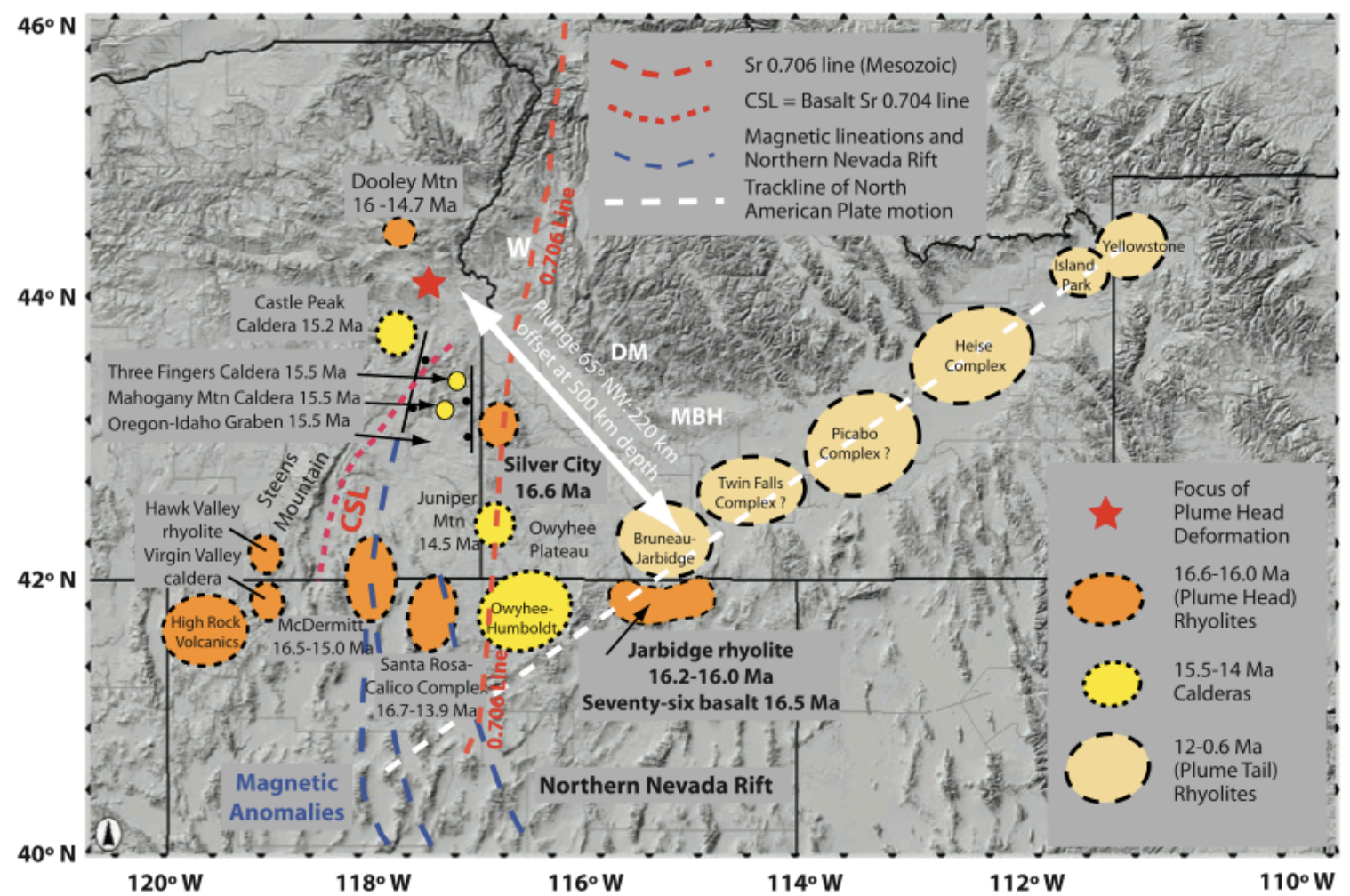

Figure 10. Map of digital topography of eastern Oregon, northern Nevada, and southern Idaho depicting eruptive complexes associated with the Snake River-Yellowstone hot spot track (Shervais and Hanan, 2008). The locations of the ${ }^{87} \mathrm{Sr} /{ }^{86} \mathrm{Sr}_{\mathrm{i}}=0.7040$ (CSL) and 0.7060 (MSL) lines are displayed.

Eruptive activity of all rhyolitic centers in this study is related to the continental Large Igneous Province (LIP) of the Columbia River Basalt-Yellowstone hotspot system. Most discussions regarding the origin of volcanism of the Columbia River Province have centered around a deep-seated mantle plume (Camp, 2013). At $17 \mathrm{Ma}$, a mantle plume incepted southeastern Oregon and generated Steens, Imnaha, and Grande Ronde lavas. These lavas erupted from vents associated with the Steens, Chief Joseph, and Monument dike swarms located in eastern Oregon and Washington from 16.8 to $15.5 \mathrm{Ma}$ (Barry et al., 2013). Silicic volcanism contemporaneous ( 16.5 Ma to $\sim 14.5 \mathrm{Ma})$ with this activity 
is widespread in Oregon, Nevada, and Idaho as voluminous flood basalt magmas induced partial melting in the crust and/or fractionated to produce rhyolites (Christiansen and Yeats, 1992; Cummings et al., 2000; Brueseke et al., 2008; Shervais and Hanan, 2008). A plume head-to-tail transition occurred from 14-10 Ma, as the plume head was decapitated by thick cratonic boundary due to the southwest-directed North American plate motion. The plume tail was fixed in the relatively stationary mantle (Pierce and Morgan, 2009). This tail, which is currently located beneath Yellowstone, left a track of eruptive complexes in the direction opposite to the overriding plate movement along the Snake River Plain (Figure 10; Shervais and Hanan, 2008).

\section{Silicic Volcanic Centers of this Study}

In total, twenty-seven silicic units were examined in this study. Prior knowledge regarding each of these units varies widely from just being described in an unpublished geologic map to being well characterized including chemical analyses, age dates, and isotope data. Rhyolites of this study were collected over a wide area in eastern Oregon, $200 \mathrm{~km}$ in the east-west dimension and $150 \mathrm{~km}$ in the north-south dimension. These rhyolites reflect volcanism of the northern to central sector of the rhyolite flare up of the Columbia River Basalt province (Figure 10). All samples are Miocene in age with the majority between 16 to 14 Ma. Published age determinations detailed in Table 1 fall in the range of 9.48 Ma (Circle Bar Rhyolite) to $22.8 \mathrm{Ma}$ (Dam Rhyolite, which has a more recently obtained age of $13.5 \mathrm{Ma})$. 
Table 1. Published radiometric age determinations for silicic centers associated with this study. Some units have several age determinations. Only the four most recent age dates are shown.

\begin{tabular}{|c|c|c|c|}
\hline Rock unit & Method & Age (Ma) & Reference \\
\hline Beulah Reservoir Trd & - & - & - \\
\hline \multirow[t]{2}{*}{ Buchanan Dome Complex } & $\mathrm{K} / \mathrm{Ar}$ & $15.1 \pm 0.5$ & Fiebelkorn et al. (1983) \\
\hline & $\mathrm{K} / \mathrm{Ar}$ & $13.9 \pm 0.9$ & Evans and Brown (1981) \\
\hline Circle Bar Rhyolite & $\mathrm{K} / \mathrm{Ar}$ & $9.48 \pm 0.3$ & Fiebelkorn et al. (1983) \\
\hline Dacite, Ironside Mountain & - & - & - \\
\hline \multirow[t]{2}{*}{ Dam Rhyolite } & $\mathrm{K} / \mathrm{Ar}$ & $22.8 \pm 2.6$ & Brown and Petros (1985) \\
\hline & $\mathrm{K} / \mathrm{Ar}$ & $13.5 \pm 3.4$ & Ferns and Cummings (1992) \\
\hline \multirow[t]{3}{*}{ Devine Canyon Tuff } & ${ }^{40} \mathrm{Ar} /{ }^{39} \mathrm{Ar}$ & $9.63 \pm 0.05$ & Ford (2011) \\
\hline & ${ }^{40} \mathrm{Ar} /{ }^{39} \mathrm{Ar}$ & $9.74 \pm 0.02$ & Jordan et al. (2004) \\
\hline & ${ }^{40} \mathrm{Ar} /{ }^{39} \mathrm{Ar}$ & $9.68 \pm 0.03$ & Streck et al. (1999) \\
\hline \multirow[t]{4}{*}{ Dinner Creek Ash-Flow Tuff } & ${ }^{40} \mathrm{Ar} /{ }^{39} \mathrm{Ar}$ & $15.1 \pm 2.0$ & Hooper et al. (2002) \\
\hline & ${ }^{40} \mathrm{Ar} /{ }^{39} \mathrm{Ar}$ & $15.4 \pm 0.6$ & Hooper et al. (2002) \\
\hline & ${ }^{40} \mathrm{Ar} /{ }^{39} \mathrm{Ar}$ & $15.38 \pm 0.17$ & Streck et al. (2011) \\
\hline & ${ }^{40} \mathrm{Ar} /{ }^{39} \mathrm{Ar}$ & $15.9 \pm 0.13$ & Streck et al. (2011) \\
\hline Donnelly Butte & - & - & - \\
\hline Dooley Mountain Rhyolite & $\mathrm{K} / \mathrm{Ar}$ & $14.7 \pm 0.4$ & Evans (1992) \\
\hline \multirow[t]{2}{*}{ Jump Creek Rhyolite } & $\mathrm{K} / \mathrm{Ar}$ & $10.6 \pm 0.3$ & Rytuba et al. (1991) \\
\hline & $\mathrm{K} / \mathrm{Ar}$ & $11.1 \pm 0.2$ & Armstrong et al. (1980) \\
\hline \multirow[t]{4}{*}{ Littlefield Rhyolite } & ${ }^{40} \mathrm{Ar} /{ }^{39} \mathrm{Ar}$ & $16.6 \pm 0.1$ & Hooper et al. (2002) \\
\hline & ${ }^{40} \mathrm{Ar} /{ }^{39} \mathrm{Ar}$ & $14.7 \pm 0.96$ & Lees (1994) \\
\hline & ${ }^{40} \mathrm{Ar} /{ }^{39} \mathrm{Ar}$ & $16.8 \pm 0.4$ & Lees (1994) \\
\hline & ${ }^{40} \mathrm{Ar} /{ }^{39} \mathrm{Ar}$ & $15.24 \pm 0.31$ & Lees (1994) \\
\hline McIntyre Ridge Rhyolite & $\mathrm{K} / \mathrm{Ar}$ & $15.8 \pm 0.6$ & Ekren et al. (1984) \\
\hline Rhyolite at Stockade Mountain & - & - & - \\
\hline Rhyolite of Bully Creek & - & - & - \\
\hline \multirow[t]{3}{*}{ Rhyolite of Cottonwood Mountain } & ${ }^{40} \mathrm{Ar} /{ }^{39} \mathrm{Ar}$ & $15.5 \pm 0.7$ & Hooper et al. (2002) \\
\hline & ${ }^{40} \mathrm{Ar} /{ }^{39} \mathrm{Ar}$ & $15.7 \pm 0.2$ & Hooper et al. (2002) \\
\hline & ${ }^{40} \mathrm{Ar} /{ }^{39} \mathrm{Ar}$ & $14.6 \pm 1.0$ & Hooper et al. (2002) \\
\hline \multirow[t]{4}{*}{ Spring Creek Tuff } & $\mathrm{K} / \mathrm{Ar}$ & 15.4 & Rytuba and VanderMeulen (1991) \\
\hline & ${ }^{40} \mathrm{Ar} /{ }^{39} \mathrm{Ar}$ & $15.95 \pm 0.06$ & Benson et al. (2013) \\
\hline & ${ }^{40} \mathrm{Ar} /{ }^{39} \mathrm{Ar}$ & $15.4 \pm 0.2$ & Hooper et al. (2002) \\
\hline & ${ }^{40} \mathrm{Ar} /{ }^{39} \mathrm{Ar}$ & $15.64 \pm 0.09$ & Marcy et al. (2013) \\
\hline \multirow[t]{3}{*}{ Strawberry Mountain Volcanics } & $\mathrm{K} / \mathrm{Ar}$ & $12.5 \pm 0.4$ & Walker et al. (1974) \\
\hline & $\mathrm{K} / \mathrm{Ar}$ & $12.2 \pm 0.4$ & Walker et al. (1974) \\
\hline & $\mathrm{K} / \mathrm{Ar}$ & $17.3 \pm 0.36$ & Fiebelkorn et al. (1983) \\
\hline \multirow[t]{2}{*}{ Swamp Creek Rhyolite } & $\mathrm{K} / \mathrm{Ar}$ & $15.7 \pm 0.3$ & Fiebelkorn et al. (1983) \\
\hline & $\mathrm{K} / \mathrm{Ar}$ & $16.1 \pm 0.3$ & Fiebelkorn et al. (1983) \\
\hline Three Fingers Intra-caldera Rhyolite & ${ }^{40} \mathrm{Ar} /{ }^{39} \mathrm{Ar}$ & $15.64 \pm 0.08$ & Marcy et al. (2013) \\
\hline Trd North of Drewsey & - & - & - \\
\hline Trd South of Drewsey & - & - & - \\
\hline \multirow[t]{3}{*}{ Tuff, North of Unity } & ${ }^{40} \mathrm{Ar} /{ }^{39} \mathrm{Ar}$ & $16.45 \pm 0.14$ & Streck et al. (2011) \\
\hline & $\mathrm{K} / \mathrm{Ar}$ & $19.6 \pm 0.8$ & Fiebelkorn et al. (1983) \\
\hline & $\mathrm{K} / \mathrm{Ar}$ & $19.5 \pm 0.6$ & Fiebelkorn et al. (1983) \\
\hline
\end{tabular}


Many samples are rhyolites belonging to the Lake Owyhee Volcanic Field (LOVF) (Cummings et al., 2000; Ferns and McClaughry, 2013). These are nearly cospatial with the presumed topographic uplift associated with the thermal anomaly of the Columbia River province (Pierce and Morgan, 2009), as well as with the convergence zone of CRBG dikes, aeromagnetic anomalies and other large-scale features.

\section{${ }^{87} \mathrm{Rb}-{ }^{87} \mathrm{Sr}$ Decay, the ${ }^{87} \mathrm{Sr} /{ }^{86} \mathrm{Sr}$ Isotope System, and the MSL and CSL}

${ }^{87} \mathrm{Rb}$ naturally decays to ${ }^{87} \mathrm{Sr}$ by beta emission with a half-life of $4.88 \times 10^{10}$ years (Faure and Mensing, 2005). Because rubidium substitutes for $\mathrm{K}^{+}$in potassium-bearing minerals, the principal carriers of rubidium are biotite, muscovite, lepidolite, orthoclase, and microcline (Faure and Powell, 1972). Igneous processes generally concentrate rubidium in the residual magma relative to potassium. Strontium, which substitutes for $\mathrm{Ca}^{2+}$ in calcium-bearing minerals, is mostly incorporated into plagioclase feldspar, apatite, clinopyroxene, and hornblende. The strontium concentration decreases with increasing degree of fractionation of the magma because it is removed from the liquid phase and is concentrated primarily in early-formed calcic plagioclase (Faure and Powell, 1972). The ${ }^{87} \mathrm{Sr} /{ }^{86} \mathrm{Sr}_{\mathrm{i}}$, and how much ${ }^{87} \mathrm{Rb}$ decays to ${ }^{87} \mathrm{Sr}$, depends on the $\mathrm{Rb} / \mathrm{Sr}$ ratio of the sample and on the amount of time it has had to decay (Faure and Powell, 1972). The ${ }^{87} \mathrm{Sr} /{ }^{86} \mathrm{Sr}_{\mathrm{i}}$ ratio in the crust increases more rapidly than the mantle because the $\mathrm{Rb} / \mathrm{Sr}$ ratio of the continental crust is five to ten times greater than the $\mathrm{Rb} / \mathrm{Sr}$ ratio in the upper mantle (McDougall, 1976). Magmas generated in the continental crust are expected to have a higher ${ }^{87} \mathrm{Sr} /{ }^{86} \mathrm{Sr}_{\mathrm{i}}$ ratio than those generated in the asthenospheric mantle. 
The MSL that separates cratonic crust to the east and the accreted lithosphere of oceanic affinity to the west displays this relationship with igneous rocks east of the line generally having higher ratios (Shervais and Hanan, 2008). The CSL that runs southwest from Idaho through Oregon was placed using basalts and intrusive rocks to determine its location. Data are lacking to establish a ${ }^{87} \mathrm{Sr}^{86} \mathrm{Sr}_{\mathrm{i}}$ relationship using rhyolites.

Furthermore, the issue of what ${ }^{87} \mathrm{Sr} /{ }^{86} \mathrm{Sr}_{\mathrm{i}}$ of basalts versus rhyolites means has not been sufficiently addressed. If basalts do not interact with crust, they should record a mantle value. Yet, if partial melting of the crust produces the rhyolites, they record a crustal value. Often there is coherence between the results of basalt and rhyolite. This correlation may result from the mantle under accreted terrane being depleted with time giving rise to lower ${ }^{87} \mathrm{Sr} /{ }^{86} \mathrm{Sr}_{\mathrm{i}}$ in the basalt or the mantle under the craton is enriched giving rise to higher ${ }^{87} \mathrm{Sr} /{ }^{86} \mathrm{Sr}_{\mathrm{i}}$. A separate signal may be the rhyolites recording a depleted accreted terrane crustal melt because it has an overall lower ${ }^{87} \mathrm{Sr} /{ }^{86} \mathrm{Sr}_{\mathrm{i}}$ ratio. 


\section{METHODS}

\section{Sample Collection}

Samples were collected from outcrops in eastern Oregon using published geologic maps, field guides, and unpublished location information. Coordinates of sample locations were recorded by GPS. In total, thirty-three samples from twenty-two silicic units were collected for this study (Figure 11, Table 2). Detailed sample descriptions can be found in Appendix A. Sampled lithologies are ash-flow tuffs, rhyolite dome rocks, and silicic lava flows.

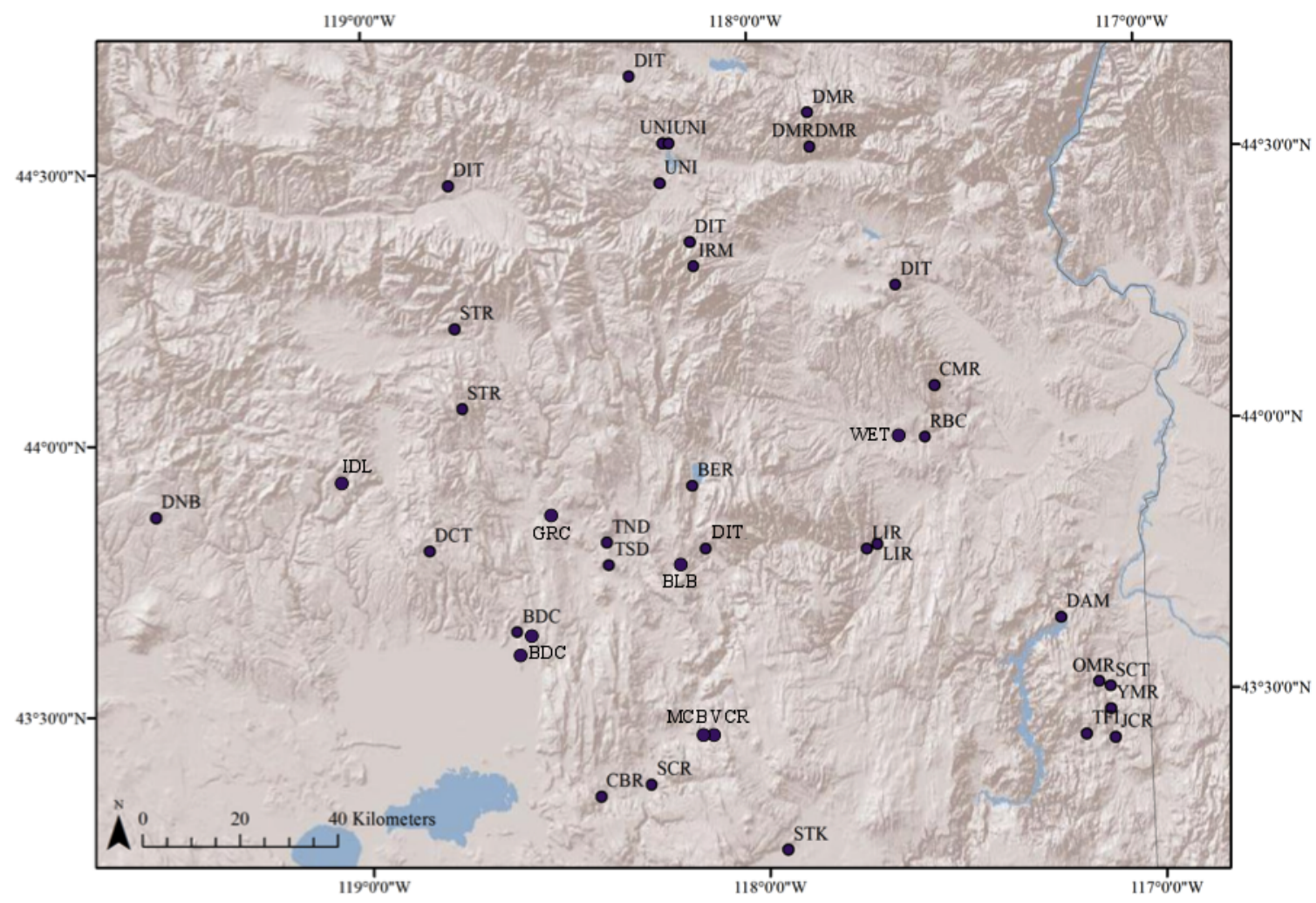

Figure 11. Location map for all samples collected for this study. 
Table 2. Unit assignments and locations for each sample in this study. Latitude and longitude are listed in decimal degrees. The inferred source location for Dinner Creek Tuff is $44.04^{\circ} \mathrm{N}, 118.17^{\circ} \mathrm{W}$ and the inferred source location for Devine Canyon Tuff is $43.55^{\circ} \mathrm{N}, 118.78^{\circ} \mathrm{W}$.

\begin{tabular}{|c|c|c|c|c|}
\hline Sample ID & Unit ID & Unit & Latitude & Longitude \\
\hline EJ-12-01 & DNB & Donnelly Butte & 43.8678 & -119.5415 \\
\hline EJ-12-02 & DNB & Donnelly Butte & 43.8595 & -119.5371 \\
\hline EJ-12-03 & $\mathrm{BDC}$ & Buchanan Dome Complex & 43.6453 & -118.6258 \\
\hline EJ-12-04 & $\mathrm{BDC}$ & Buchanan Dome Complex & 43.5922 & -118.6231 \\
\hline EJ-12-05A & CBR & Circle Bar Rhyolite & 43.3389 & -118.4225 \\
\hline EJ-12-05B & CBR & Circle Bar Rhyolite & 43.3389 & -118.4225 \\
\hline EJ-12-06A & SCR & Swamp Creek Rhyolite & 43.3585 & -118.2938 \\
\hline EJ-12-06B & SCR & Swamp Creek Rhyolite & 43.3585 & -118.2957 \\
\hline EJ-12-07 & BER & Beulah Reservoir Trd & 43.9074 & -118.1704 \\
\hline EJ-12-08 & DIT & Dinner Creek Tuff & 43.7905 & -118.1408 \\
\hline EJ-12-09 & LIR & Littlefield Rhyolite (upper) & 43.7817 & -117.6906 \\
\hline EJ-12-10 & LIR & Littlefield Rhyolite (upper) & 43.7897 & -117.7023 \\
\hline EJ-12-11 & OMR & Old McIntyre Ridge Rhyolite & 43.5177 & -117.1515 \\
\hline EJ-12-12 & OMR & Old McIntyre Ridge Rhyolite & 43.5213 & -117.1518 \\
\hline EJ-12-13A & JCR & Jump Creek Rhyolite & 43.4178 & -117.1162 \\
\hline EJ-12-13B & $\mathrm{JCR}$ & Jump Creek Rhyolite & 43.4178 & -117.1162 \\
\hline EJ-12-14 & YMR & Young McIntyre Ridge Rhyolite & 43.4708 & -117.1242 \\
\hline EJ-12-15 & DAM & Dam Rhyolite & 43.6428 & -117.2417 \\
\hline EJ-12-16 & CMR & Rhyolite of Cottonwood Mountain & 44.0786 & -117.5433 \\
\hline EJ-12-17 & $\mathrm{RBC}$ & Rhyolite of Bully Creek & 43.9837 & -117.5720 \\
\hline EJ-12-18 & WET & Westfall Tvr & 43.9814 & -117.6396 \\
\hline EJ-12-19 & TSD & Trd South of Drewsey & 43.7652 & -118.3884 \\
\hline EJ-12-20 & TND & Trd North of Drewsey & 43.8067 & -118.3923 \\
\hline EJ-12-21A & GRC & Griffen Creek Rhyolite & 43.8562 & -118.5354 \\
\hline EJ-12-21B & GRC & Griffen Creek Rhyolite & 43.8562 & -118.5354 \\
\hline EJ-12-22A & IRM & Dacite, NE Flank Ironside Mountain & 44.3122 & -118.1513 \\
\hline EJ-12-22B & IRM & Dacite, NE Flank Ironside Mountain & 44.3122 & -118.1513 \\
\hline EJ-12-23A & DMR & Dooley Mountain Rhyolite & 44.5260 & -117.8430 \\
\hline EJ-12-23B & DMR & Dooley Mountain Rhyolite & 44.5260 & -117.8430 \\
\hline CR-U3A & UNI & Rhyolite lava flow, North of Unity & 44.5404 & -118.2218 \\
\hline CR-U4B & UNI & Tuff, North of Unity & 44.5397 & -118.2065 \\
\hline MS-12-14b & UNI & Rhyolite lava flow, West of Unity & 44.4666 & -118.2330 \\
\hline CR-U35a & DIT & Dinner Creek Tuff & 44.3567 & -118.1595 \\
\hline MS-PCIT 1-A & DIT & Dinner Creek Tuff & 44.4709 & -118.7787 \\
\hline MS-12-29.1 & DIT & Dinner Creek Tuff & 44.2665 & -117.6339 \\
\hline MS-11-20 & DIT & Dinner Creek Tuff & 44.6650 & -118.3051 \\
\hline AS-SV-151 & STR & Strawberry Mountain Rhyolite & 44.0591 & -118.7539 \\
\hline AS-SV-190 & STR & Strawberry Mountain Rhyolite & 44.2071 & -118.7689 \\
\hline AS-SV-243 & DCT & Devine Canyon Tuff & 43.7978 & -118.8447 \\
\hline MS-08-DR2 & DMR & Dooley Mountain Rhyolite & 44.5893 & -117.8466 \\
\hline MS-LFR1 & LIR & Littlefield Rhyolite (lower) & 43.7816 & -117.7298 \\
\hline MS-11-45 & STK & Rhyolite at Stockade Mountain & 43.2313 & -117.9533 \\
\hline MS-11-15 & SCT & Spring Creek Tuff & 43.5120 & -117.1235 \\
\hline TF-88A & TFI & Three Fingers Intra-caldera Rhyolite & 43.4259 & -117.1888 \\
\hline MS-13-12 & BLB & Black Butte Rhyolite & 43.7558 & -118.2097 \\
\hline
\end{tabular}




\begin{tabular}{ccccc} 
MS-13-09 & MCB & McEwen Butte Rhyolite & 43.4394 & -118.1481 \\
MS-13-10 & VCR & Visher Creek Rhyolite & 43.4367 & -118.1455 \\
MS-13-05 & IDL & Rhyolite West of Idlewild & 43.9267 & -119.0739 \\
AL-13-015b & BDC & Obsidian near Buchanan Dome Complex & 43.6328 & -118.6051 \\
\hline
\end{tabular}

\section{Analytical Methods}

\section{Thin Section and Petrographic Analyses}

Petrographic characteristics of samples were determined using plane- and crossed-polarized transmitted light. Features from thin section analyses include mineral occurrences, sizes, and proportions, as well as mineral and rock textures (Appendix A).

\section{Chemical Data}

Major and trace element analyses were performed at the GeoAnalytical Lab at Washington State University using X-ray fluorescence (XRF) and inductively coupled plasma-mass spectrometry (ICP-MS). Detailed methods and data can be found in Appendix B.

\section{Radiogenic Isotopes}

To prepare for isotopic analyses, single crystals were etched in $10 \% \mathrm{HF}$ to remove surface contaminants. Both crystals and whole rock samples were digested using a series of acids ( $\mathrm{HF}, \mathrm{HCl}$, and $\mathrm{HNO}_{3}$ ) over a three-day period. Cation and anion exchange chromatography was used to purify $\mathrm{Sr}$ and $\mathrm{Pb}$ from dissolved samples. Sr isotopic analyses were performed on whole rock and feldspar crystals at New Mexico State University (NMSU) using thermal ionization mass spectrometry (TIMS). For samples 
with $\mathrm{Sr}$ concentrations less than $15 \mathrm{ppm}$ as measured by ICP-MS, $\mathrm{Sr}$ and $\mathrm{Rb}$ concentrations for feldspars and groundmass were determined by isotope dilution using a high $\mathrm{Rb} / \mathrm{Sr}$ spike. $\mathrm{Pb}$ isotopic analyses were performed on whole rock samples at University of Wyoming using multicollector inductively coupled plasma mass spectrometry (MC-ICP-MS). Detailed radiogenic isotopic methods can be found in Appendix C.

\section{Stable Isotopes}

Oxygen isotope analyses were performed on bulk samples of quartz, plagioclase, alkali feldspar, and glass at University of Oregon. Oxygen was separated from the crystals using laser fluorination and a 35W Newwave $\mathrm{CO}_{2}$ IR laser. A Finnigan MAT 253 , large radius $10 \mathrm{kv}$ gas source mass spectrometer was used for the final oxygen gas analysis. This method yielded particularly precise values with an error of better than $\pm 0.1 \%$, 1 standard deviation. Results from the bulk crystal analyses can be used to calculate a bulk rock $\delta^{18} \mathrm{O}$ value (Bindeman and Valley, 2002, 2003; Bindeman et al., 2004). Detailed oxygen isotopic methods and further calculations can be found in Appendix D.

Age Determinations

Feldspar phenocrysts or groundmass were selected from fresh samples for

${ }^{40} \mathrm{Ar} /{ }^{39} \mathrm{Ar}$ dating at the Oregon State University (OSU) ${ }^{40} \mathrm{Ar} /{ }^{39} \mathrm{Ar}$ Geochronology 
Laboratory. Detailed ${ }^{40} \mathrm{Ar} /{ }^{39} \mathrm{Ar}$ incremental heating methods and age plateaus can be found in Appendix E. 


\section{RESULTS}

\section{Petrography}

Rhyolitic ignimbrites and lava flows examined in thin section fall evenly into three categories of aphyric, phenocryst poor $(<6 \%)$, and moderately porphyritic $(7 \%$ $25 \%$ phenocrysts). Textures include flow banded, vitroclastic, and hyalopilitic. Three samples from the Owyhee region exhibited concentric fractures indicating perlitic texture, which is common to rhyolites after the glass rehydrates. The most prevalent mineral phase among the samples was plagioclase, which ranges from $0-30 \%$ by volume. Also present to a lesser degree was sanidine, quartz, pyroxenes, Fe-Ti oxides, and sparse biotite and amphibole instead of pyroxene. A detailed petrographic examination of the samples is displayed in Table 7.

\section{Whole Rock Chemistry}

Of the total number of rocks collected, thirty-seven samples were analyzed for major and trace elements (Table 8). Weight percent $\mathrm{SiO}_{2}$ ranges from $64 \%$ to $78 \%$ and total alkali contents range from 5.7\% to $9.2 \%$. With the exception of EJ-12-22B (Ironside Mountain dacite) and MS-11-20 (Dinner Creek Tuff), all samples are categorized as rhyolite using total alkali versus silica (Figure 12). MS-11-20 is a mingled bulk tuff sample of the Dinner Creek Tuff consisting of high-silica rhyolite and less silicic components. Rhyolites are compositionally diverse ranging from low to high-silica rhyolites (Figure 12). With the exception of AS-SV-243 (Devine Canyon Tuff), which is classified as peralkaline, samples are metaluminous to slightly peraluminous, indicating 
alumina saturation (ie. $\mathrm{Al}_{2} \mathrm{O}_{3} /\left(\mathrm{Na}_{2} \mathrm{O}+\mathrm{K}_{2} \mathrm{O}\right)$ and $\mathrm{Al}_{2} \mathrm{O}_{3} /\left(\mathrm{CaO}+\mathrm{Na}_{2} \mathrm{O}+\mathrm{K}_{2} \mathrm{O}\right)$ are around 1 , Figure 13). Both calcium and iron follow the expected trend of a systematic depletion as silica increases (Figure 14 and Figure 15).

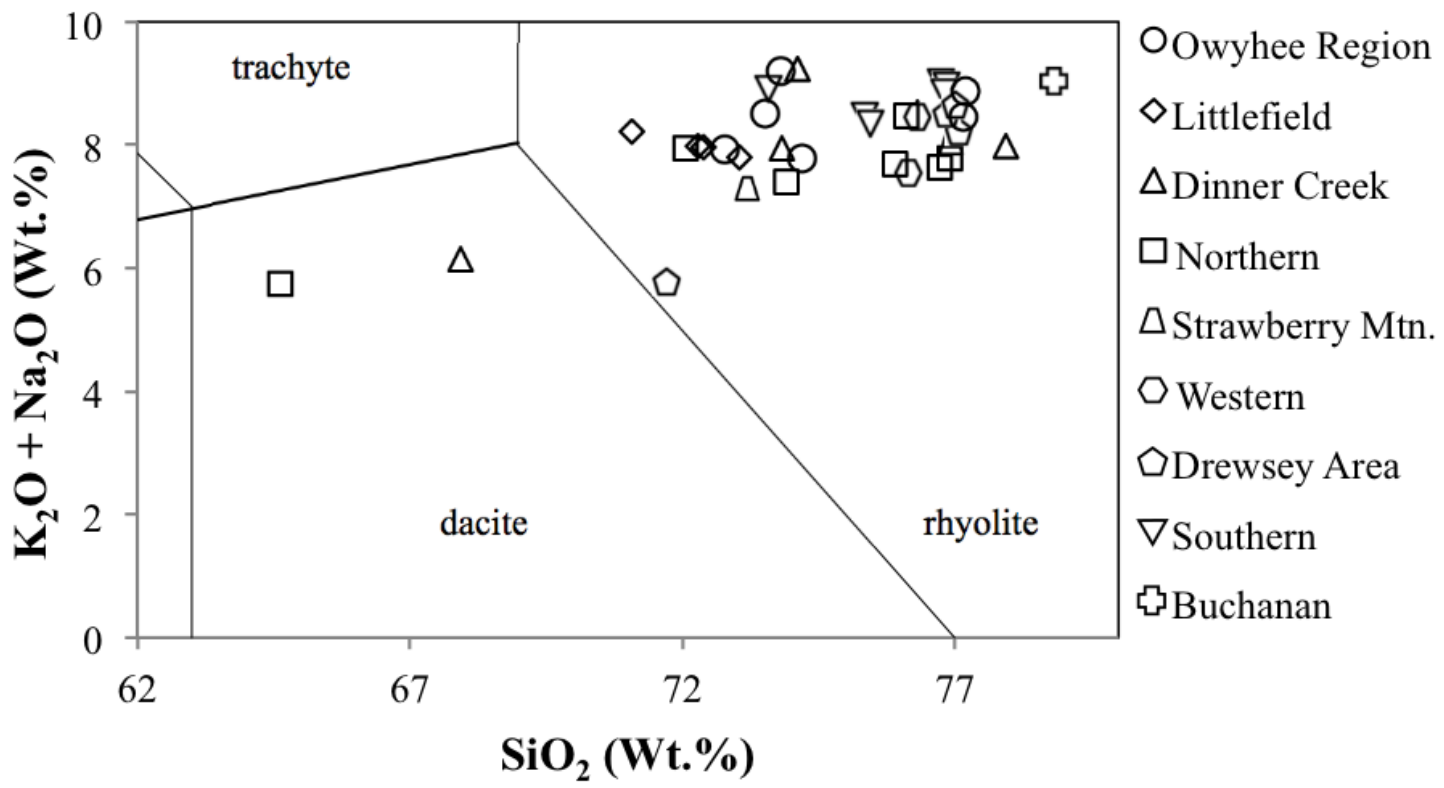

Figure 12. Total alkali-silica diagram for samples of this study (Le Bas, 1986). All but two samples are classified as rhyolite.

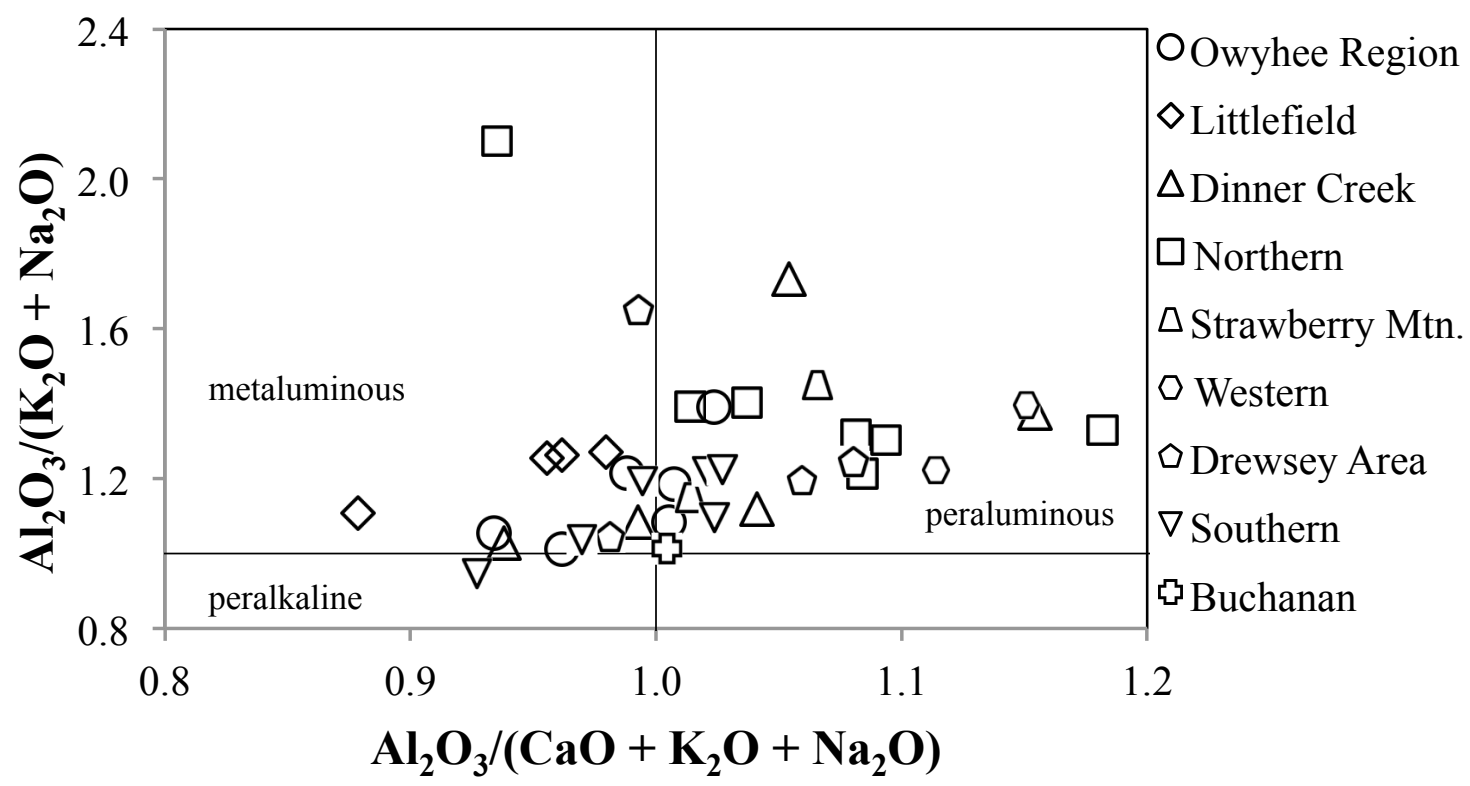

Figure 13. Molar A/NK versus $A / C N K$ (Maniar and Piccoli, 1989) for samples; one sample falls in the peralkaline field while the remainder are in the metaluminous and the peraluminous fields. 


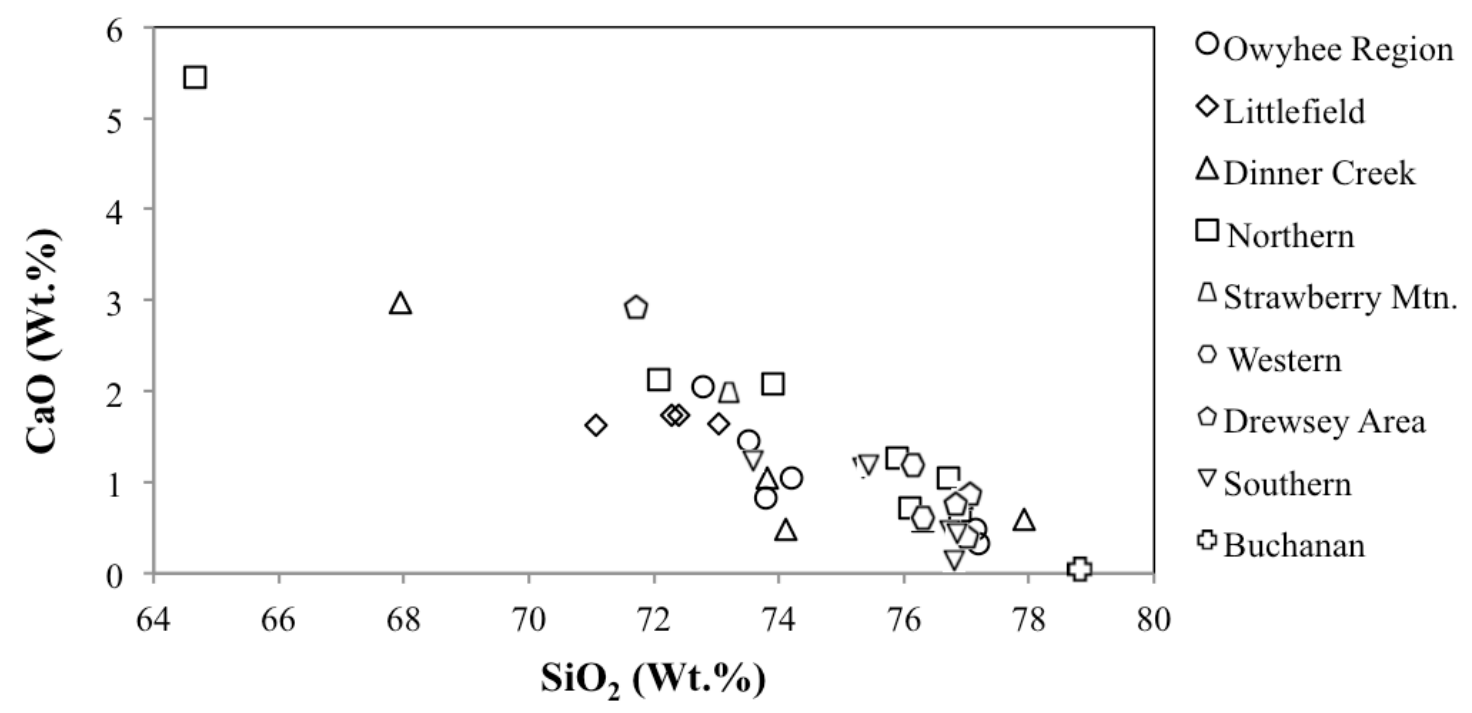

Figure 14. Diagram illustrating $\mathrm{CaO}$ versus $\mathrm{SiO}_{2}$. Overall calcium contents decline with increasing silica contents. Samples from the western and southern transect have less calcium than Littlefield Rhyolite and samples from the northern transect, likely because they tend to have a higher silica content.

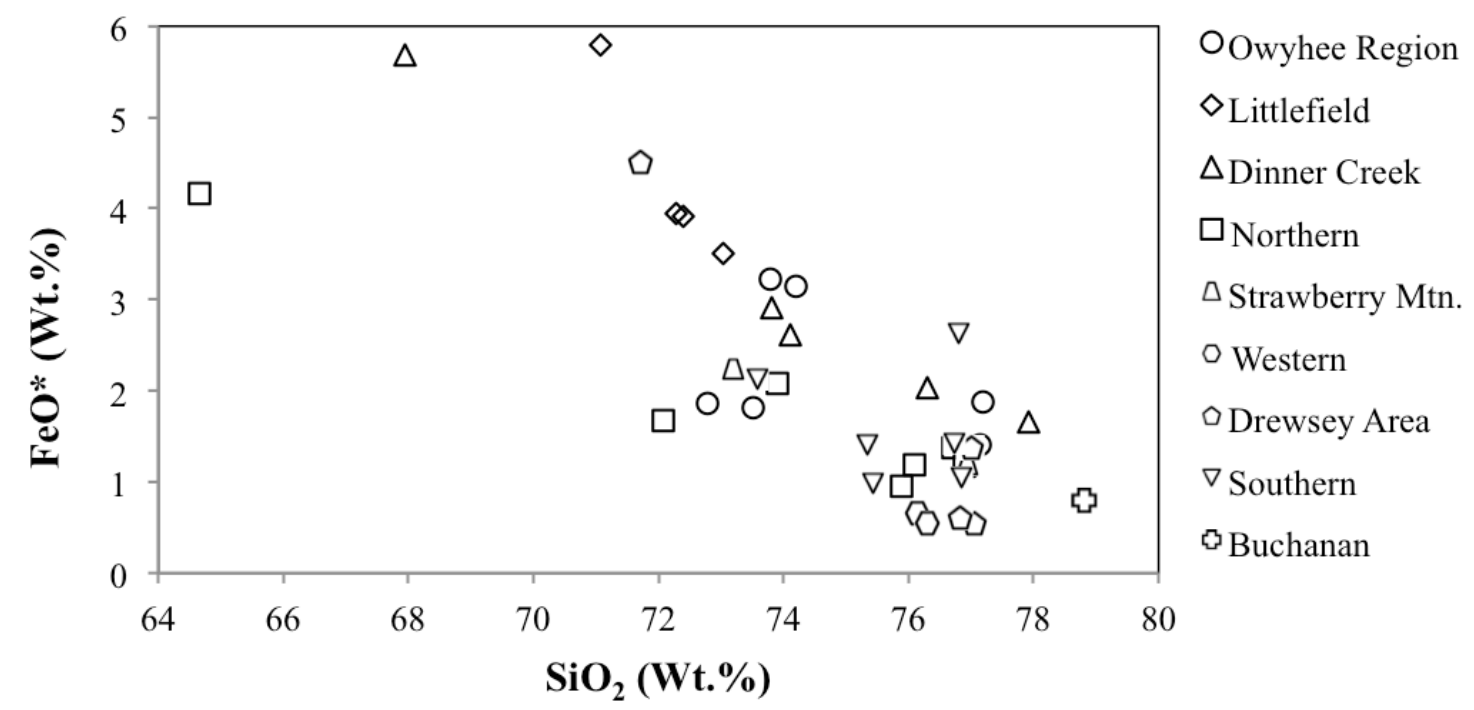

Figure 15. Diagram illustrating $\mathrm{FeO}^{*}$ versus $\mathrm{SiO}_{2}$. Overall $\mathrm{FeO}^{*}$ content declines with increasing silica, following the same trend as calcium (Figure 14).

According to the discrimination system of Whalen et al. (1987), the majority of the rhyolites (21) in this study show major and trace element chemistry similar to A-type granites and rhyolites, while 16 are similar to I-type granites and rhyolites (Figure 16). Although compositions of A-type rhyolites are diverse in regards to degree of 
fractionation and contents of incompatible trace element concentrations, they can usually be distinguished from I-type rhyolites by higher $\mathrm{Ba} / \mathrm{Sr}$, lower $\mathrm{La} / \mathrm{Yb}$, and generally higher high field strength elements (HFSE) and heavy rare earth elements (HREE) abundances. The typical rock association for A-type rhyolites in a continental setting are bimodal provinces or flood basalt provinces while I-type rhyolites are typically associated with calc-alkaline volcanic suites in volcanic arc and intra-continental settings (Streck and Grunder, 2008).

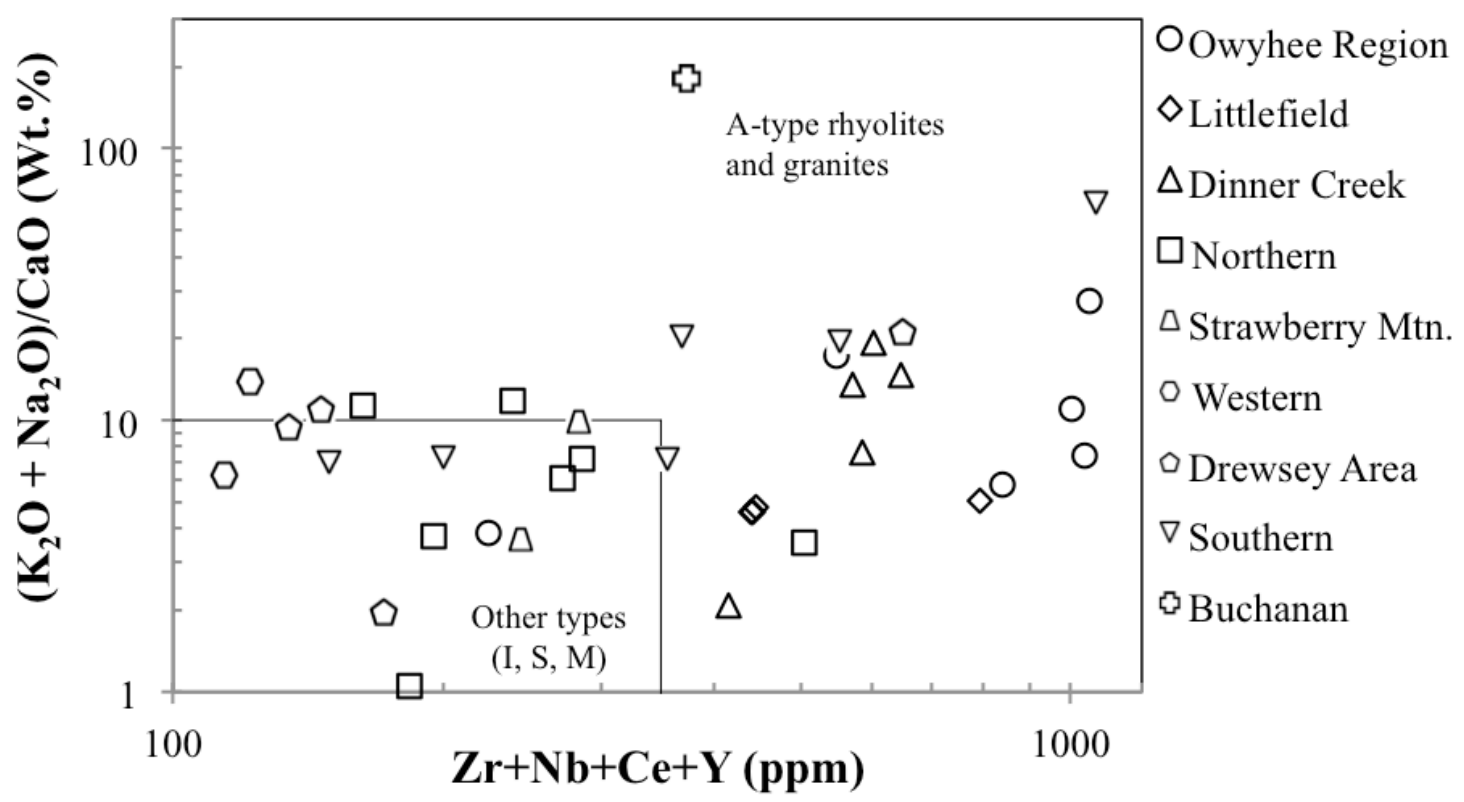

Figure 16. $\left(\mathrm{K}_{2} \mathrm{O}+\mathrm{Na}_{2} \mathrm{O}\right) / \mathrm{CaO}$ versus $\mathrm{Zr}+\mathrm{Nb}+\mathrm{Ce}+\mathrm{Y}$ diagram to differentiate A-type granites and rhyolites from other types of granites and rhyolites (after Whalen et al., 1987).

The europium anomaly describes the measured value of Eu compared to the expected value when interpolating between the neighboring REE of Sm and Gd. Europium anomaly values $\left(\mathrm{Eu} / \mathrm{Eu}^{*}\right)$ were calculated using ICP-MS data normalized to C1 chondrite composition (Sun and McDonough, 1989) for Eu, Sm, Gd:

$$
E u / E u^{*}=E u / \sqrt{\operatorname{Sm} \times G d}
$$


A negative europium anomaly is generated by removal of Eu enriched plagioclase where $\mathrm{Eu}^{2+}$ has substituted for $\mathrm{Ca}^{2+}$. Larger negative europium anomalies are more common in the rhyolites from the southern area and the presumed younger units from the Owyhee region (Figure 17). The Littlefield Rhyolite, Dinner Creek Tuff, and presumed older units of the Owyhee retain smaller europium anomalies.

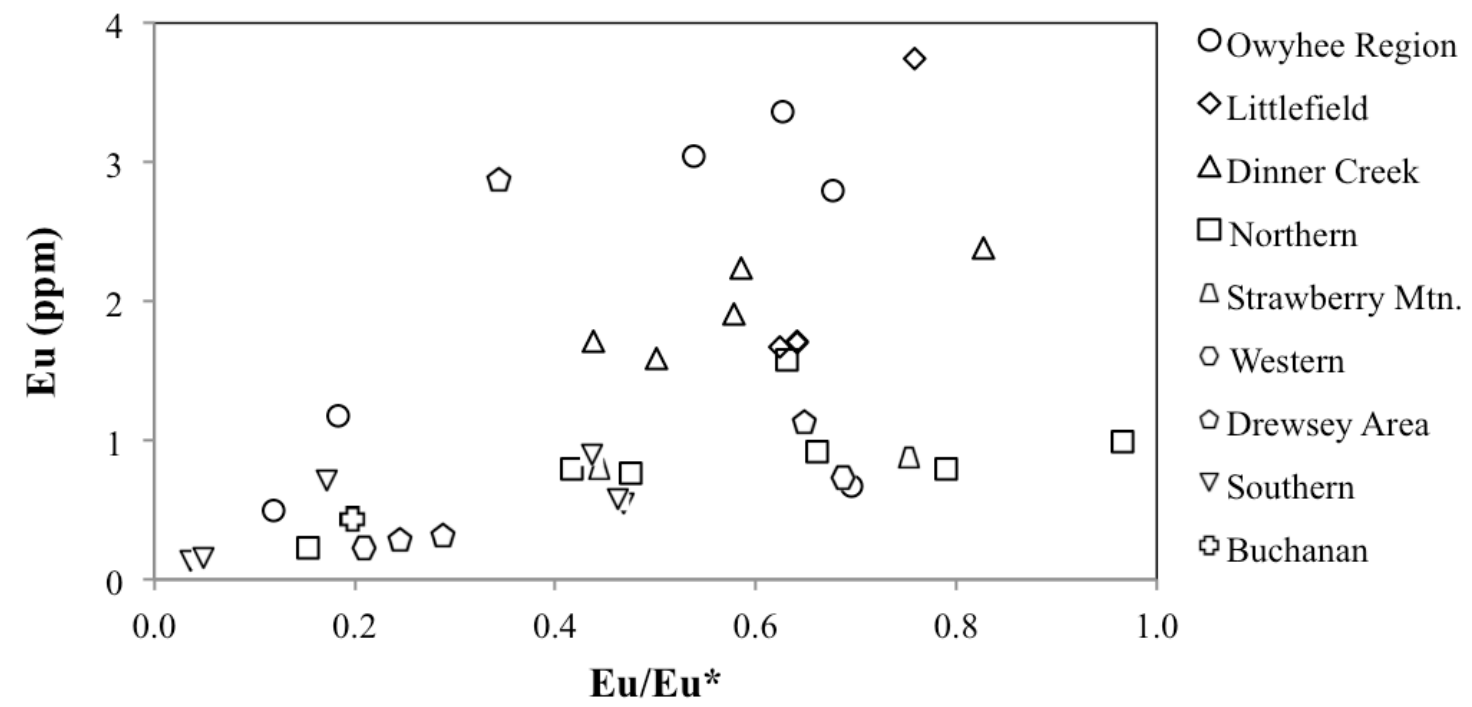

Figure 17. Diagram illustrating europium anomalies of rhyolites (calculated using Eq. 1).

The rhyolites of the study area show a variety of trends for incompatible trace elements in an average crust-normalized multi-element diagram using values of Rudnick and Gao (2003). Rhyolites were separated into six groups: northern transect, southern transect, central/western transect, Dinner Creek Tuff, Littlefield Rhyolite, and Owyhee region rhyolites. Northern, central/western transect, and southern transect have significant variations in trace element concentrations likely because they cover a wider region than the other three subsets or because the source rocks reflect different petrogenetic processes. The majority of rhyolites in the northern transect are enriched in $\mathrm{Ba}$ while the majority of rhyolites in the southern transect have Ba anomalies (Figure 18 and Figure 
19). Trace elements of the Littlefield Rhyolite clearly separate two distinct magma types;

EJ-12-10 has significant variations in numerous elements, including $\mathrm{Ba}, \mathrm{Nb}, \mathrm{P}$, and $\mathrm{Ti}$, relative to EJ-12-16, EJ-12-17, and MS-LFR1 (Figure 22). Rhyolite of Bully Creek has previously been recognized as retaining similar chemical characteristics as rhyolite of Cottonwood Mountain (Evans and Binger, 1999), but the lower unit of the Littlefield Rhyolite is chemically similar as well. Kittleman et al. (1967) mapped rhyolite of Bully Creek as part of their Littlefield Rhyolite but they described the Littlefield as stratigraphically above the Hunter Creek Basalt. Ferns et al. (1993) mapped the rhyolite of Cottonwood Mountain as part of the petrographically similar Littlefield Rhyolite.

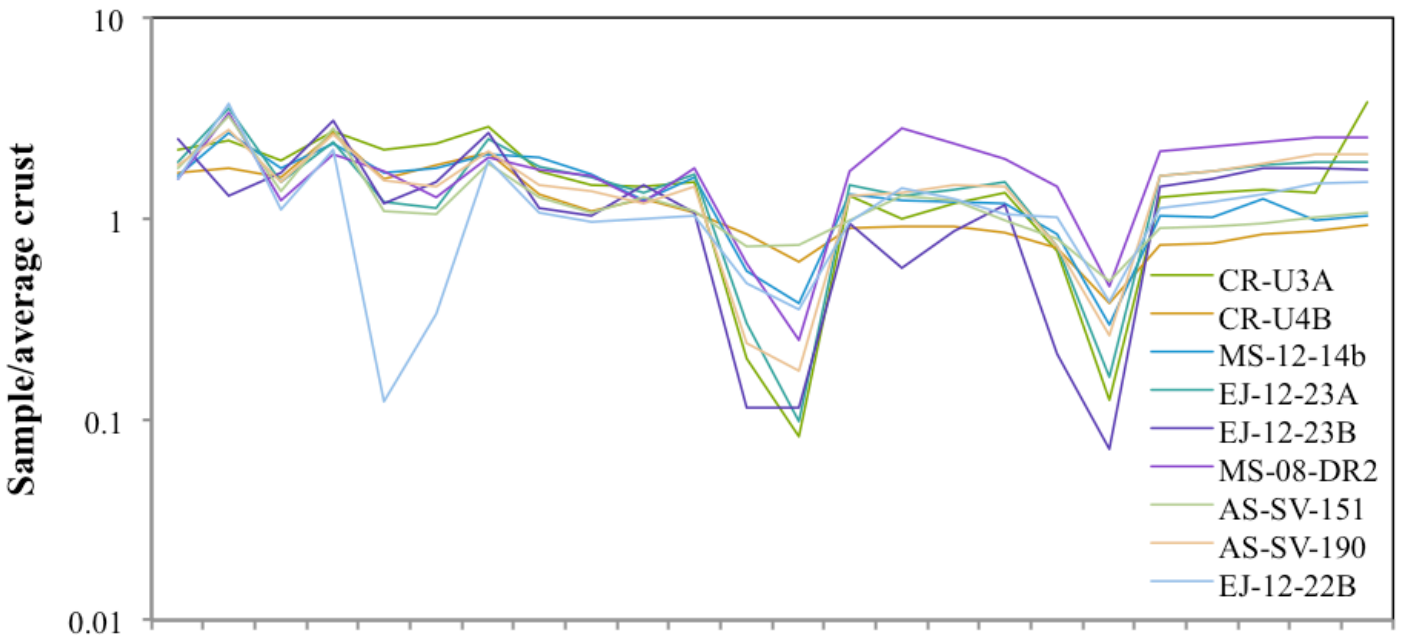

$\mathrm{Rb}$ Ba Th $\mathrm{U}$ Nb Ta K La Ce Pb Pr Sr P Nd Zr Hf Sm Eu Ti Tb Dy Y Yb Lu

Figure 18. Average crust-normalized multi-element diagram of rhyolites from the northern transect. EJ-12-22B (dacite of Ironside Mountain) has the greatest Nb anomaly. 


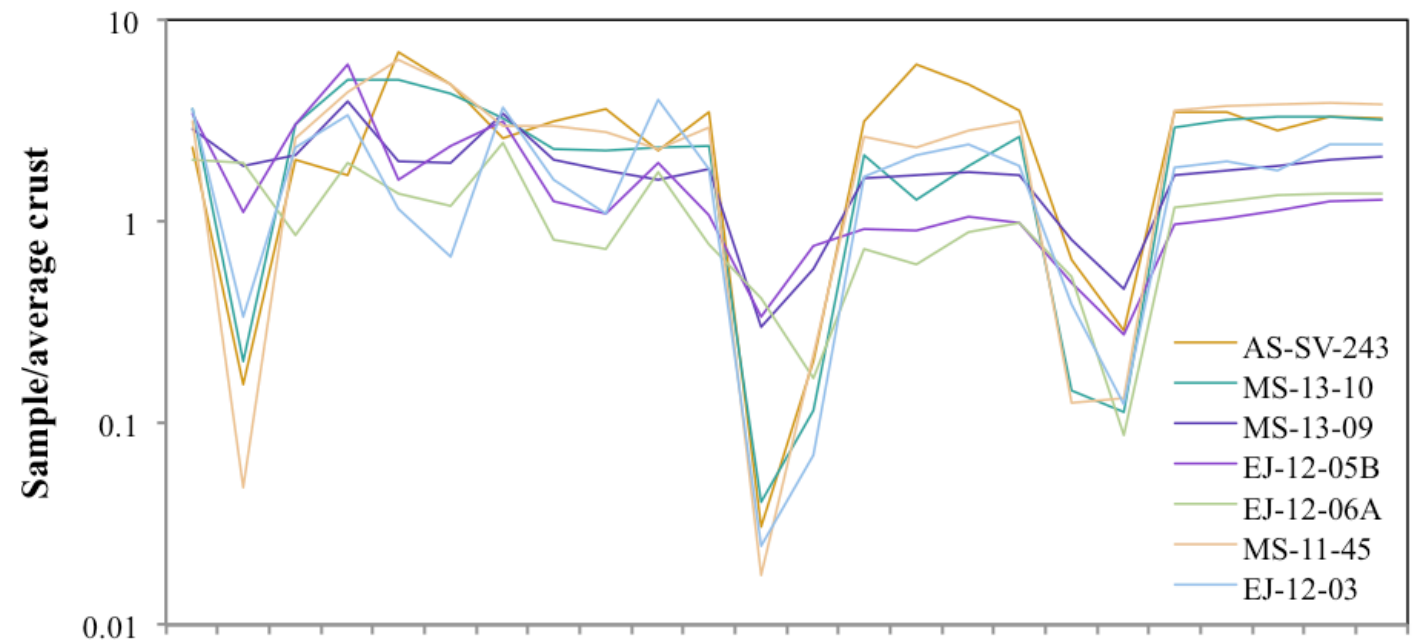

$\mathrm{Rb} \mathrm{Ba}$ Th $\mathrm{U}$ Nb Ta K La Ce Pb Pr Sr P Nd Zr Hf Sm Eu Ti Tb Dy Y Yb Lu

Figure 19. Average crust-normalized multi-element diagram of rhyolites from the southern transect. There is greater variation in the trace element concentrations in the southern transect relative to the northern transect (Figure 18).

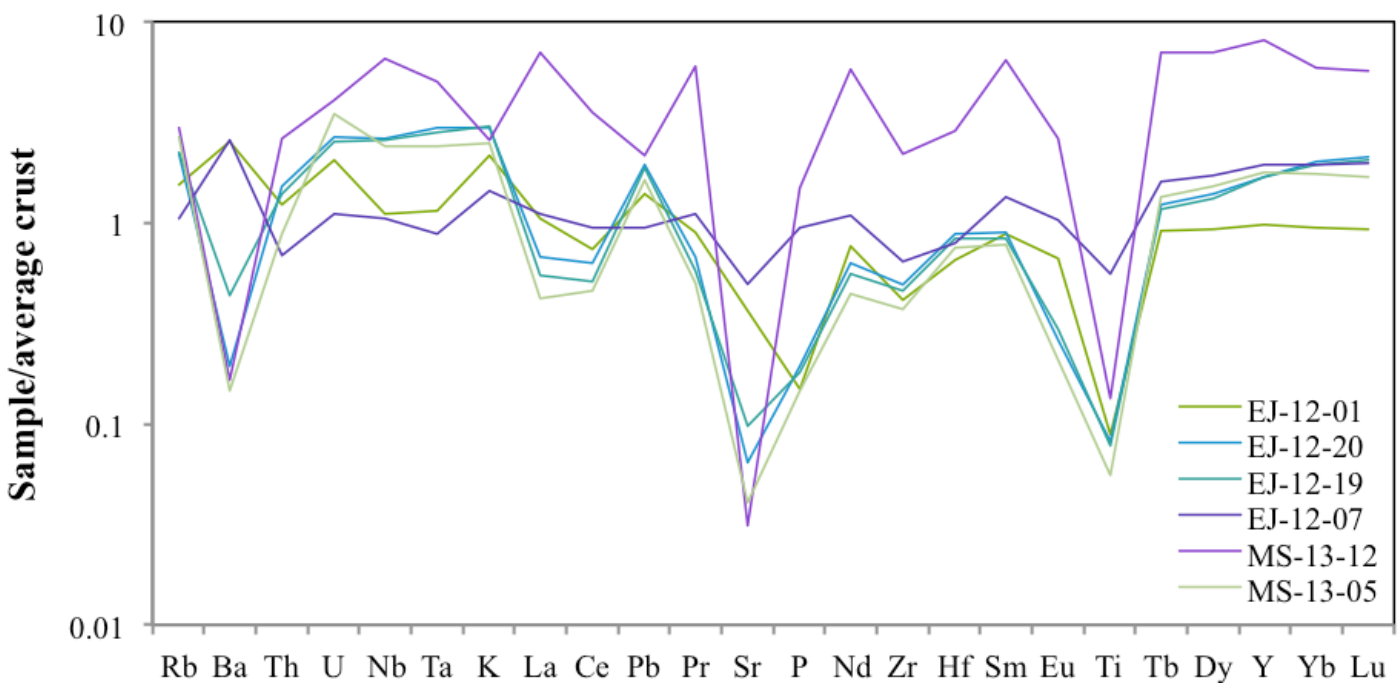

Figure 20. Average crust-normalized multi-element diagram of rhyolites from the western and central transect. MS-13-12 (Black Butte Rhyolite) creates the greatest variation in trace element concentrations among the samples from these transects. 


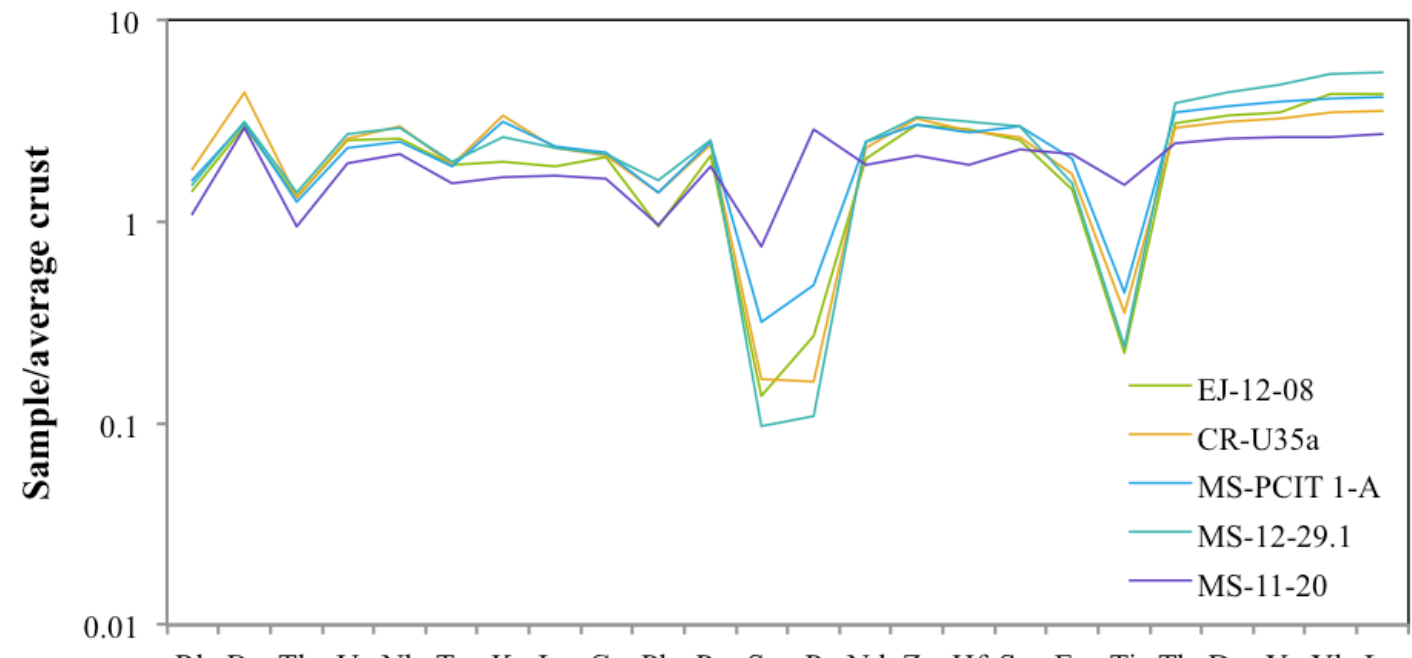

$\mathrm{Rb} \mathrm{Ba}$ Th $\mathrm{U}$ Nb Ta K La Ce Pb Pr Sr P Nd Zr Hf Sm Eu Ti Tb Dy Y Yb Lu

Figure 21. Average crust-normalized multi-element diagram of Dinner Creek samples. MS-11-20, which is classified as a dacite, has the greatest variation in trace element concentrations among the Dinner Creek samples.

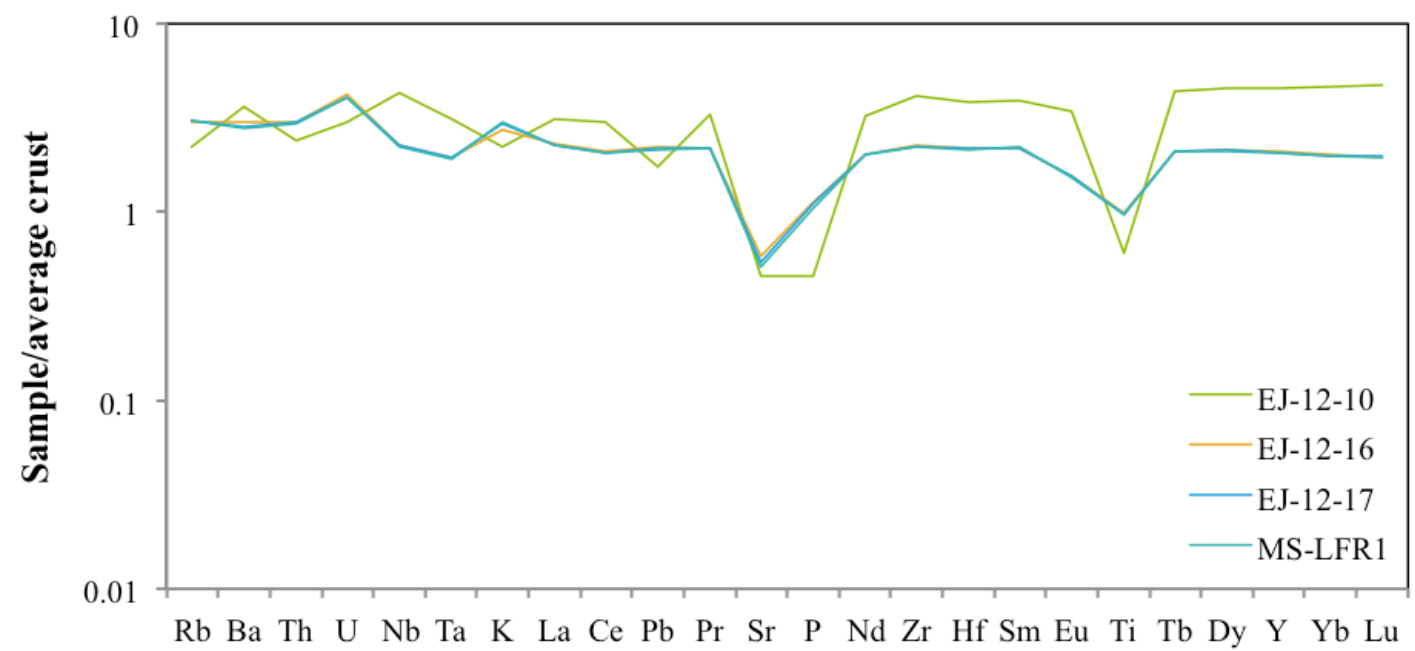

Figure 22. Average crust-normalized multi-element diagram of the Cottonwood Mountain, Bully Creek, and Littlefield Rhyolite. EJ-12-10 (upper Littlefield Rhyolite) has significant variation relative to the other rhyolites. 


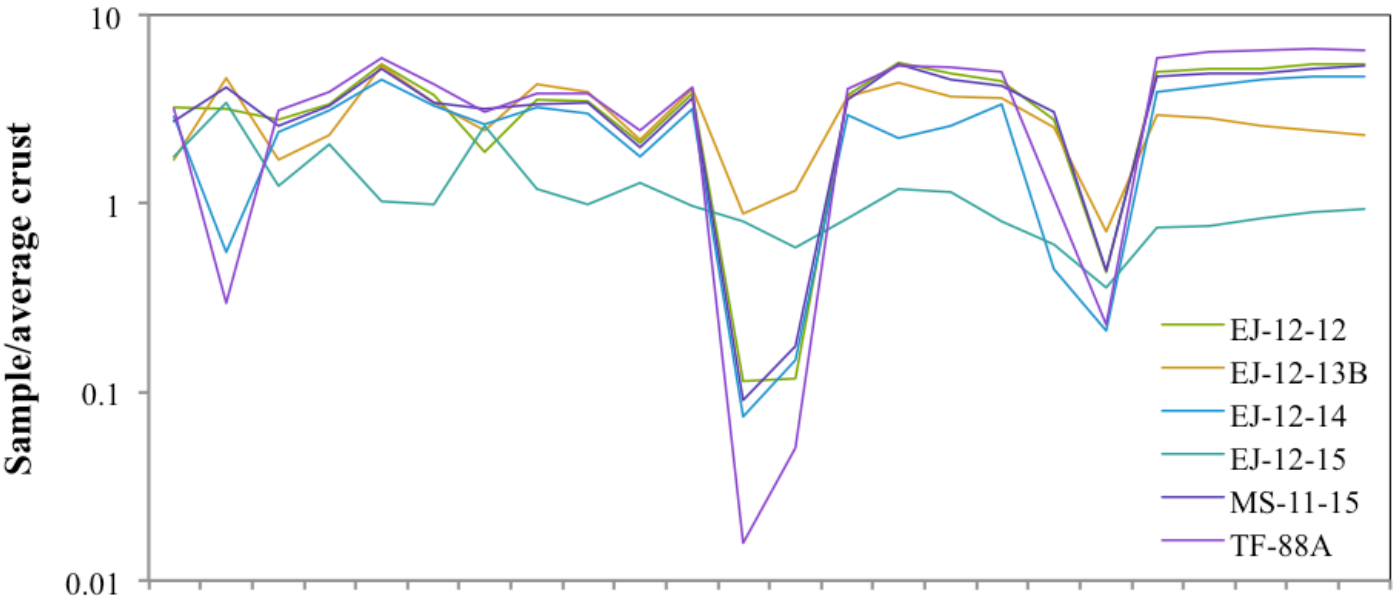

$\mathrm{Rb} \mathrm{Ba}$ Th $\mathrm{U}$ Nb Ta K La Ce Pb Pr Sr P Nd Zr Hf Sm Eu Ti Tb Dy Y Yb Lu

Figure 23. Average crust-normalized multi-element diagram of rhyolites from the Owyhee region. TF-88A (Three Fingers Intra-caldera Rhyolite) has the greatest Ba, Sr, and $P$ anomaly.

\section{Geochronology}

\section{Ar-Ar ages of select rhyolites from this study are displayed in}

Table 3. New ages of some rhyolites indicate the initiation of rhyolitic volcanism in the study region was essentially coeval with rhyolitic volcanism in the McDermitt area. Particularly old ages were obtained for EJ-12-10 and EJ-12-17 using the MAP instrument. These samples were reanalyzed using the Argus instrument and the age spectrums produced progressively younger ages (EJ-12-10) and older ages (EJ-12-17) at higher temperatures (Figure 32). This pattern of age varying with incremental heating steps is a result of ${ }^{39} \mathrm{Ar}$ recoil.

The dates obtained by Marcy et al. (2013) for Spring Creek Tuff (SCT) and intracaldera Three Fingers rhyolites (TFI) of LOVF show little time elapsed between the eruptions of the outflow tuff and intra-caldera rhyolite of the Owyhee region. 
Table 3. Ar-Ar age data for select rhyolites. MS-11-15 and TF-88A ages are from Marcy et al. (2013). AS-SV-151 and AS-SV-190 ages are from Steiner per. comm., while all other data were obtained in this study. Ages were calculated with FCT age of 28.201 Ma (Kuiper et al., 2008).

\begin{tabular}{lllccc}
\hline \hline Sample ID & Unit ID & \multicolumn{1}{c}{ Unit } & Age (Ma) & Material & Instrument \\
\hline EJ-12-03 & BDC & Buchanan Dome Complex & $16.13 \pm 0.11$ & sanidine & MAP \\
EJ-12-06A & SCR & Swamp Creek Rhyolite & $16.01 \pm 0.08$ & glass & MAP \\
EJ-12-07 & BER & Beulah Reservoir Trd & $16.29 \pm 0.21$ & groundmass & MAP \\
EJ-12-10 & LIR & Littlefield Rhyolite (upper) & $16.75 \pm 0.45$ & groundmass & MAP \\
EJ-12-12 & OMR & Old McIntyre Ridge Rhyolite & $15.94 \pm 0.16$ & sanidine & MAP \\
EJ-12-17 & RBC & Rhyolite of Bully Creek & $17.01 \pm 0.60$ & plagioclase & MAP \\
EJ-12-23A & DMR & Dooley Mountain Rhyolite & $15.59 \pm 0.04$ & plagioclase & ARGUS \\
MS-11-20 & DIT & Dinner Creek Tuff & $14.84 \pm 0.11$ & anorthoclase & MAP \\
AS-SV-151 & STR & Strawberry Mountain Rhyolite & $16.16 \pm 0.17$ & groundmass & MAP \\
AS-SV-190 & STR & Strawberry Mountain Rhyolite & $14.79 \pm 0.12$ & groundmass & MAP \\
MS-11-15 & SCT & Spring Creek Tuff & $15.74 \pm 0.09$ & sanidine & MAP \\
TF-88A & TFI & Three Fingers Intra-caldera Rhyolite & $15.74 \pm 0.08$ & sanidine & MAP \\
\hline
\end{tabular}

\section{Isotope Analysis}

Oxygen Isotopes

Table 4 contains oxygen isotope results acquired for this study. Complete oxygen isotopic results can be found in Appendix D. Values are highly variable between different silicic centers with $\delta^{18} \mathrm{O}$ ranging from 1.6 to $9.9 \%$. After applying a correction to determine the approximate bulk rock $\delta^{18} \mathrm{O}$ values (Eqns. D-1, Bindeman et al., 2004; D-2 Bindeman and Valley, 2002; D-3, Bindeman and Valley, 2003), the calculated magmatic values ranged from 2.1 to $10.5 \%$. Rhyolites from Dooley Mountain in the northern region have the highest $\delta^{18} \mathrm{O}$ values while the Littlefield/Cottonwood Mountain rhyolites have the lowest $\delta^{18} \mathrm{O}$ values. 
Table 4. Oxygen isotopic compositions of samples acquired from this study. The magmatic $\delta^{18} \mathrm{O}$ values are calculated using equations D-1, D-2, and D-3 (Appendix D), depending on the mineral analyzed.

\begin{tabular}{|c|c|c|c|c|}
\hline Sampl & & Material & $\delta^{18} \mathrm{O}(\%)$ & $\begin{array}{c}\text { Calculated } \delta^{18} \mathrm{O} \\
\text { magma }(\%)\end{array}$ \\
\hline \multicolumn{5}{|c|}{ Owyhee locality } \\
\hline OMR & EJ-12-12 & sanidine & 4.001 & 4.291 \\
\hline JCR & EJ-12-13B & sanidine & 8.399 & 8.689 \\
\hline YMR & EJ-12-14 & plagioclase & 5.944 & 6.576 \\
\hline DAM & EJ-12-15 & plagioclase & 6.674 & 7.189 \\
\hline SCT & MS-11-15 & sanidine & 3.959 & 4.249 \\
\hline TFI & TF-88A & sanidine & 5.705 & 5.995 \\
\hline \multicolumn{5}{|c|}{ Littlefield/Cottonwood Mountain } \\
\hline LIR & EJ-12-10 & whole rock & 3.881 & 3.881 \\
\hline LIR & EJ-12-10 & plagioclase & 2.436 & 2.905 \\
\hline CMR & EJ-12-16 & plagioclase & 2.350 & 2.872 \\
\hline $\mathrm{RBC}$ & EJ-12-17 & plagioclase & 1.635 & 2.139 \\
\hline LIR & MS-LFR1 & plagioclase & 1.806 & 2.308 \\
\hline \multicolumn{5}{|c|}{ Dinner Creek } \\
\hline DIT & EJ-12-08 & plagioclase & 6.849 & 7.503 \\
\hline DIT & CR-U35a & plagioclase & 6.430 & 6.981 \\
\hline DIT & MS-PCIT 1-A & sanidine & 7.489 & 7.779 \\
\hline DIT & MS-12-29.1 & plagioclase & 6.990 & 7.600 \\
\hline DIT & MS-11-20 & plagioclase & 6.339 & 6.724 \\
\hline \multicolumn{5}{|c|}{ Northern locality } \\
\hline UNI & CR-U3A & plagioclase & 7.226 & 7.830 \\
\hline UNI & CR-U4B & quartz & 7.230 & 6.780 \\
\hline UNI & MS-12-14b & plagioclase & 7.754 & 8.353 \\
\hline DMR & EJ-12-23A & plagioclase & 9.529 & 10.150 \\
\hline DMR & EJ-12-23B & - & - & - \\
\hline DMR & MS-08-DR2 & plagioclase & 9.905 & 10.450 \\
\hline IRM & EJ-12-22B & whole rock & 8.078 & 8.078 \\
\hline IRM & EJ-12-22B & plagioclase & 5.836 & 6.132 \\
\hline \multicolumn{5}{|c|}{ Strawberry Mountain } \\
\hline STR & AS-SV-151 & plagioclase & 7.336 & 7.862 \\
\hline STR & AS-SV-190 & glass & 6.702 & 6.702 \\
\hline \multicolumn{5}{|c|}{ Drewsey locality } \\
\hline TND & EJ-12-20 & - & - & - \\
\hline TSD & EJ-12-19 & - & - & - \\
\hline BER & EJ-12-07 & - & - & - \\
\hline BLB & MS-13-12 & plagioclase & 6.339 & 6.968 \\
\hline \multicolumn{5}{|c|}{ Southern locality } \\
\hline CBR & EJ-12-05B & quartz & 8.431 & 7.981 \\
\hline SCR & EJ-12-06A & glass & 6.685 & 6.685 \\
\hline STK & MS-11-45 & sanidine & 6.487 & 6.777 \\
\hline MCB & MS-13-09 & sanidine & 6.010 & 6.300 \\
\hline VCR & MS-13-10 & plagioclase & 6.603 & 7.228 \\
\hline
\end{tabular}




\begin{tabular}{lllrr} 
DCT & AS-SV-243 & sanidine & 5.097 & 5.387 \\
Western locality & & & \\
DNB EJ-12-01 & - & - & - \\
IDL $\quad$ MS-13-05 & - & - & - \\
Buchanan & & & \\
BDC $\quad$ EJ-12-03 & sanidine & 5.303 & 5.593 \\
BDC $\quad$ AL-13-015b & glass & 6.396 & 6.396 \\
\hline
\end{tabular}

\section{Radiogenic Isotopes}

$\mathrm{Sr}$ and $\mathrm{Pb}$ isotopic compositions are reported in Table 5 and Table 6, respectively. Complete isotopic results can be found in Appendix C. Sr isotopic compositions are variable between the different silicic centers. For the majority of rhyolites with feldspar and groundmass data, feldspar phenocrysts are in $\mathrm{Sr}$ isotopic equilibrium with groundmass. This is expected given the low proportion of feldspar phenocrysts and petrographic evidence (e.g., euhedral, no significant resorption boundaries) that feldspars crystallized in the host magma.

Table 5. Sr isotope data for feldspar (fsp) and groundmass (GM). ${ }^{87} \mathrm{Sr} /{ }^{86} \mathrm{Sr}$ (initial) calculated using equation C-1 (Appendix C). Concentrations of Sr and $\mathrm{Rb}$ are available in Table 9 (Appendix C).

\begin{tabular}{|c|c|c|c|c|c|c|c|}
\hline \multirow{2}{*}{\multicolumn{2}{|c|}{ Sample }} & \multicolumn{2}{|c|}{ 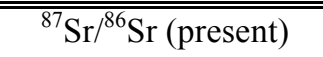 } & \multicolumn{2}{|c|}{$2 \sigma$ error } & \multicolumn{2}{|c|}{ 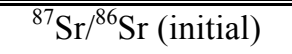 } \\
\hline & & fsp & GM & fsp & GM & fsp & GM \\
\hline \multicolumn{8}{|c|}{ Owyhee locality } \\
\hline OMR & EJ-12-12 & 0.704990 & 0.707632 & 0.000022 & 0.000015 & 0.704644 & 0.704865 \\
\hline JCR & EJ-12-13B & 0.705682 & - & 0.000010 & - & 0.705666 & - \\
\hline YMR & EJ-12-14 & 0.704575 & 0.708181 & 0.000015 & 0.000015 & 0.704128 & 0.704603 \\
\hline DAM & EJ-12-15 & - & 0.704327 & - & 0.000011 & - & 0.704144 \\
\hline $\mathrm{SCT}$ & MS-11-15 & 0.704970 & 0.708270 & 0.000011 & 0.000011 & 0.704606 & 0.705361 \\
\hline TFI & TF-88A & 0.707846 & 0.731446 & 0.000015 & 0.000011 & 0.704673 & 0.701976 \\
\hline \multicolumn{8}{|c|}{ Littlefield/Cottonwood Mountain } \\
\hline LIR & EJ-12-10 & - & 0.705637 & - & 0.000013 & - & 0.705142 \\
\hline CMR & EJ-12-16 & - & 0.707205 & - & 0.000010 & - & 0.706712 \\
\hline $\mathrm{RBC}$ & EJ-12-17 & 0.706668 & - & 0.000022 & - & 0.706595 & - \\
\hline LIR & MS-LFR1 & 0.706647 & 0.707301 & 0.000021 & 0.000015 & 0.706646 & 0.706677 \\
\hline \multicolumn{8}{|c|}{ Dinner Creek } \\
\hline DIT & EJ-12-08 & & 0.705559 & & 0.000014 & - & 0.704551 \\
\hline DIT & CR-U35a & 0.704216 & 0.704921 & 0.000008 & 0.000013 & 0.704207 & 0.703890 \\
\hline DIT & MS-PCIT 1-A & 0.704414 & 0.705053 & 0.000010 & 0.000032 & 0.704315 & 0.704261 \\
\hline DIT & MS-12-29.1 & 0.704164 & 0.706008 & 0.000049 & 0.000015 & 0.704159 & 0.704463 \\
\hline
\end{tabular}




\begin{tabular}{lccccccc} 
DIT & MS-11-20 & 0.704170 & - & 0.000014 & - & 0.704154 & - \\
Northern locality & & & & & & \\
UNI & CR-U3A & 0.703836 & 0.704921 & 0.000011 & 0.000013 & 0.703699 & 0.703828 \\
UNI & CR-U4B & 0.703820 & 0.704271 & 0.000013 & 0.000014 & 0.703819 & 0.704067 \\
UNI & MS-12-14b & 0.703730 & - & 0.000008 & - & 0.703730 & - \\
DMR & EJ-12-23A & 0.704444 & 0.705171 & 0.000010 & 0.000015 & 0.704443 & 0.704575 \\
DMR & EJ-12-23B & - & 0.706697 & - & 0.000013 & - & 0.704643 \\
DMR & MS-08-DR2 & 0.704814 & 0.705088 & 0.000014 & 0.000008 & 0.704783 & 0.704841 \\
IRM & EJ-12-22B & - & 0.703772 & - & 0.000014 & - & 0.703727 \\
Strawberry Mountain & & & & & & \\
STR & AS-SV-151 & - & 0.704294 & - & 0.000013 & - & 0.704054 \\
STR & AS-SV-190 & - & 0.704994 & - & 0.000011 & - & 0.704303 \\
Drewsey locality & & & & & & \\
TND & EJ-12-20 & - & 0.705807 & - & 0.000014 & - & 0.703303 \\
TSD & EJ-12-19 & - & 0.705554 & - & 0.000013 & - & 0.703898 \\
BER & EJ-12-07 & - & 0.704145 & - & 0.000015 & - & 0.703937 \\
BLB & MS-13-12 & 0.710698 & 0.714644 & 0.000046 & 0.000011 & 0.703650 & 0.700718 \\
Southern locality & & & & & & \\
CBR & EJ-12-05B & 0.704874 & & 0.000014 & & 0.704800 & - \\
SCR & EJ-12-06A & - & 0.704548 & - & 0.000011 & - & 0.704078 \\
STK & MS-11-45 & 0.706244 & 0.730827 & 0.000013 & 0.000014 & 0.704897 & 0.704631 \\
MCB & MS-13-09 & 0.704780 & 0.706235 & 0.000010 & 0.000031 & 0.704408 & 0.704128 \\
VCR & MS-13-10 & 0.706179 & 0.779998 & 0.000024 & 0.000011 & 0.704912 & 0.683238 \\
DCT & AS-SV-243 & 0.705758 & & 0.000020 & & 0.704958 & - \\
Western locality & & & & & & \\
DNB & EJ-12-01 & - & 0.704237 & - & 0.000011 & - & 0.703878 \\
IDL & MS-13-05 & - & 0.708009 & - & 0.000011 & - & 0.703430 \\
Buchanan & & & & & & \\
BDC & EJ-12-03 & 0.709250 & 0.722852 & 0.000020 & 0.000021 & 0.704851 & 0.698936 \\
BDC & AL-13-015b & - & 0.704802 & - & 0.000011 & - & 0.704060 \\
\hline
\end{tabular}

Table 6. $\mathrm{Pb}$ isotopic compositions of groundmass and whole rock.

\begin{tabular}{|c|c|c|c|c|c|c|c|}
\hline \multicolumn{2}{|c|}{ Sample } & 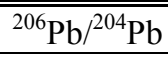 & $2 \sigma$ error & ${ }^{{ }^{207} \mathrm{~Pb} /{ }^{204} \mathrm{~Pb}}$ & $2 \sigma$ error & ${ }^{{ }^{208} \mathrm{~Pb} /} /{ }^{204} \mathrm{~Pb}$ & $2 \sigma$ error \\
\hline \multicolumn{8}{|c|}{ Owyhee locality } \\
\hline OMR & EJ-12-12 & 18.888 & 0.001 & 15.610 & 0.001 & 38.757 & 0.002 \\
\hline JCR & EJ-12-13B & 18.911 & 0.001 & 15.608 & 0.001 & 38.673 & 0.002 \\
\hline YMR & EJ-12-14 & - & - & - & - & - & - \\
\hline DAM & EJ-12-15 & - & - & - & - & - & - \\
\hline SCT & MS-11-15 & 18.885 & 0.001 & 15.607 & 0.001 & 38.749 & 0.002 \\
\hline TFI & TF-88A & 18.879 & 0.001 & 15.607 & 0.001 & 38.723 & 0.002 \\
\hline \multicolumn{8}{|c|}{ Littlefield/Cottonwood Mountain } \\
\hline LIR & EJ-12-10 & - & - & - & - & - & - \\
\hline CMR & EJ-12-16 & - & - & - & - & - & - \\
\hline $\mathrm{RBC}$ & EJ-12-17 & - & - & - & - & - & - \\
\hline LIR & MS-LFR1 & 18.820 & 0.001 & 15.610 & 0.001 & 38.800 & 0.002 \\
\hline \multicolumn{8}{|c|}{ Dinner Creek } \\
\hline DIT & EJ-12-08 & 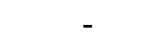 & - & - & - & 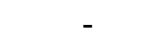 & \\
\hline
\end{tabular}




\begin{tabular}{|c|c|c|c|c|c|c|c|}
\hline DIT & CR-U35a & - & - & - & - & - & - \\
\hline DIT & MS-PCIT 1-A & 18.913 & 0.001 & 16.000 & 0.001 & 38.493 & 0.002 \\
\hline DIT & MS-12-29.1 & - & - & - & - & - & - \\
\hline DIT & MS-11-20 & - & - & - & - & - & - \\
\hline \multicolumn{8}{|c|}{ Northern locality } \\
\hline UNI & CR-U3A & 18.866 & 0.001 & 15.588 & 0.001 & 38.495 & 0.002 \\
\hline UNI & CR-U4B & - & - & - & - & - & - \\
\hline UNI & MS-12-14b & - & - & - & - & - & - \\
\hline DMR & EJ-12-23A & 18.935 & 0.001 & 15.605 & 0.001 & 38.550 & 0.002 \\
\hline DMR & EJ-12-23B & 18.934 & 0.001 & 15.605 & 0.001 & 38.532 & 0.002 \\
\hline DMR & MS-08-DR2 & - & - & - & - & - & - \\
\hline IRM & EJ-12-22B & - & - & - & - & - & - \\
\hline \multicolumn{8}{|c|}{ Strawberry Mountain } \\
\hline STR & AS-SV-151 & 18.868 & 0.001 & 15.596 & 0.001 & 38.484 & 0.003 \\
\hline STR & AS-SV-190 & 18.900 & 0.001 & 15.595 & 0.001 & 38.506 & 0.002 \\
\hline \multicolumn{8}{|c|}{ Drewsey locality } \\
\hline TND & EJ-12-20 & - & - & - & - & - & - \\
\hline TSD & EJ-12-19 & - & - & - & - & - & - \\
\hline BER & EJ-12-07 & - & - & - & - & - & - \\
\hline BLB & MS-13-12 & - & - & - & - & - & - \\
\hline \multicolumn{8}{|c|}{ Southern locality } \\
\hline CBR & EJ-12-05B & - & - & - & - & - & - \\
\hline SCR & EJ-12-06A & - & - & - & - & - & - \\
\hline STK & MS-11-45 & 18.799 & 0.001 & 15.607 & 0.001 & 38.748 & 0.003 \\
\hline MCB & MS-13-09 & - & - & - & - & - & - \\
\hline VCR & MS-13-10 & - & - & - & - & - & - \\
\hline DCT & AS-SV-243 & - & - & - & - & - & - \\
\hline \multicolumn{8}{|c|}{ Western locality } \\
\hline DNB & EJ-12-01 & - & - & - & - & - & - \\
\hline IDL & MS-13-05 & - & - & - & - & - & - \\
\hline \multicolumn{8}{|c|}{ Buchanan } \\
\hline $\mathrm{BDC}$ & EJ-12-03 & 18.991 & 0.001 & 15.603 & 0.001 & 38.575 & 0.002 \\
\hline $\mathrm{BDC}$ & AL-13-015b & - & - & - & - & - & - \\
\hline
\end{tabular}

Overall, the data indicate a significant range in $\mathrm{Pb}$ isotopic data, but data of individual regions tend to plot close to one another in comparison to the entire data field (Figures 24, 25, and 26). ${ }^{208} \mathrm{~Pb} /{ }^{204} \mathrm{~Pb}-{ }^{206} \mathrm{~Pb} /{ }^{204} \mathrm{~Pb}$ ratios of rhyolites define two trends that converge at high ${ }^{206} \mathrm{~Pb} /{ }^{204} \mathrm{~Pb}$. Towards lower ${ }^{206} \mathrm{~Pb} /{ }^{204} \mathrm{~Pb}$ values, one trend develops progressively higher ${ }^{208} \mathrm{~Pb} /{ }^{204} \mathrm{~Pb}$ values (i.e. originally high $\mathrm{Th} / \mathrm{U}$ values) while the other trend develops lower ${ }^{208} \mathrm{~Pb} /{ }^{204} \mathrm{~Pb}$ values (i.e. originally slightly lower $\mathrm{Th} / \mathrm{U}$ values) compared to ${ }^{208} \mathrm{~Pb} /{ }^{204} \mathrm{~Pb}$ values with higher ${ }^{206} \mathrm{~Pb} /{ }^{204} \mathrm{~Pb}$ values. 


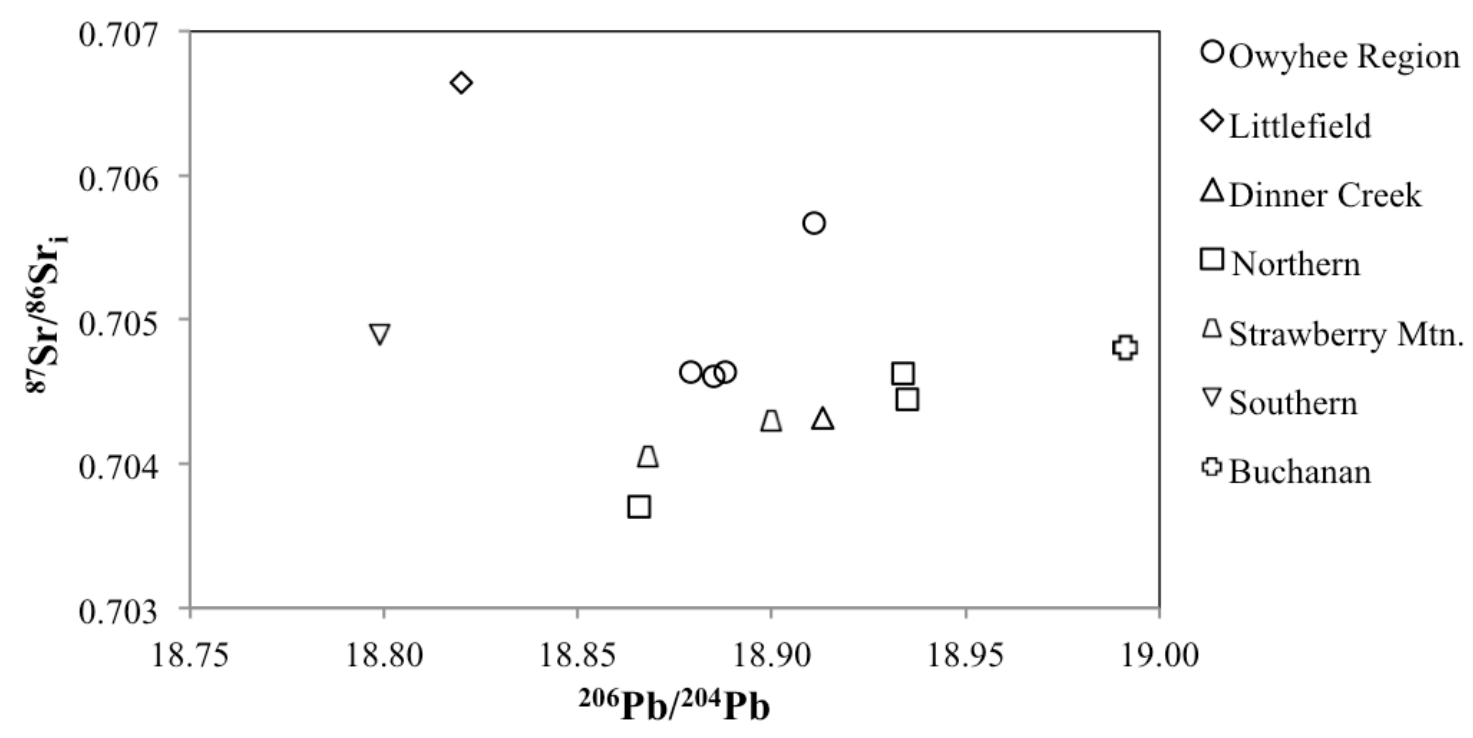

Figure 24. Variation diagram illustrating ${ }^{87} \mathrm{Sr} /{ }^{86} \mathrm{Sr}_{\mathrm{i}}$ versus ${ }^{206} \mathrm{~Pb} /{ }^{204} \mathrm{~Pb}$ signatures. ${ }^{87} \mathrm{Sr}^{86} \mathrm{Sr}_{\mathrm{i}}$ data are from feldspars; if there are no data for feldspar of a particular sample, the ${ }^{87} \mathrm{Sr}^{86} \mathrm{Sr}_{i}$ data are from groundmass.

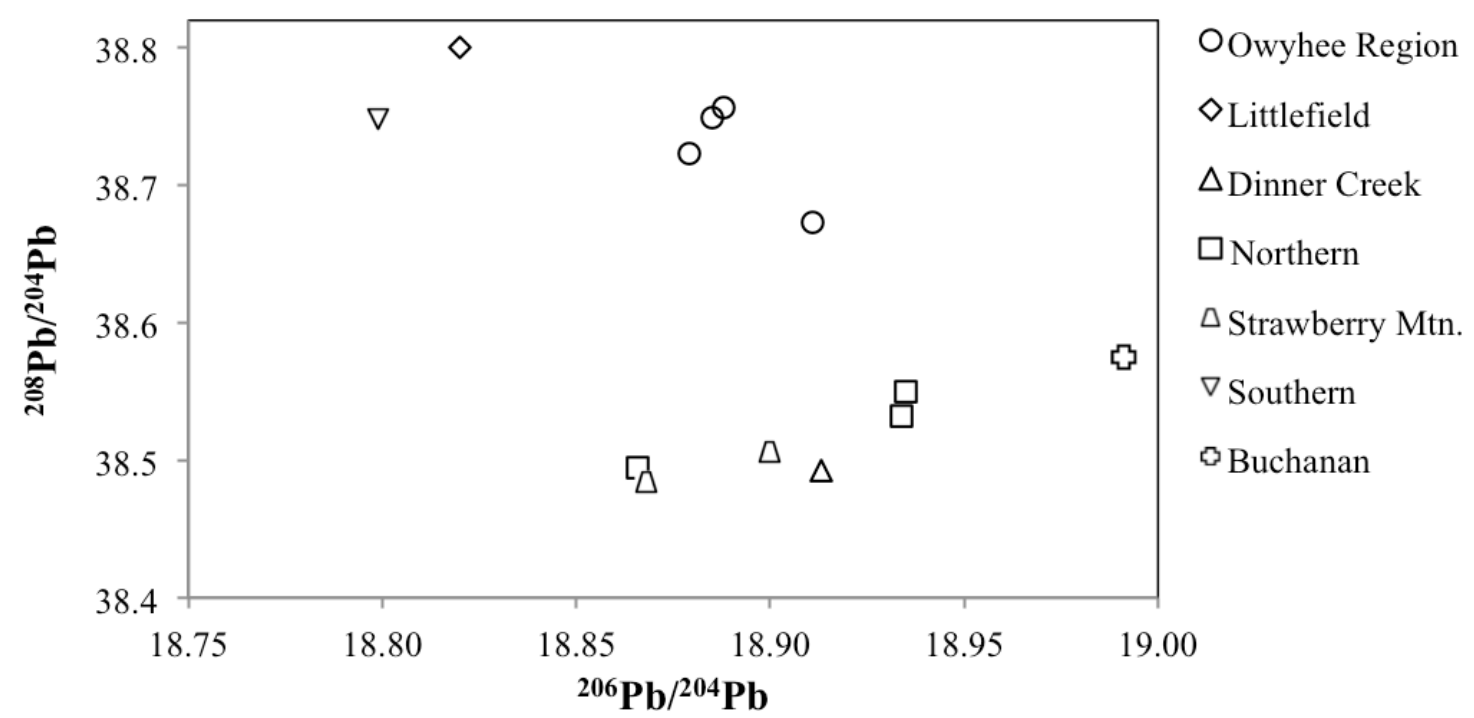

Figure $25 .{ }^{208} \mathrm{~Pb} /{ }^{204} \mathrm{~Pb}$ versus ${ }^{206} \mathrm{~Pb} /{ }^{204} \mathrm{~Pb}$ variation diagram illustrating rhyolite groundmass signatures. 


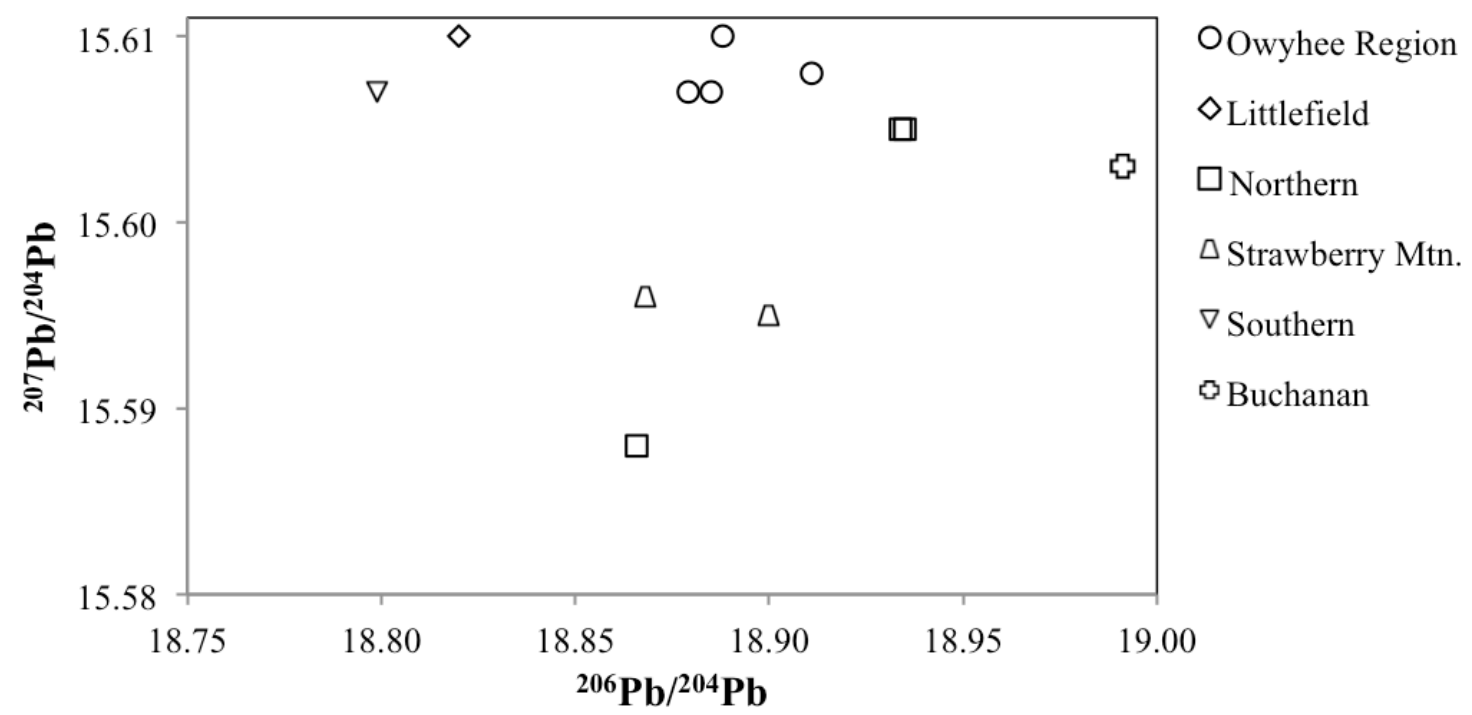

Figure $26 .{ }^{207} \mathrm{~Pb} /{ }^{204} \mathrm{~Pb}$ versus ${ }^{206} \mathrm{~Pb} /{ }^{204} \mathrm{~Pb}$ variation diagram illustrating rhyolite groundmass signatures. Dinner Creek sample MS-PCIT-1A is an outlier at ${ }^{207} \mathrm{~Pb} /{ }^{204} \mathrm{~Pb}=16.000$ and is not included in figure.

Overall, there is a significant range in oxygen isotope data with $\delta^{18} \mathrm{O}$ values for mineral separates and groundmass ranging from below $2 \%$ to above $9 \%$ (Figure 27). There is a crude trend of rhyolites having lower $\delta^{18} \mathrm{O}$ and more radiogenic ${ }^{87} \mathrm{Sr}^{86} \mathrm{Sr}_{\mathrm{i}}$ ratios. All rhyolites with low $\delta^{18} \mathrm{O}\left(\delta^{18} \mathrm{O}<5.5 \%\right.$ ) have ${ }^{87} \mathrm{Sr} /{ }^{86} \mathrm{Sr}_{\mathrm{i}}$ above 0.7045 , while rhyolites with $\delta^{18} \mathrm{O}>6 \%$ retain a wide range of ${ }^{87} \mathrm{Sr}^{86}{ }^{86} r_{\mathrm{i}}$ from 0.7035 to above 0.7050 . Rhyolites with the lowest $\delta^{18} \mathrm{O}\left(\delta^{18} \mathrm{O}<2 \%\right.$ ) come from rhyolites $\sim 80 \mathrm{~km}$ west of the cratonic margin reflecting remelting or assimilation of hydrothermally altered crust. 


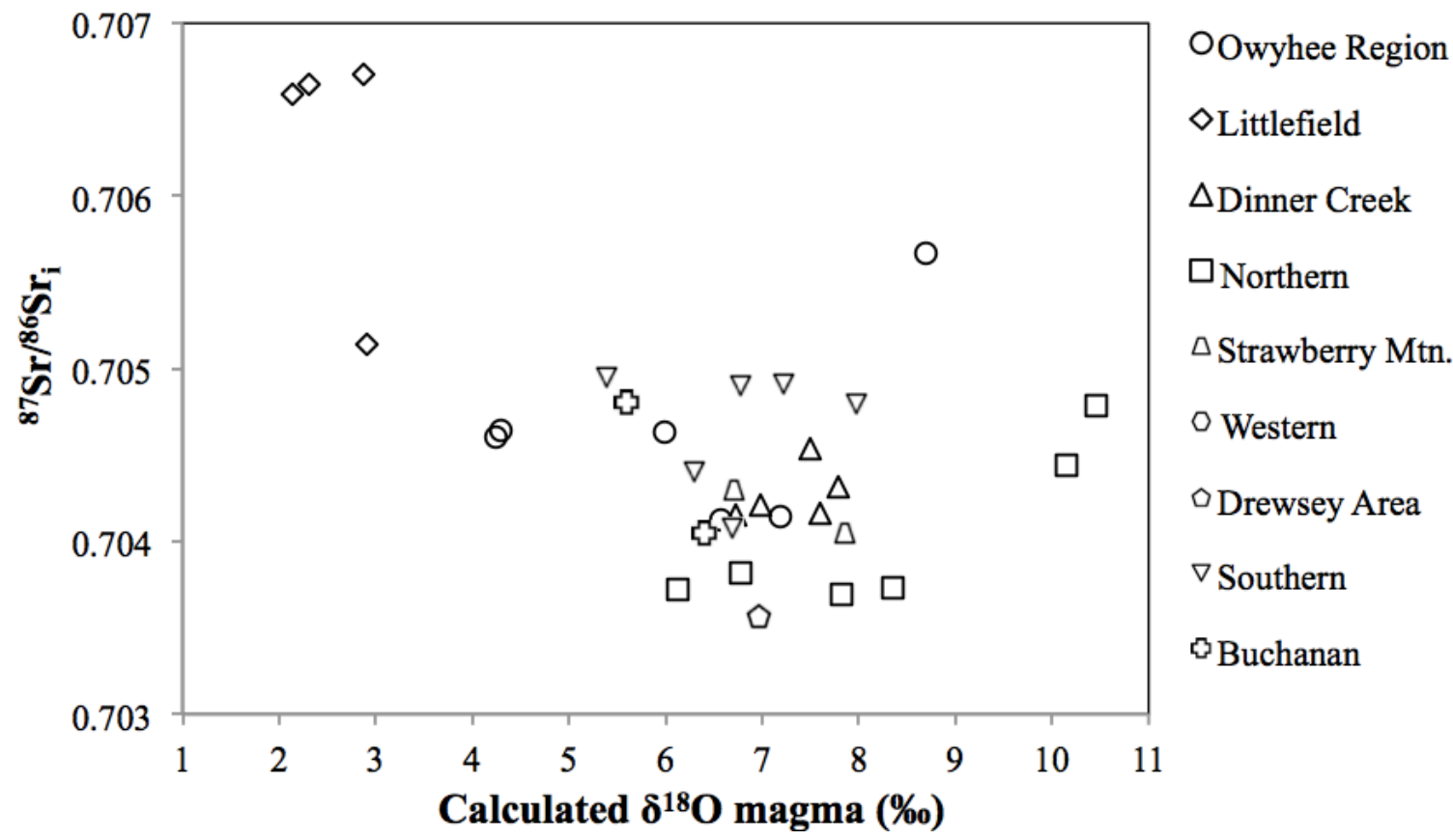

Figure $27 .{ }^{87} \mathrm{Sr} /{ }^{86} \mathrm{Sr}_{\mathrm{i}}$ versus calculated $\delta^{18} \mathrm{O}$ magma (\%o) variation diagram illustrating significant range in $\delta^{18} \mathrm{O} .{ }^{87} \mathrm{Sr} /{ }^{86} \mathrm{Sr}_{\mathrm{i}}$ data are from feldspars; if there are no data for feldspar of a particular sample, the ${ }^{87} \mathrm{Sr} /{ }^{86} \mathrm{Sr}_{\mathrm{i}}$ data are from groundmass.

Except for rare examples in the western part of the study area, dispersion of ${ }^{87} \mathrm{Sr} /{ }^{86} \mathrm{Sr}_{\mathrm{i}}$ ratios among both silicic and basaltic rocks occurs eastward of $118.6^{\circ} \mathrm{W}$ (cf. Ford et al., 2013). For example, rhyolites in the Owyhee region between $117.10^{\circ} \mathrm{W}$ and $117.25^{\circ} \mathrm{W}$ have ${ }^{87} \mathrm{Sr} /{ }^{86} \mathrm{Sr}_{\mathrm{i}}$ ratios that range widely from 0.7041 to 0.7057 . Highway 20 , which runs predominately in an E-W direction in the study region, is the approximate boundary separating higher ${ }^{87} \mathrm{Sr} /{ }^{86} \mathrm{Sr}_{\mathrm{i}}$ rhyolites to the south from lower ${ }^{87} \mathrm{Sr} /{ }^{86} \mathrm{Sr}_{\mathrm{i}}$ rhyolites to the north. Further east of $118^{\circ} \mathrm{W}$, this transition trends more NE-SW and incorporates the higher ${ }^{87} \mathrm{Sr} /{ }^{86} \mathrm{Sr}_{i}$ units of Littlefield Rhyolite and rhyolite of Cottonwood Mountain (Figure 29). In general, higher ${ }^{87} \mathrm{Sr} /{ }^{86} \mathrm{Sr}_{\mathrm{i}}$ ratios $(>0.7040)$ correspond to samples that are A-type rhyolites (Figure 28). 


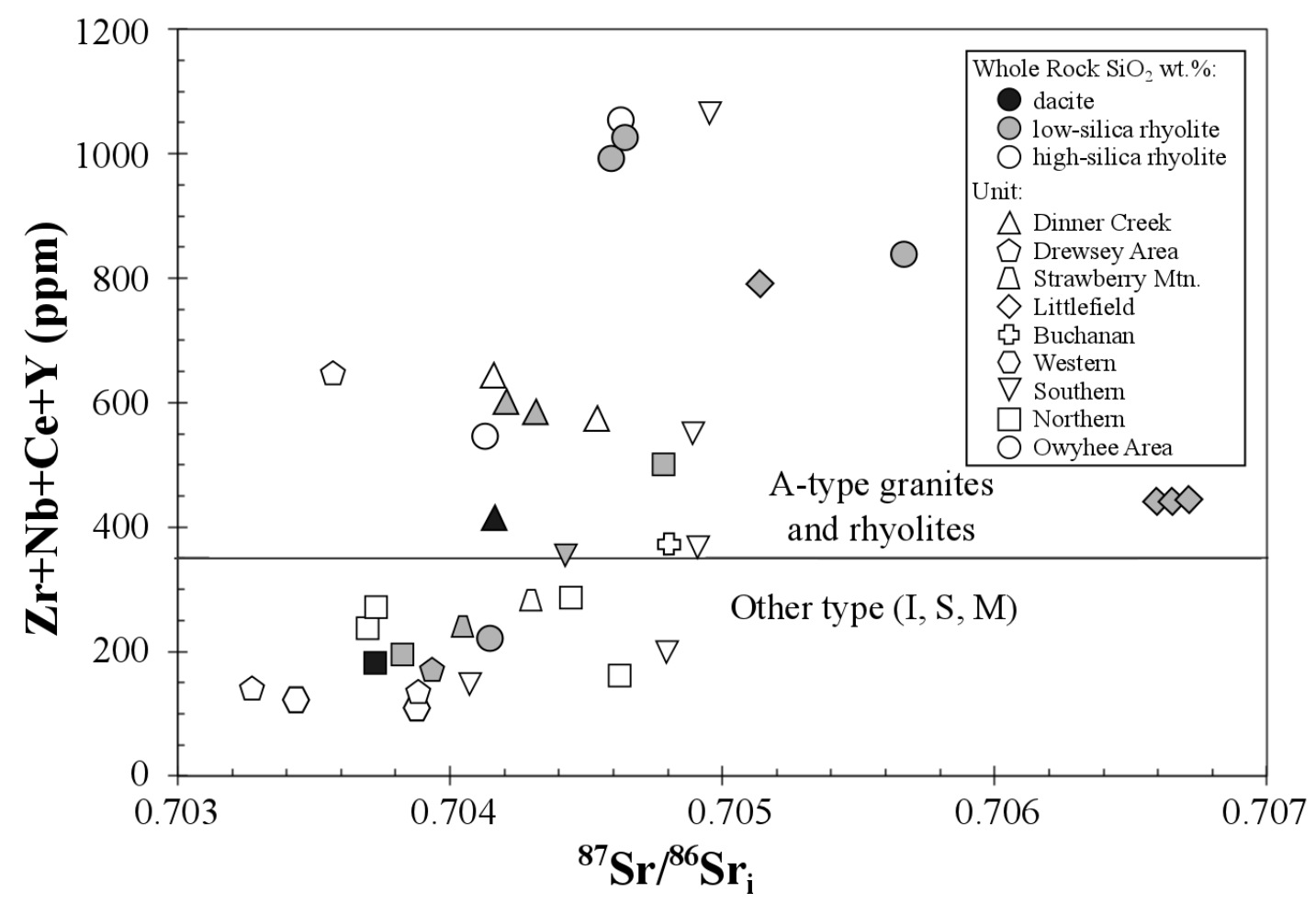

Figure 28. Diagram illustrating $\mathrm{Zr}+\mathrm{Nb}+\mathrm{Ce}+\mathrm{Y}(\mathrm{ppm})$ of whole rocks and corresponding ${ }^{87} \mathrm{Sr}^{86} \mathrm{Sr}_{\mathrm{i}}$. ${ }^{87} \mathrm{Sr}^{86} \mathrm{Sr}_{\mathrm{i}}$ data are from feldspars; if there are no data for feldspar of a particular sample, the ${ }^{87} \mathrm{Sr} /{ }^{86} \mathrm{Sr}_{\mathrm{i}}$ data are from groundmass. The majority of samples are classified as A-type rhyolites, after Whalen et al. (1987), and A-type rhyolites are in general more radiogenic than others. Samples are coded for whole rock $\mathrm{SiO}_{2}($ wt.\%) content; black is dacite $(<70 \%)$, grey is low-silica rhyolite $(<75 \%)$, unfilled is high-silica rhyolite $(>75 \%)$. 


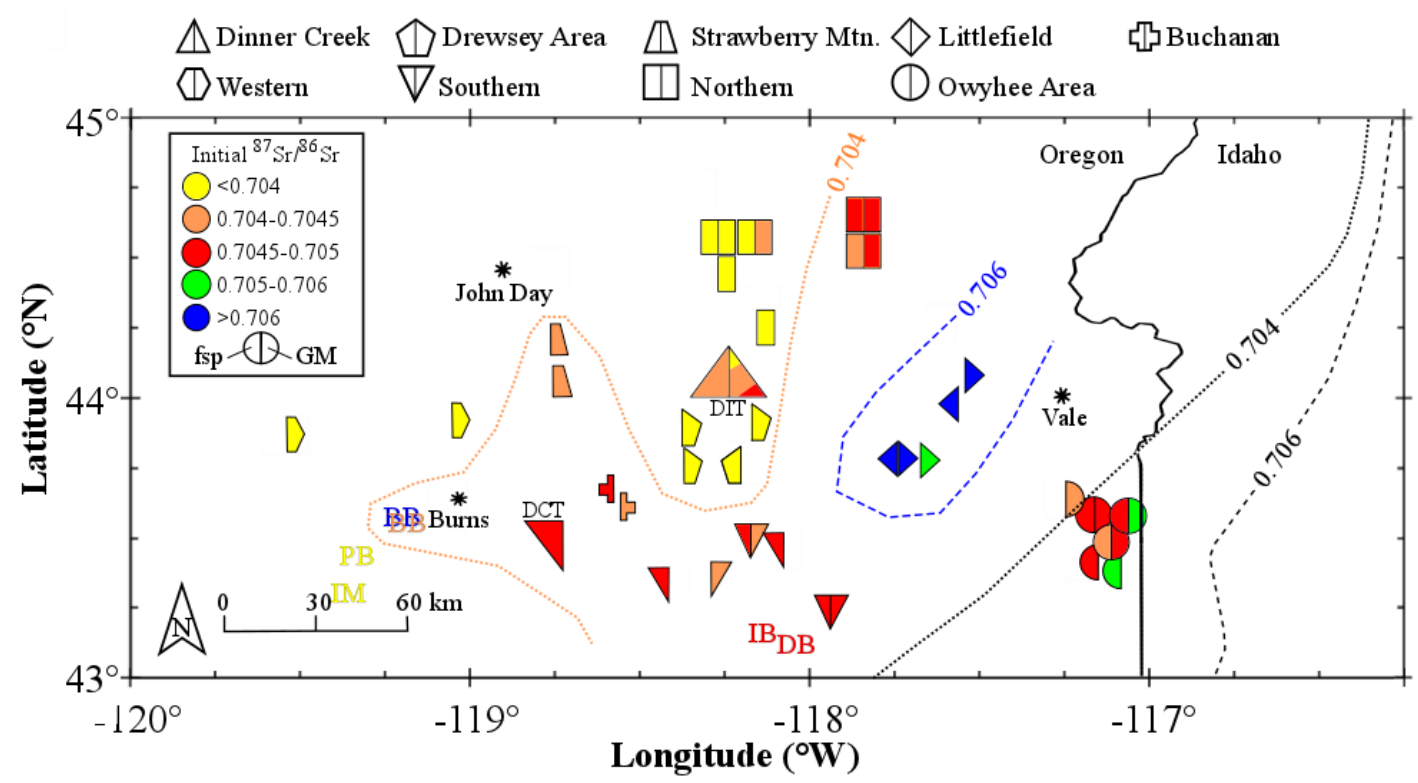

Figure 29. Map illustrating sample locations with age corrected ${ }^{87} \mathrm{Sr}^{86} \mathrm{Sr}_{\mathrm{i}}$ ratios from feldspar or groundmass. Shading of icon is defined as: left part of icon reflects ${ }^{87} \mathrm{Sr}^{86} \mathrm{Sr}_{\mathrm{i}}$ ratio of feldspar while the right part of icon reflects ${ }^{87} \mathrm{Sr} /{ }^{86} \mathrm{Sr}_{i}$ ratio of groundmass. The traditional ${ }^{87} \mathrm{Sr}^{86} \mathrm{Sr}_{\mathrm{i}}=0.7040$ and 0.7060 isochrones are represented by dashed black lines are after Pierce and Morgan (2009). Our proposed 0.7040 (orange) and 0.7060 (blue) ${ }^{87} \mathrm{Sr}^{86} \mathrm{Sr}_{i}$ isochrones are dashed. Literature data in the region are included as abbreviations: BB- Burns Butte, IM- Iron Mt, PB- Palomino Butte, DB- Duck Creek Butte, IB- Indian Creek Butte (Streck and Grunder, 2008; Ford, 2011). Devine Canyon Tuff and Dinner Creek Tuff symbols correspond to inferred source locations for these tuffs, although samples were collected from different locations (Table 2). 


\section{DISCUSSION}

This study presents new $\mathrm{Sr}, \mathrm{O}, \mathrm{Pb}$ isotope data and ${ }^{40} \mathrm{Ar} /{ }^{39} \mathrm{Ar}$ ages of mostly rhyolitic, mid-Miocene volcanic centers in eastern Oregon. These silicic centers, of which many erupted during regional flood basalt activity, represent crustal magmatism west of the Proterozoic cratonic lithosphere.

Sr isotopic data presented here are in large part inconsistent with previously determined locations for the MSL (0.7040) and CSL (0.7060) in eastern Oregon. Silicic centers over $100 \mathrm{~km}$ west of the proposed boundaries retain $\mathrm{Sr}$ isotope signatures significantly greater than 0.7040 , and in a few cases, even greater than 0.7060 . Discrepancies with these long established isotopic boundaries call into question how sharp the crustal transitions are or to what extent more radiogenic crustal domains exist west of the cratonic boundary. Leeman et al. (1992) describe these transitional zones as arising from a westward-dipping decollement at lithospheric mantle depths. This resulted in a $\sim 150-\mathrm{km}$-wide transition zone $\left(119^{\circ} \mathrm{W}-116.5^{\circ} \mathrm{W}\right)$ of mixed accreted oceanic lithosphere and cratonic subcontinental mantle, whereby the cratonic mantle portion progressively decreases westward, which raises a question regarding the likely causes for observed high $\mathrm{Sr}$ isotope ratios $(>0.7060)$ in rhyolites from vents located between $\sim 119^{\circ} \mathrm{W}$ to $\sim 117^{\circ} \mathrm{W}$ and $\sim 43^{\circ} \mathrm{N}$ to $\sim 44.5^{\circ} \mathrm{N}$.

\section{Position of Terrane/Craton Boundary}

The existence of crustal sources retaining Sr isotopic ratios $>0.7060$ west of the long accepted MSL could signify the following: 1) the position of the 0.7060 line, and 
therefore the position of the lithospheric boundary between accreted terranes to the west and cratonic crust to the east on the latitude between $43^{\circ} \mathrm{N}$ and $45^{\circ} \mathrm{N}$, is not where the MSL is currently positioned but rather should be moved westward, or 2) alternatively, crustally derived igneous rocks with $\mathrm{Sr}$ isotopic ratios $>0.7060$ are not as faithfully delineating the position of the accreted terrane/craton boundary as previously thought. In this regard, crustal rocks with ${ }^{87} \mathrm{Sr} /{ }^{86} \mathrm{Sr}_{\mathrm{i}}>0.7040$ may have even less to do with a transition from crust composed of accreted terranes to crust of North American craton. Geophysical evidence allows evaluation of these two possibilities. An increase in Moho depth occurs at the longitude coinciding with the CSL and MSL in the north and with the CSL in the south, except where there is a shallow Moho embayment trending eastward at $\sim 44^{\circ} \mathrm{N}$ (Eagar et al., 2011; Gilbert, 2012). Additional geophysical evidence indicates that the MSL does coincide with the lithospheric boundary based on resistivity models (Bedrosian and Feucht, 2013) and that more radiogenic crustal sections exist west of the MSL. This indicates that the location of the MSL does coincide with the transition of cratonic crust to the east and accreted terrane crust to the west.

Higher $\mathrm{Sr}$ ratios west of the MSL at latitudes above $43.5^{\circ} \mathrm{N}$ cannot be explained by a model incorporating a sliver of cratonic lithosphere underlying accreted terrane crust in eastern Oregon (Leeman et al., 1992; Evans et al., 2002). This is only applicable to the Owyhee plateau in southeastern Oregon where the CSL and MSL are separated. Further north, a shallow Moho at $\sim 30 \mathrm{~km}$ is also inconsistent with accreted terrane crust overlying craton that together would be in excess of $30 \mathrm{~km}$ (cf. Evans et al., 2002). The highest $\mathrm{Sr}$ ratios in the Littlefield/Cottonwood Mountain area are mirrored by $\mathrm{Sr}$ ratios 
around 0.704 on either side, requiring an indenter rather than a cratonic keel at $44^{\circ} \mathrm{N}$

(Figure 29). Lastly, results of this study are too geographically scattered to conform to a gradual E-W transition of ${ }^{87} \mathrm{Sr} /{ }^{86} \mathrm{Sr}_{\mathrm{i}}$ (Figure 29) and a mixed lithospheric mantle could not serve to explain higher $\mathrm{Sr}$ isotopic signatures in rhyolites that largely originated from crustal sources.

\section{Variable Accreted Terrane Crust}

Isotopic signatures of accreted terranes in eastern Oregon vary considerably

depending on rock type and origin. The Olds Ferry terrane has ${ }^{87} \mathrm{Sr} /{ }^{86} \mathrm{Sr}_{\mathrm{i}}$ ratios less radiogenic than metaplutonic rocks but more radiogenic than siliceous argillites of the Baker terrane. Accreted terrane outcrops only occur in the northern part of our study area (Figure 1), but lithologies of xenoliths found in volcanic rocks along the southern part indicate variable meta-sedimentary and igneous lithologies (Evans et al., 2002; Streck, 2002; J. Edwards, pers. comm. 2013) that suggest accreted terranes in the southern part were also composed of variable lithologies.

The northernmost primary terrane is the Wallowa terrane, although none of the units in this study are erupted through this terrane. Schwartz et al. (2010) propose the boundary between the Wallowa island-arc terrane and the Baker accretionary-complex terrane is an example of a broad zone of imbrication composed of slabs and slices of arc crust tectonically mixed within an accretionary complex. The northern margin of the Baker terrane includes the Bourne subterrane with metaplutonic rocks, Elkhorn Ridge Argillite, and Cougar Basin metasedimentary sequence. The metaplutonic rocks have low 
${ }^{87} \mathrm{Sr} /{ }^{86} \mathrm{Sr}_{\mathrm{i}}$ values $(0.7033$ to 0.7034$)$, the siliceous argillites from the chert-argillite mélange have ${ }^{87} \mathrm{Sr} /{ }^{86} \mathrm{Sr}_{\mathrm{i}}$ values between 0.7073 and 0.7094 , while the metasedimentary sequence has ${ }^{87} \mathrm{Sr} /{ }^{86} \mathrm{Sr}_{\mathrm{i}}$ values between 0.7039 and 0.7057 (Schwartz et al., 2010). Elevated ${ }^{87} \mathrm{Sr} /{ }^{86} \mathrm{Sr}_{\mathrm{i}}$ values of the Elkhorn Ridge Argillite indicate that it contains a component of detritus from Proterozoic or older continental crust in addition to volcanogenic material (Schwartz et al., 2010). Among the rhyolites analyzed in this study, both Dooley Mountain and Unity rhyolites have eruption locations within the area delineated as Baker terrane by LaMaskin et al. (2009). ${ }^{87} \mathrm{Sr} /{ }^{86} \mathrm{Sr}_{i}$ ratios for these units averaged 0.7046 and 0.7038 , respectively.

The southernmost terrane that lies below many of the sample locations is the Olds Ferry terrane. The Huntington Formation of the Olds Ferry terrane is split into an upper and lower member. Volcanic rocks of the upper Huntington are richer in silica and have elevated ${ }^{87} \mathrm{Sr} /{ }^{86} \mathrm{Sr}_{\mathrm{i}}$ ratios $(0.7036$ to 0.7057$)$ relative to samples from the lower Huntington Formation (Tumpane, 2010). Two samples from the lower Huntington Formation had ${ }^{87} \mathrm{Sr} /{ }^{86} \mathrm{Sr}_{\mathrm{i}}$ values of 0.7037 and 0.7034 (Tumpane, 2010). More radiogenic ${ }^{87} \mathrm{Sr} /{ }^{86} \mathrm{Sr}_{\mathrm{i}}$ compositions of the upper Huntington and Weatherby Formation likely reflect the increasing influence of continental crust incorporation or lithospheric mantle transitions to more radiogenic values on volcanic rocks through time (Tumpane, 2010). 


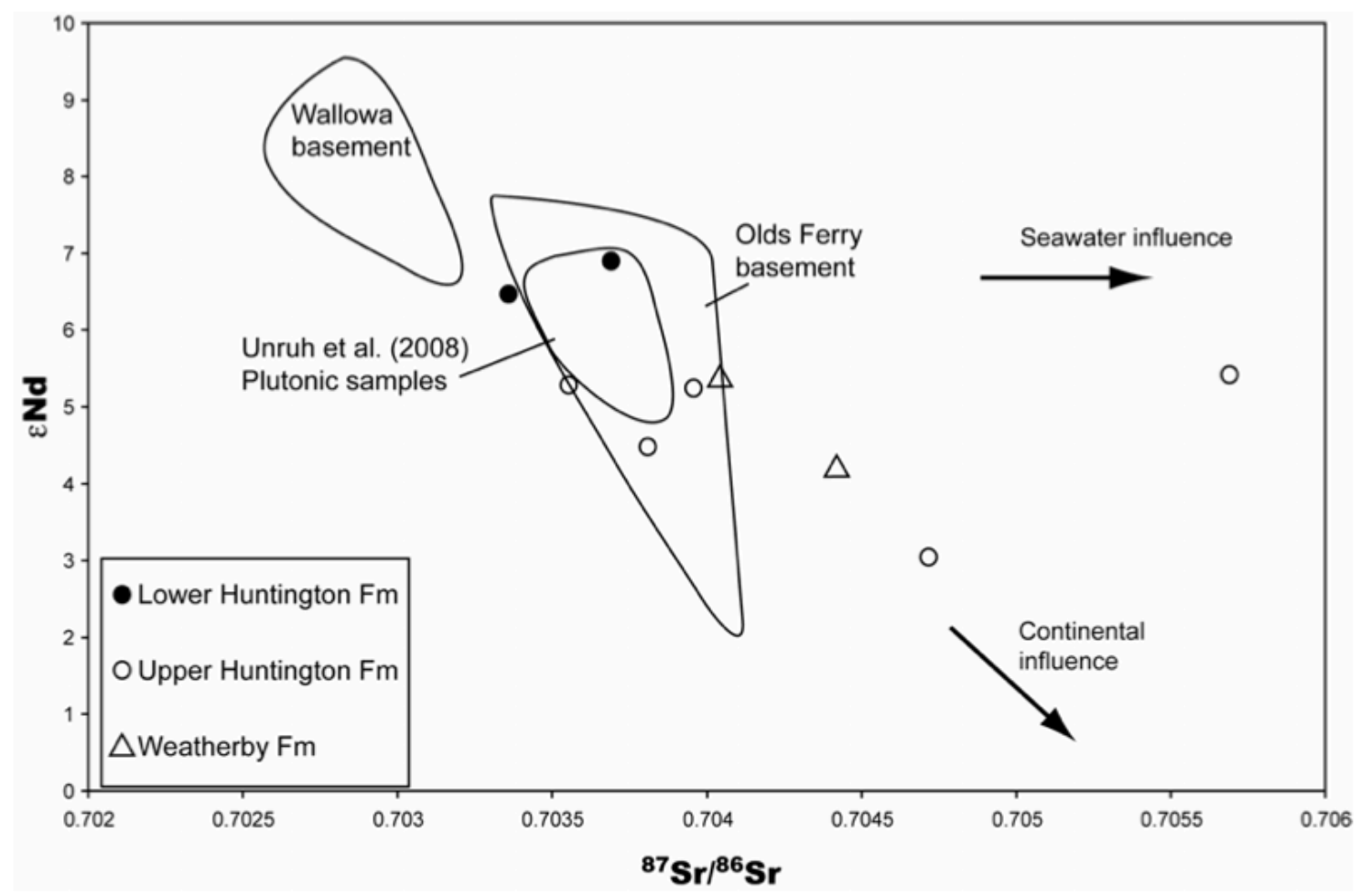

Figure 30. ${ }^{87} \mathrm{Sr} /{ }^{86} \mathrm{Sr}_{\mathrm{i}}-\varepsilon N d$ diagram showing fields for basement rocks of the Olds Ferry and Wallowa terranes (from Tumpane, 2010). Both sets of basement rocks have ${ }^{87} \mathrm{Sr}^{86} \mathrm{Sr}_{\mathrm{i}}$ and $\varepsilon N d$ values indicative of an island arc setting and little evidence for elevated ${ }^{87} \mathrm{Sr}^{86} \mathrm{Sr}_{\mathrm{i}}$ ratios.

The Izee terrane is marine sedimentary rocks that rest in depositional contact on older rocks and structures of the Baker, Wallowa, and Olds Ferry terranes (Dorsey and LaMaskin, 2007). A marine strata section $\sim 12-15 \mathrm{~km}$ thick preserves the sequences of rocks deposited in a single large marine basin to form the Izee terrane (Dorsey and LaMaskin, 2007). Sedimentation to the Izee basin was derived in part by material shedding from the craton, which should imprint a ${ }^{87} \mathrm{Sr}^{86} \mathrm{Sr}_{\mathrm{i}}$ signal of greater than 0.706 . Rather than a progressive decrease of ${ }^{87} \mathrm{Sr} /{ }^{86} \mathrm{Sr}_{\mathrm{i}}$ away from the craton boundary, $\mathrm{Sr}$ isotopic ratios show no consistent trend and placing Sr contours in these regions indicates complicated curved paths and a patchy distribution of similar Sr isotopic values (Figure 29). These trends are better explained by the orientation of accreted terrane boundaries 
and expected local complications in the distribution of the terrane rocks with high vs. low Sr isotopic values rather than by the progressive thinning of cratonic crust westward.

As a result of this distribution of isotopic values and the highly variable isotopic nature of the accreted terranes, the crustal composition of a specific terrane in a particular area is most likely the primary control on observed ${ }^{87} \mathrm{Sr} /{ }^{86} \mathrm{Sr}_{\mathrm{i}}$. One consequence of this is that not all fractionated basalts with elevated radiogenic ratios would have had to inherit these signatures from cratonic crust. In contrast, some may have inherited such signatures from specific radiogenic accreted terranes or parts of terranes. Based in part on high ${ }^{87} \mathrm{Sr} /{ }^{86} \mathrm{Sr}_{\mathrm{i}}$ of Grande Ronde lavas (0.7041 - 0.7057), Wolff et al. (2008) regarded these lavas as essentially Imnaha basaltic magmas $\left({ }^{87} \mathrm{Sr} /{ }^{86} \mathrm{Sr}_{\mathrm{i}}=0.7038-0.7044\right)$ that were more extensively contaminated by cratonic crust. It was also proposed that both Grande Ronde and Imnaha Basalts were derived from a single central crustal magma system that was centered in the area where the western Snake River Plain, Oregon-Idaho graben, and Chief Joseph dike swarm converge (Wolff et al., 2008; Wolff and Ramos, 2013). This area coincides with rhyolites with the highest ${ }^{87} \mathrm{Sr} /{ }^{86} \mathrm{Sr}_{\mathrm{i}}$ as well as surrounding centers (Figure 29). Given this spatial overlap, it is plausible that some of isotopic change observed in Grande Ronde Basalt relative to Imnaha Basalt could possibly also result from the incorporation of highly radiogenic, accreted terrane crust during storage in magma chambers located within specific regions of highly radiogenic accreted terranes. 


\section{Variations Induced by Variable Amounts of Basalt Ancestry}

Not all rhyolites may be pure crustal melts and the possibility exists that basaltic magma contributed, at least in part, to their compositions. Rhyolites from the Snake River Plain have radiogenic isotopic ratios that lie between those of surrounding crust and of regional basaltic magma (Christiansen and McCurry, 2008; Leeman et al., 2008). This has been interpreted as evidence that these rhyolites obtained isotopic signatures by combined processes such as Assimilation-Fractionation Crystallization (AFC) or other mixing processes. For rhyolites in this study, $\mathrm{Sr}$ isotopic ratios could hypothetically become either more or less radiogenic by mixing with mafic magma. This results from the largest pool of mafic magma that is in fact contemporaneous with 16-15 Ma rhyolites is the basaltic-andesitic magmas of the Grande Ronde Basalt, which have isotopic $\mathrm{Sr}$ ratios ranging between $0.7041-0.7057$ and are thought to have been stored at crustal levels over most of the area of this study (Wolff et al., 2008; Wolff and Ramos, 2013; Streck et al., submitted). If mafic magmas with $\mathrm{Sr}$ isotopic ratios of $>0.7040$ interacted with less radiogenic accreted crust (0.7036), the resulting $\mathrm{Sr}$ isotopic ratio of the mixture would be higher than a pure crustal melt $(\sim 0.7036)$. One possible example of this is the Dinner Creek Tuff. The five Dinner Creek Tuff samples analyzed in this study have an average ${ }^{87} \mathrm{Sr} /{ }^{86} \mathrm{Sr}_{\mathrm{i}}$ of $0.7043 \pm 0.0002$, but the likely source area is surrounded by rhyolites with $\mathrm{Sr}$ isotopic ratios of $0.7033-0.7039$. Additional evidence that this occurred is found in co-eruptive mafic components that are interpreted as de facto Grand Ronde Basalt (Streck et al., submitted). 
An alternative scenario in lowering Sr isotope ratios of rhyolites could result from interaction of mafic magmas such as Imnaha $\left({ }^{87} \mathrm{Sr}^{86} \mathrm{Sr}_{\mathrm{i}}=0.7038-0.7044\right)$ or Steens Mountain $\left({ }^{87} \mathrm{Sr} /{ }^{86} \mathrm{Sr}_{\mathrm{i}}=0.7033-0.7040\right)$ type basalts (cf. Wolff and Ramos, 2013) with more radiogenic crust like the one that is assumed to be tapped for the Littlefield/ Cottonwood Mountain rhyolites (i.e. with ${ }^{87} \mathrm{Sr} /{ }^{86} \mathrm{Sr}_{\mathrm{i}}>0.706$ ). We speculate that variable amounts of a "basalt component" in rhyolites play a secondary role in contrasting specific Sr isotopic ratios of compositionally variable accreted terrane crust.

Lees (1994) modeled the Dinner Creek Tuff and Upper and Lower Members of Littlefield Rhyolite to determine whether regional basalts are genetically related to the rhyolites. The Malheur Group basalt fractionation model effectively reproduces the composition of the Upper Littlefield Rhyolite by fractional crystallization of clinopyroxene, plagioclase, and ilmenite (Lees, 1994). Beginning with the Hunter Creek Basalt, approximately $50 \%$ fractionation is required to obtain the Upper Littlefield Rhyolite composition for most trace elements ( $\mathrm{Zr}, \mathrm{Rb}, \mathrm{Ba}, \mathrm{Nb}, \mathrm{Sr}, \mathrm{Y}$ and $\mathrm{TiO}_{2}$ ), corresponding to about a 10\% rise in silica (Lees, 1994). To achieve an additional $8 \%$ increase in silica and reach the $\mathrm{SiO}_{2}$ composition of the rhyolite, about $70 \%$ of fractional crystallization is required. In addition, the similarity of ${ }^{87} \mathrm{Sr} /{ }^{86} \mathrm{Sr}_{\mathrm{i}}$ isotope ratios of the Upper Littlefield Rhyolite $\left({ }^{87} \mathrm{Sr} /{ }^{86} \mathrm{Sr}_{\mathrm{i}}=0.7056\right)$ and the more contaminated Hunter Creek Basalt flows $\left({ }^{87} \mathrm{Sr} /{ }^{86} \mathrm{Sr}_{\mathrm{i}}=0.7044\right.$ to 0.7056$)$ confirm the idea that the Upper Littlefield Rhyolite is related to the Malheur Gorge basalts by fractionation (Lees, 1994). Yet, the Dinner Creek Tuff and the Lower Littlefield Rhyolite were not able to be successfully modeled using crystal fractionation of Malheur Group basalts and therefore are not 
genetically related to the Malheur Group basalts. Therefore, they may have an origin from crustal melting (Lees, 1994). The high ${ }^{87} \mathrm{Sr}^{86} \mathrm{Sr}_{\mathrm{i}}=0.7069$ of the Lower Littlefield Rhyolite also suggests the Lower Littlefield Rhyolite Member has a different origin than that of the Upper Littlefield Rhyolite Member, such as crustal melting (Lees, 1994).

\section{Lead Isotopes}

Because the accreted terranes that exist west of the MSL were extracted from the mantle during Paleozoic time, they are too young to have developed significant $\mathrm{Pb}$ isotope contrasts with present-day mantle sources (Wolff and Ramos, 2013). While Pb isotope data is incomplete for all samples of this study, the available data indicate a significant range in $\mathrm{Pb}$ isotopes. Yet, data of individual regions tend to plot close to one another in comparison to entire data spread (Figure 25).

(a)

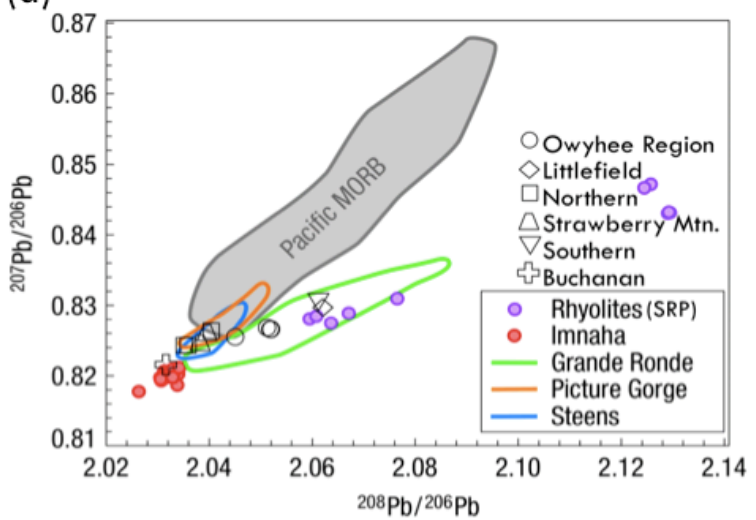

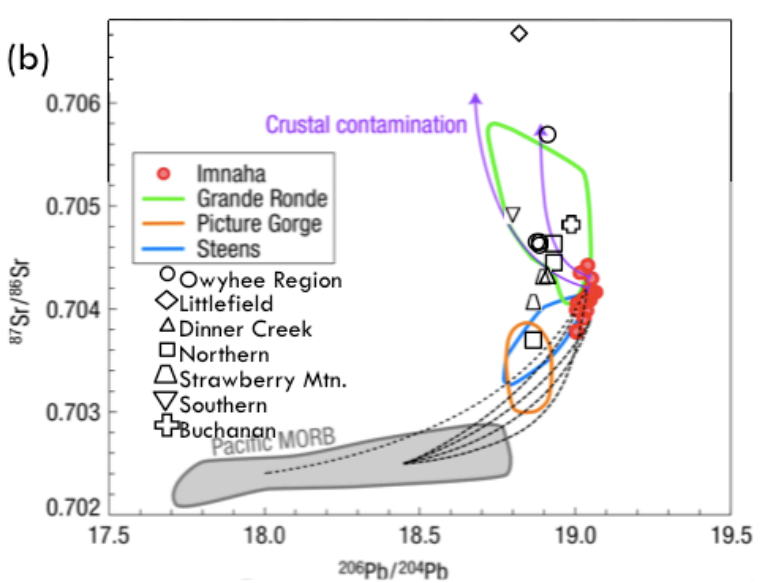

Figure 31. Sr-Pb isotope diagrams illustrating relations among CRBG lavas and Pacific mid-oceanridge basalts (after Wolff et al., 2008) with rhyolites from this study. (a) ${ }^{207} \mathrm{~Pb} /{ }^{206} \mathrm{~Pb}$ versus ${ }^{208} \mathrm{~Pb} /{ }^{206} \mathrm{~Pb}$ and (b) ${ }^{87} \mathrm{Sr} /{ }^{86} \mathrm{Sr}_{\mathrm{i}}$ versus ${ }^{206} \mathrm{~Pb} /{ }^{204} \mathrm{~Pb}$. Black dotted lines are mixtures between Imnaha-source mantle and depleted mantle (Wolff et al., 2008). Plum-colored arrows labeled "crustal contamination" represent the extent of interaction between Imnaha magmas and crust, which is represented by rhyolite lavas in the vicinity of the CRBG magma storage zone (Wolff et al., 2008). 
Samples from this study are compared to a more regional view in Figure 31. For the most part, the samples fall within the boundaries of the main-phase CRBG lavas. MSLFR1 (Littlefield Rhyolite) and EJ-12-13B (Jump Creek rhyolite) fall outside of the Grande Ronde field in Figure 31b, but they follow the arrow pathway of crustal contamination. Overall, the rhyolites have both craton and accreted terrane trends, but most rhyolites are similar to the Grande Ronde trend.

\section{Oxygen Isotopes}

Silicate minerals in rocks of the crust of the Earth are in general enriched in ${ }^{18} \mathrm{O}$ whereas meteoric water and seawater on the surface of the Earth are depleted. As a result, the isotope composition of oxygen in igneous rocks may be altered by isotope-exchange reactions with water at elevated temperatures (Faure, 2001). Two models have been proposed to explain low $\delta^{18} \mathrm{O}$ for rhyolites of the Snake River Plain-Yellowstone hotspot trend. These models differ on the timing of protolith alteration, depth at which alteration occurs, and physical controls on the extent of alteration. The first model involves a single caldera system or multiple, near contemporaneous, overlapping systems. In this scenario, the earliest erupted products become hydrothermally altered and are subsequently melted at shallow depths during cyclical volcanism at the same or overlapping eruptive centers to form low $\delta^{18} \mathrm{O}$ rhyolites (Bindeman and Valley, 2001; Watts et al., 2011). Evidence of

small to dramatic $\left(>5 \%\right.$ o) $\delta^{18} \mathrm{O}$ depletions occur in magmas from Yellowstone that erupted after caldera-forming eruptions (Bindeman and Valley, 2001). In the Yellowstone Volcanic Plateau, the majority of erupted products are normal $\delta^{18} \mathrm{O}$ rhyolites while low- 
$\delta^{18} \mathrm{O}$ units are primarily small volume lavas erupted following episodes of caldera collapse.

The second model involves a pre-existing crustal magma that was hydrothermally altered a significant amount of time prior to the onset of Miocene magmatism (Boroughs et al., 2012). Boroughs et al. (2005) determined hydrothermally altered zones of the granitic crust of the Idaho batholith could be a pre-existing low $\delta^{18} \mathrm{O}$ source to generate low $\delta^{18} \mathrm{O}$ rhyolites upon melting in the volcanic fields associated with the magmas of the Snake River Plain.

The low $\delta^{18} \mathrm{O}$ of selected rhyolites of this study cannot be explained by either of these models. The locations of the silicic centers are too far west of the Cretaceous plutons of the Idaho Batholith to be explained by remelting of these pre-existing low $\delta^{18} \mathrm{O}$ Idaho Batholith sources. The lowest oxygen ratios come from EJ-12-17 (Rhyolite of Bully Creek, $\delta^{18} \mathrm{O}_{\text {plag }}=1.6 \%$ ) and MS-LFR1 (Littlefield Rhyolite, $\delta^{18} \mathrm{O}_{\text {plag }}=1.8 \%$ ), which erupted $\sim 80 \mathrm{~km}$ west of the cratonic margin. The model of remelting of altered silicic rocks at centers of multiple, confocal caldera cycles is irreconcilable because there is no evidence of multiple caldera cycles at any of the locations where we observe low $\delta^{18} \mathrm{O}$ values. Hydrothermal alternation of terrane rocks, as opposed to Cretaceous plutons of the Idaho Batholith, prior to melting may explain the low $\delta^{18} \mathrm{O}$ values of this study. 


\section{CONCLUSIONS}

This study presents new data for $\mathrm{Sr}, \mathrm{Pb}$, and $\mathrm{O}$ isotopes of mostly mid-Miocene rhyolites erupted in eastern Oregon as well as new ${ }^{40} \mathrm{Ar} /{ }^{39} \mathrm{Ar}$ ages for a number of silicic centers throughout the region. These silicic centers, which formed contemporaneously with regional flood basalt activity, represent mantle and crustal magmatism west of the Proterozoic cratonic lithosphere and the Mesozoic accreted terrains lithospheric transition. Sr isotopic analyses of twenty-seven Miocene rhyolites and dacites in eastern Oregon confirms the presence of high and variable ${ }^{87} \mathrm{Sr} /{ }^{86} \mathrm{Sr}_{\mathrm{i}}$ ratios that are not consistent with the current location of the MSL (0.7040) and CSL (0.7060) boundaries. This suggests that the craton-accreted terrane boundary may not be as well defined isotopically as previously thought and that second order crustal variations westward of the craton are likely responsible for this discrepancy. Instead of elevated ${ }^{87} \mathrm{Sr} /{ }^{86} \mathrm{Sr}_{\mathrm{i}}$ variations arising from a westward-dipping decollement as suggested by Leeman et al. (1992), we suggest that the primary control is the crustal composition of accreted terranes of specific areas of eastern Oregon. Secondary control on observed ${ }^{87} \mathrm{Sr}^{86} \mathrm{Sr}_{\mathrm{i}}$ ratios is possibly associated with the amount of basalt involved in the generation of these rhyolites. Because ${ }^{87} \mathrm{Sr} /{ }^{86} \mathrm{Sr}_{\mathrm{i}}$ ratios in the contemporaneous mafic magmas of the CRBG vary considerably, changing the type and amount of this "basalt component" in rhyolites in eastern Oregon could generate high or low $\mathrm{Sr}$ isotope ratios relative to the surrounding crust.

$\mathrm{Pb}$ isotopes also vary, though data of individual rhyolites from the same region are similar to one another relative to entire data spread. In comparison to $\mathrm{Sr}$ and $\mathrm{Pb}$ 
isotope relations among the main-phase CRBG lavas, samples from this study tend to lie along the boundaries of the Grande Ronde, Picture Gorge, and Steens basalts, though samples from the Littlefield Rhyolite and Jump Creek rhyolite lie along trends of crustal contamination (Figure 31). Continued $\mathrm{Pb}$ isotope analysis of mid-Miocene silicic volcanic rocks from eastern Oregon would allow for a more robust data set to generate further conclusions.

There is a significant range in oxygen isotopes in samples from this study area, with the approximate bulk rock $\delta^{18} \mathrm{O}$ values ranging from 2.1 to $10.5 \%$. The lowest $\delta^{18} \mathrm{O}$ samples are from the Littlefield Rhyolite. Low $\delta^{18} \mathrm{O}$ values document high temperature interaction of magmatic protoliths with meteoric waters. Yet, the locations of these units do not conform to the hypothesized models of producing low $\delta^{18} \mathrm{O}$ rhyolites. There must be another cause at play to generate these low $\delta^{18} \mathrm{O}$ units. Hydrothermal alteration of terrane rocks prior to melting may explain the low $\delta^{18} \mathrm{O}$ values of this study. 


\section{REFERENCES}

Armstrong, R.L., Taubeneck, W.H., and Hales, P.O., 1977, Rb-Sr and K-Ar geochronometry of Mesozoic granitic rocks and their $\mathrm{Sr}$ isotopic composition, Oregon, Washington, Idaho: Geological Society of America Bulletin, v. 88, p. $397-411$.

Barry, T.L., Kelley, S.P., Reidel, S., Camp, V., Self, S., Jarboe, N., Duncan, R., and Renne, P., 2013, Eruption chronology of the Columbia River Basalt Group, in Reidel, S.P., Camp, V.E., Ross, M.E., Wolff, J.A., Martin, B.S., Tolan, T.L., and Wells, R.E., eds., The Columbia River Flood Basalt Province, Volume 497, Geological Society of America Special Paper, p. 45-66.

Bedrosian, P.A., and Feucht, D.W., 2013, Structure and tectonics of the northwestern United States from EarthScope USArray magnetotelluric data: Earth and Planetary Science Letters, v. 402, p. 275-289.

Bindeman, I.N., Ponomareva, V.V., Bailey, J.C., and Valley, J.W., 2004, Volcanic arc of Kamchatka: a province with high- $\delta^{18} \mathrm{O}$ magma sources and large-scale ${ }^{18} \mathrm{O} /{ }^{16} \mathrm{O}$ depletion of the upper crust: Geochimica et Cosmochimica Acta, v. 68, p. 841865.

Bindeman, I.N., and Valley, J.W., 2001, Low- $\delta^{18}$ O rhyolites from Yellowstone: magmatic evolution based on analyses of zircons and individual phenocrysts: Journal of Petrology, v. 8, p. 1491-1517.

-, 2002, Oxygen isotope study of the Long Valley magma system, California: isotope thermometry and convection in large silicic magma bodies: Contributions to Mineralogy and Petrology, v. 144, p. 185-205.

-, 2003, Rapid generation of both high- and low- $\delta{ }^{18} \mathrm{O}$, large-volume silicic magmas at the Timber Mountain/Oasis Valley caldera complex, Nevada: Geological Society of America Bulletin, v. 115, no. 5, p. 581-595.

Boroughs, S., Wolff, J.A., Bonnichsen, B., Godchaux, M., and Larson, P.B., 2005, Largevolume, low- $\delta{ }^{18} \mathrm{O}$ rhyolites of the central Snake River Plain, Idaho, USA: Geology, v. 33, no. 10, p. 821-824.

Boroughs, S., Wolff, J.A., Ellis, B.S., Bonnichsen, B., and Larson, P.B., 2012, Evaluation of models for the origin of Miocene low- $-{ }^{18} \mathrm{O}$ rhyolites of the Yellowstone/ 
Columbia River Large Igneous Province: Earth and Planetary Science Letters, v. 313-314, p. 45-55.

Brooks, H.C., 1979, Plate tectonics and the geologic history of the Blue Mountains: Oregon Geology, v. 41, p. 71-80.

Brooks, H.C., and Vallier, T.L., 1978, Mesozoic rocks and tectonic evolution of eastern Oregon and western Idaho, in Howell, D.G., and McDougall, K.A., eds., Mesozoic paleogeography of the Western United States, Pacific Coast Paleogeography Symposium 2, Volume Pacific Section: Los Angeles, Society of Economic Paleontologists and Mineralogists, p. 133-146.

Brownlow, A.H., 1995, Geochemistry, New Jersey, Prentice-Hall, Inc., 580 p.

Brueseke, M.E., Hart, W.K., and Heizler, M.T., 2008, Diverse mid-Miocene silicic volcanism associated with the Yellowstone-Newberry thermal anomaly: Bulletin of Volcanology, v. 70, p. 343-360.

Camp, V.E., 2013, Origin of Columbia River Basalt: Passive rise of shallow mantle, or active upwelling of a deep-mantle plume?, in Reidel, S.P., Camp, V.E., Ross, M.E., Wolff, J.A., Martin, B.S., Tolan, T.L., and Wells, R.E., eds., The Columbia River Flood Basalt Province, Volume 497, Geological Society of America Special Paper, p. 181-199.

Camp, V.E., and Ross, M.E., 2004, Mantle dynamics and genesis of mafic magmatism in the intermontane Pacific Northwest: Journal of Geophysical Research, v. 109, 14 p.

Camp, V.E., Ross, M.E., and Hanson, W.E., 2003, Genesis of flood basalts and Basin and Range volcanic rocks from Steens Mountain to the Malheur River Gorge, Oregon: Geological Society of America Bulletin, v. 115, p. 105-128.

Christiansen, E.H., and McCurry, M., 2008, Contrasting origins of Cenozoic silicic volcanic rocks from the western Cordillera of the United States: Bulletin of Volcanology, v. 70, p. 251-267.

Christiansen, R.L., Foulger, G.R., and Evans, J.R., 2002, Upper-mantle origin of the Yellowstone hotspot: Geological Society of America Bulletin, v. 114, p. 12451256. 
Christiansen, R.L., and Yeats, R.L., 1992, Post-Laramide geology of the U.S. Cordillerian region, in Burchfiel, B.C., Lipman, P.W., and Zoback, M.L., eds., The Cordillerian Orogen: Conterminous U.S., Volume Geology of North America, G-3: Boulder, CO, Geological Society of America, p. 261-406.

Coble, M.A., and Mahood, G.A., 2012, Initial impingement of the Yellowstone plume located by widespread silicic volcanism contemporaneous with Columbia River flood basalts: Geology, v. 4, p. 655-658.

Cummings, M.L., Evans, J.G., Ferns, M.L., and Lees, K.R., 2000, Stratigraphic and structural evolution of the middle Miocene synvolcanic Oregon-Idaho graben: Geological Society of America Bulletin, v. 112, no. 5, p. 668-682.

DeCelles, P.G., 2004, Late Jurassic to Eocene evolution of the Cordilleran thrust belt and foreland basin system, western U.S.A.: American Journal of Science, v. 304, p. 105-168.

Dickinson, W.R., 2004, Evolution of the North American Cordillera: Annual Review of Earth and Planetary Sciences, v. 32, p. 13-45.

Dorsey, R.J., and LaMaskin, T.A., 2007, Stratigraphic record of Triassic-Jurassic collisional tectonics in the Blue Mountains Province, northeastern Oregon: American Journal of Science, v. 307, p. 1167-1193.

Duncan, R.A., and Keller, R.A., 2004, Radiometric ages for basement rocks from the Emperor Seamounts, ODP Leg 197: Geochemistry Geophysics Geosystems, v. 5, no. $8,13 \mathrm{p}$.

Eagar, K.C., Fouch, M.J., James, D.E., and Carlson, R.W., 2011, Crustal structure beneath the High Lava Plains of eastern Oregon and surrounding regions from receiver function anaylsis: Journal of Geophysical Research, v. 116, 18 p.

Evans, J.G., and Binger, G.B., 1999, Geologic map of the Little Black Canyon quadrangle, Malheur County, Oregon, scale 1:24 000.

Evans, J.G., Griscom, A., Halvorson, P.F., and Cummings, M.L., 2002, Tracking the western margin of the North American craton beneath southeastern Oregon: A multidisciplinary approach, in Bonnichsen, B., White, C.M., and McCurry, M., eds., Tectonic and Magmatic Evolution of the Snake River Plain Volcanic Province, Volume Bulletin 30: Moscow, Idaho, Idaho Geological Survey Press, p. 35-57. 
Faure, G., 2001, Origin of Igneous Rocks: The Isotopic Evidence, Berlin, Germany, Springer-Verlag, $495 \mathrm{p}$.

Faure, G., and Mensing, T.M., 2005, Isotopes Principles and Applications, Hoboken, New Jersey, John Wiley \& Sons, Inc., 896 p.

Faure, G., and Powell, J.L., 1972, Strontium Isotope Geology, Berlin, Germany, Springer-Verlag, Minerals, Rocks and Inorganic Materials, 188 p.

Ferns, M.L., and Brooks, H.C., 1995, The Bourne and Green subterranes of the Baker terrane, northeastern Oregon: Implications for the evolution of the Blue Mountains island-arc system, in Vallier, T.L., and Brooks, H.C., eds., Geology of the Blue Mountains region of Oregon, Idaho, and Washington: Petrology and tectonic evolution of pre-tertiary rocks of the Blue Mountains region, Volume Professional Paper 1438, U.S. Geological Survey, p. 331-358.

Ferns, M.L., Brooks, H.V., Evans, J.G., and Cummings, M.L., 1993, Geologic map of the Vale 30' x 60' quadrangle, Malheur County, Oregon and Owyhee County, Idaho, scale 1:100 000 .

Ferns, M.L., and McClaughry, J.D., 2013, Stratigraphy and volcanic evolution of the middle Miocene La Grande - Owyhee eruptive axis in eastern Oregon, in Reidel, S.P., Camp, V.E., Ross, M.E., Wolff, J.A., Martin, B.S., Tolan, T.L., and Wells, R.E., eds., The Columbia River Flood Basalt Province, Volume 497, Geological Society of America Special Paper, p. 401-472.

Fleck, R.J., and Criss, R.E., 1985, Strontium and oxygen isotope variations in Mesozoic and Tertiary plutons of central Idaho: Contributions to Mineralogy and Petrology, v. 90, p. 291-308.

Fleck, R.J., and Criss, R.E., 2004, Location, age, and tectonic significance of the Western Idaho Suture Zone (WISZ): U.S. Geological Survey Open-File Report, v. 2004$1039,48 \mathrm{p}$.

Fleck, R.J., Sutter, J.F., and Elliot, D.H., 1977, Interpretation of discordant ${ }^{40} \mathrm{Ar} /{ }^{39} \mathrm{Ar}$ agespectra of Mesozoic tholeiites from Antartica: Geochimica et Cosmochimica Acta, v. 41, p. 15-32.

Ford, M.T., 2011, Rhyolitic magmatism of the High Lava Plains and adjacent northwest Basin and Range, Oregon: implications for the evolution of continental crust [Ph.D. thesis]: Corvallis, Oregon State University, 314 p. 
Ford, M.T., Grunder, A.L., and Duncan, R.A., 2013, Bimodal volcanism of the High Lava Plains and northwestern Basin and Range of Oregon: the distribution and tectonic implications of age-progressive rhyolites: Geochemistry Geophysics Geosystems, v. 14, no. 8, p. 2836-2857.

Gilbert, H., 2012, Crustal structure and signatures of recent tectonism as influenced by ancient terranes in the western United States: Geosphere, v. 8, no. 1, p. 141-157.

Gilluly, J., 1937, Geology and mineral resources of the Baker Quadrangle, Oregon: USGS Bulletin, v. 879, 119 p.

Henry, C.D., Castor, S.B., McIntosh, W.C., Heizler, M.T., Cuney, M., and Chemillac, R., 2006, Timing of oldest Steens Basalt magmatism from precise dating of silicic volcanic rocks, McDermitt Caldera and Northwest Nevada Volcanic Field: American Geophysical Union, Fall Meeting 2006, abstract \#V44C-08.

Hooper, P.R., Binger, G.B., and Lees, K.R., 2002, Ages of the Steens and Columbia River flood basalts and their relationship to extension-related calcalkalic volcanism in eastern Oregon: Geological Society of America Bulletin, v. 114, p. 43-50.

Hughes, S.S., and McCurry, M., 2002, Bulk major and trace element evidence for a timespace evolution of Snake River Plain rhyolites, Idaho, in Bonnichsen, B., White, C.M., McCurry, Micheal, eds., Tectonic and Magmatic Evolution of the Snake River Plain Volcanic Province, Volume 30: Idaho, Idaho Geological Survey Bulletin, p. 161-171.

Johnson, D.M., Hooper, P.R., and Conrey, R.M., 1999, XRF analysis of rocks and minerals for major and trace elements on a single low dilution Li-tetraborate fused bead: Advances in X-ray Analysis, v. 41, p. 843-867.

Kays, M.A., Ferns, M.L., and Brooks, H.C., 1987, Metamorphism of Triassic-Paleozoic belt rocks--A guide to field and petrologic relations in the oceanic mélange, Klamath and Blue Mountains, California and Oregon, in Ernst, W.G., ed., Metamorphism and crustal evolution of the Western United States, Volume Rubey Volume VII: Englewood Cliffs, New Jersey, Prentice-Hall, p. 1098-1120.

Kistler, R.W., and Peterman, Z.E., 1978, Reconstruction of crustal California on the basis of initial strontium isotopic compositions of Mesozoic granitic rocks: U.S. Geological Survey Professional Paper, v. 107, 17 p. 
Kittleman, L.R., Green, A.R., Haddock, G.H., Hagood, A.R., Johnson, A.M., McMurray, J.M., Russell, R.G., and Weeden, D.A., 1967, Geologic map of the Owyhee region, Malheur County, Oregon: University of Oregon Museum of Natural History, scale 1:125 000.

Knaack, C., Cornelius, S., and Hooper, P.R., 1994, Trace element analysis of rocks and minerals by ICP-MS: Washington State University, 18 p.

Koppers, A.A.P., 2002, ArArCALC- software for 40Ar/39Ar age calculations: Computers and Geosciences, v. 28, no. 5, p. 605-619.

Kuiper, K.F., Deino, A., Hilgen, F.J., Krijgsman, W., Renne, P.R., and Wijbrans, J.R., 2008, Synchronizing rock clocks of earth history: Science, v. 320, p. 500-504.

LaMaskin, T.A., 2009, Stratigraphy, provenance, and tectonic evolution of Mesozoic basins in the Blue Mountains Province, eastern Oregon and western Idaho [Ph.D. thesis]: Eugene, University of Oregon, 232 p.

LaMaskin, T.A., Schwartz, J.J., Dorsey, R.J., Snoke, A.W., Johnson, K., and Vervoort, J.D., 2009, Mesozoic sedimentation, magmatism, and tectonics in the Blue Mountains Province, northeastern Oregon, in O'Connor, J.E., Dorsey, R.J., and Madin, I.P., eds., Volcanoes to Vineyards: Geologic Field Trips through the Dynamic Landscape of the Pacific Northwest: Field Guide 15, Geological Society of America, p. 187-202.

Le Bas, M.J., Le Maitre, R.W., Streckeisen, A., and Zanettin, B., 1986, A chemical classification of volcanic rocks based on the total alkali - silica diagram: Journal of Petrology, v. 27, p. 745-750.

Leeman, W.P., Annen, C., and Dufek, J., 2008, Snake River Plain - Yellowstone silicic volcanism: implications for magma genesis and magma fluxes: Geological Society Special Publication, v. 304, p. 235-260.

Leeman, W.P., Oldow, J.S., and Hart, W.K., 1992, Lithosphere-scale thrusting in the western U.S. Cordillera as constrained by $\mathrm{Sr}$ and $\mathrm{Nd}$ isotopic transitions in Neogene volcanic rocks: Geology, v. 20, p. 63-66.

Leeman, W.P., and Whelan, J.F., 1983, Oxygen and strontium isotopic studies of basaltic lavas from the Snake River Plain, Idaho: U.S. Geological Survey Open-File Report, v. 83, no. 338, 34 p. 
Lees, K.R., 1994, Magmatic and tectonic changes through time in the Neogene volcanic rocks of the Vale area, Oregon, northwestern USA [Ph.D.]: Milton Keynes, UK, Open University, 284 p.

Ma, L., Madin, I.P., Olson, K.V., and Watzig, R.J., 2009, Oregon geologic data compilation: Portland, Oregon, Oregon Department of Geology and Mineral Industries.

Maniar, P.D., and Piccoli, P.M., 1989, Tectonic distribution of granitoids: Geological Society of America Bulletin, v. 101, p. 635-643.

Marcy, P.I., Streck, M.J., and Ferns, M.L., 2013, Revisiting volcanology and composition of rhyolites and associated REE rich mafic clasts of the Three Fingers Caldera, SE Oregon: Geological Society of America Abstracts with Programs, v. 45, no. 6.

McDougall, I., 1976, Geochemistry and origin of basalt of the Columbia River Group, Oregon and Washington: Geological Society of America Bulletin, v. 87, 16 p.

Pierce, K.L., and Morgan, L.A., 1992, The track of the Yellowstone hot spot: volcanism, faulting, and uplift, in Link, P.K., Kuntz, M.A., Platt, L.B., eds., Regional Geology of eastern Idaho and western Wyoming, Volume 179, Geological Society of America Memoir, $53 \mathrm{p}$.

Pierce, K.L., and Morgan, L.A., 2009, Is the track of the Yellowstone hotspot driven by a deep mantle plume? Review of volcanism, faulting, and uplift in light of new data: Journal of Volcanology and Geothermal Research, v. 188, 25 p.

Pringle, M.S., 1993, Age progressive volcanism in the Musicians Seamounts: a test of hot spot hypothesis for the late Cretaceous Pacific, in Pringle, M.S., Sager, W.W., Sliter, W.V., and Stein, S., eds., The Mesozoic Pacific: Geology, Tectonics, and Volcanism: Washington D.C., American Geophysical Union, p. 279-305.

Rudnick, R.L., and Gao, S., 2003, The Composition of the Continental Crust, in Rudnick, R.L., ed., In The Crust: Oxford, Elsevier-Pergamon, v. 3, 64 p.

Savov, I.P., Leeman, W.P., Lee, C.-T.A., and Shirey, S.B., 2009, Boron isotopic variations in NW USA rhyolites: Yellowstone, Snake River Plain, Eastern Oregon: Journal of Volcanology and Geothermal Research, v. 188, p. 162-172.

Schwartz, J.J., Snoke, A.W., Frost, C.D., Barnes, C.G., Gromet, L.P., and Johnson, K., 2010, Analysis of the Wallowa-Baker terrane boundary: Implications for tectonic 
accretion in the Blue Mountains province, northeastern Oregon: Geological Society of America Bulletin, v. 122, p. 517-536.

Shervais, J.W., and Hanan, B.B., 2008, Lithosperic topography, tilted plumes, and the track of the Snake River - Yellowstone hot spot: Tectonics, v. 27, 17 p.

Steiner, A., and Streck, M.J., 2013, The Strawberry Volcanics: generation of 'orogenic' andesites from tholeiite within an intra-continental volcanic suite centred on the Columbia River flood basalt province, USA, in Gómez-Tuena, A., Straub, S.M., and Zellmer, G.F., eds., Orogenic andesites and crustal growth, Volume 385, Geological Society of London, p. 281-302.

Streck, M.J., 2002, Partial melting to produce high-silica rhyolites of a bimodal suite: compositional constraints among rhyolites, basalts, and metamorphic xenoliths from the Harney Basin, Oregon: International Journal of Earth Science, v. 91, p. 583-593.

Streck, M.J., and Grunder, A.L., 2008, Phenocryst-poor rhyolites of bimodal, tholeiitic provinces: the Rattlesnake Tuff and implications for mush extraction models: Bulletin of Volcanology, v. 70, p. 385-401.

Sun, S.-s., and McDonough, W.F., 1989, Chemical and isotopic systematics of oceanic basalts: implications for mantle composition and processes: Geological Society, London, Special Publications, v. 42, p. 313-345.

Tolan, T.L., Martin, B.S., Reidel, S.P., Anderson, J.L., Lindsey, K.A., and Burt, W., 2009, An introduction to the stratigraphy, structural geology, and hydrogeology of the Columbia River Flood-Basalt Province: A primer for the GSA Columbia River Basalt Group field trips, in O'Connor, J.E., Dorsey, R.J., and Madin, I.P., eds., Volcanoes to Vineyards: Geologic Field Trips through the Dynamic Landscape of the Pacific Northwest, Geological Society of America Field Guide, v. 15 , p. 599-643.

Tumpane, K.P., 2010, Age and isotopic investigations of the Olds Ferry terrane and its relations to other terranes of the Blue Mountains province, eastern Oregon and west-central Idaho [M.S. thesis]: Boise, Boise State University, 201 p.

Watts, K.E., Bindeman, I.N., and Schmitt, A.K., 2011, Large-volume rhyolite genesis in caldera complexes of the Snake River Plain: insights from the Kilgore Tuff of the Heise Volcanic Field, Idaho, with comparison to Yellowstone and BruneauJarbidge rhyolites: Journal of Petrology, v. 52, p. 857-890. 
Whalen, J.B., Currie, K.L., and Chappell, B.W., 1987, A-type granites: Geochemical characteristics, discrimination, and petrogenesis: Contributions to Mineralogy and Petrology, v. 95, p. 407-419.

Wolff, J.A., and Ramos, F.C., 2013, Source materials for the main phase of the Columbia River Basalt Group: Geochemical evidence and implications for magma storage and transport, in Reidel, S.P., Camp, V.E., Ross, M.E., Wolff, J.A., Martin, B.S., Tolan, T.L., and Wells, R.E., eds., The Columbia River Flood Basalt Province, Geological Society of America Special Paper, v. 497, p. 273-291.

Wolff, J.A., Ramos, F.C., Hart, G.L., Patterson, J.D., and Brandon, A.D., 2008, Columbia River flood basalts from a centralized crustal magmatic system: Nature Geoscience, v. 1, p. 177-180. 


\section{APPENDIX A: SAMPLES}

\section{Sample Nomenclature}

Rhyolite and tuff samples with prefix "EJ" were collected during a one-week

fieldwork period in September 2012. Samples with prefix "MS", “AS", "TF", "AL", and “CR” were collected from various field areas by Martin Streck, Arron Steiner, Phil Marcy, Adam Large, and Chris Ricker, respectively.

\section{Optical Microscopy}

$40-\mu \mathrm{m}$ thin sections were prepared on standard rectangular slides to determine the petrography of the samples and investigate mineral textures using a Leica optical microscope (Table 7). 


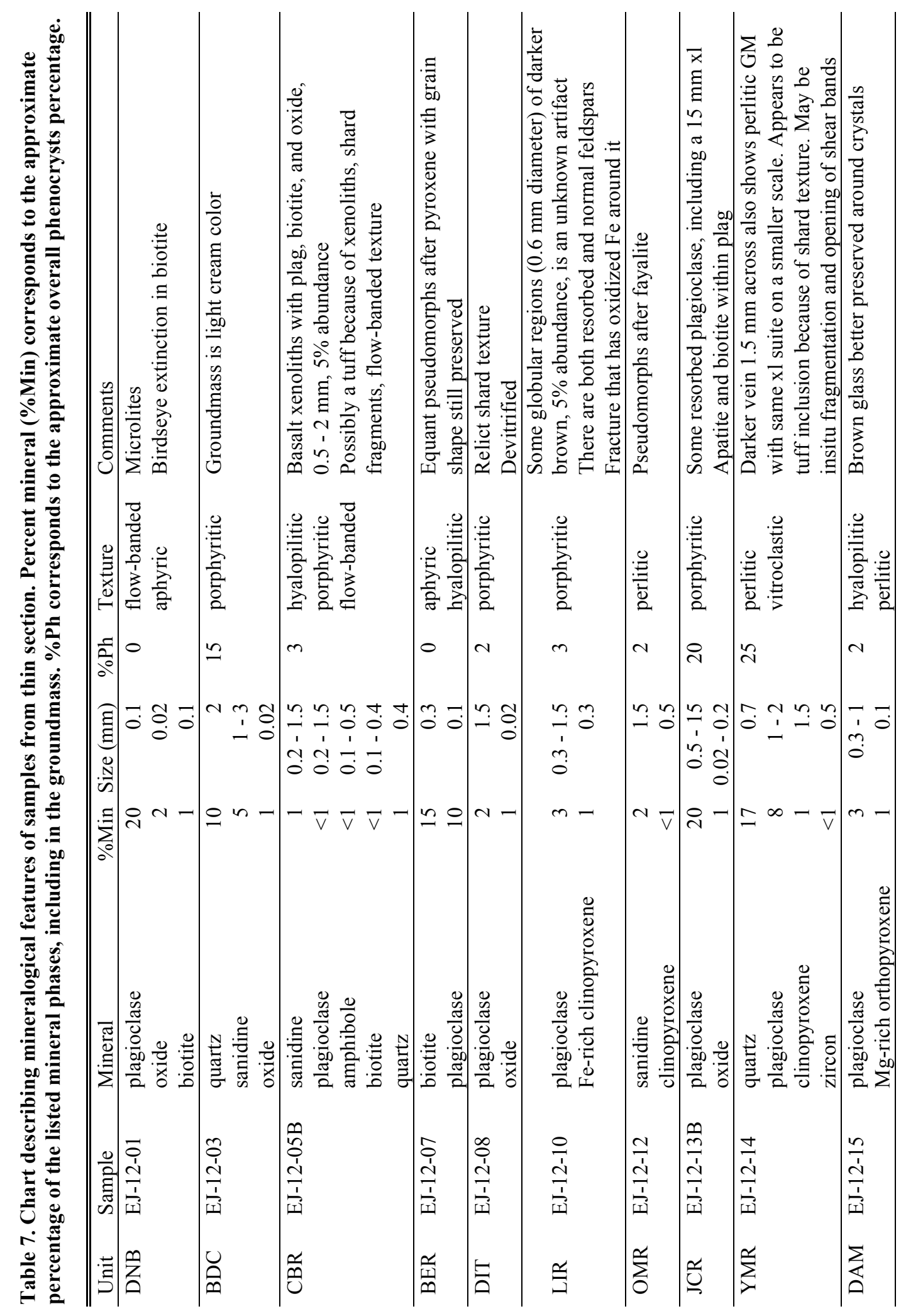




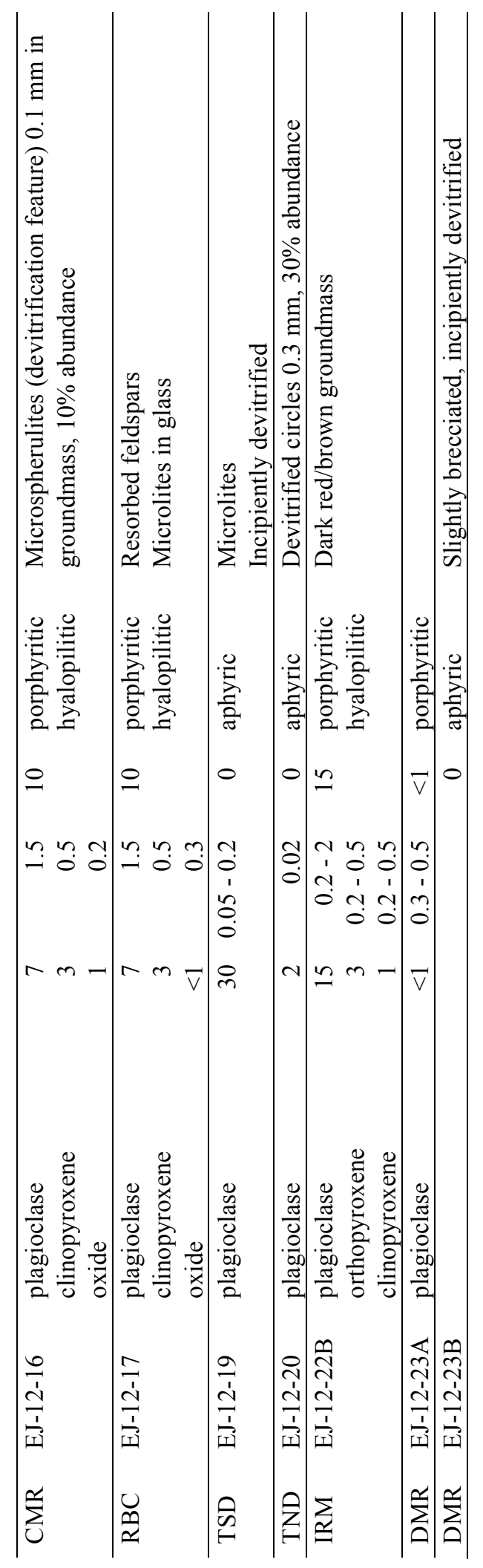




\section{APPENDIX B: XRF AND ICP-MS CHEMICAL DATA}

\section{Methods}

\section{X-Ray Fluorescence}

Bulk analyses of the rock samples were conducted at the GeoAnalytical Lab at Washington State University (WSU) to determine major and trace element abundances. Fresh portions of the samples were crushed into fine gravel-sized fragments using a Chipmunk Rock Crusher. The samples were ground into a powder using a tungsten carbide bowl in a swing mill. The powders were homogeneously mixed with dilithium tetraborate $\left(\mathrm{Li}_{2} \mathrm{~B}_{4} \mathrm{O}_{7}\right)$ at a 2:1 flux to rock ratio in a VSM3 vortex mixer. Following the sample preparation and analytical procedures of Johnson et al. (1999), the mixture was then placed in graphite crucibles, fused into glass beads in a muffle furnace at $1000^{\circ} \mathrm{C}$, reground with the swing mill, and fused again prior to analysis to ensure complete homogenization. One duplicate bead was prepared for each set of nineteen unknown samples to verify reproducibility of the analysis. A ThermoARL AdvantXP+ sequential X-ray fluorescence (XRF) spectrometer was used to analyze for ten major elements, $\mathrm{Si}$, Ti, Al, Fe, Mn, Mg, Ca, Na, K, and P, and twenty-one trace elements, Ni, Cr, Sc, V, Ba, Rb, Sr, Zr, Y, Nb, Ga, Cu, Zn, Pb, La, Ce, Th, Nd, U, Cs, and As. The X-ray intensity of each element of the prepared unknown glass bead was compared versus beads prepared from known standards to determine the unknown concentrations.

\section{Inductively Coupled Plasma Mass Spectrometry}

An HP4500 inductively coupled plasma mass spectrometer (ICP-MS) was used for further trace element analyses at the GeoAnalytical Lab at WSU. Analyses were 
conducted using a 1:1 dilithium tetraborate to rock ratio. The trace elements analyzed were $\mathrm{Ba}, \mathrm{Rb}, \mathrm{Y}, \mathrm{Nb}, \mathrm{Cs}, \mathrm{Hf}, \mathrm{Ta}, \mathrm{Pb}, \mathrm{Th}, \mathrm{U}, \mathrm{Sr}, \mathrm{Zr}$, and the fourteen naturally occurring rare earth elements (REE), La, Ce, Pr, Nd, Sm, Eu, Gd, Tb, Dy, Ho, Er, Tm, Yb, and Lu. The sample preparation and analytical procedures are after Knaack and Hooper (1994).

\section{Major and Trace Elements}

The data for both major and trace elements are shown in Table 8. All samples that were analyzed for Sr isotopes are included in this table with the exception of AL-13$015 b$. 
Table 8. Major and trace element data from XRF and ICP-MS.

\begin{tabular}{|c|c|c|c|c|c|c|}
\hline $\begin{array}{l}\text { Unit } \\
\text { Sample } \\
\end{array}$ & $\begin{array}{c}\text { DNB } \\
\text { EJ-12-01 } \\
\end{array}$ & $\begin{array}{c}\text { BDC } \\
\text { EJ-12-03 }\end{array}$ & $\begin{array}{c}\text { CBR } \\
\text { EJ-12-05B }\end{array}$ & $\begin{array}{c}\text { SCR } \\
\text { EJ-12-06A } \\
\end{array}$ & $\begin{array}{c}\text { BER } \\
\text { EJ-12-07 } \\
\end{array}$ & $\begin{array}{c}\text { DIT } \\
\text { EJ-12-08 } \\
\end{array}$ \\
\hline \multicolumn{7}{|c|}{ XRF analyses, normalized $100 \%$ volatile free, weight $\%$} \\
\hline $\mathrm{SiO}_{2}$ & 76.14 & 78.81 & 75.34 & 75.44 & 71.71 & 77.92 \\
\hline $\mathrm{TiO}_{2}$ & 0.064 & 0.089 & 0.198 & 0.062 & 0.400 & 0.159 \\
\hline $\mathbf{A l}_{2} \mathbf{O}_{3}$ & 14.23 & 11.22 & 13.08 & 13.75 & 13.26 & 11.42 \\
\hline $\mathrm{FeO}^{*}$ & 0.66 & 0.80 & 1.40 & 0.98 & 4.51 & 1.66 \\
\hline MnO & 0.072 & 0.019 & 0.049 & 0.087 & 0.058 & 0.015 \\
\hline MgO & 0.08 & 0.00 & 0.23 & 0.14 & 1.23 & 0.23 \\
\hline $\mathrm{CaO}$ & 1.19 & 0.05 & 1.15 & 1.19 & 2.93 & 0.59 \\
\hline $\mathrm{Na}_{2} \mathrm{O}$ & 3.64 & 2.36 & 2.80 & 3.92 & 3.17 & 4.39 \\
\hline $\mathbf{K}_{2} \mathbf{O}$ & 3.89 & 6.65 & 5.65 & 4.41 & 2.60 & 3.58 \\
\hline $\mathbf{P}_{2} \mathbf{O}_{5}$ & 0.019 & 0.009 & 0.099 & 0.022 & 0.123 & 0.035 \\
\hline \multicolumn{7}{|c|}{ XRF analyses, unnormalized ppm } \\
\hline $\mathbf{N i}$ & 0.6 & 1.6 & 2.3 & 1.6 & 48.6 & 1.9 \\
\hline $\mathrm{Cr}$ & 3.7 & 4.1 & 5.4 & 3.3 & 73.7 & 3.2 \\
\hline Sc & 3.1 & 4.1 & 3.4 & 3.2 & 11.5 & 4.6 \\
\hline $\mathbf{V}$ & 4.1 & 5.5 & 14.2 & 6.3 & 50.9 & 12.4 \\
\hline $\mathbf{B a}$ & 1120.3 & 148.9 & 499.6 & 871.5 & 1170.4 & 1327.7 \\
\hline $\mathbf{R b}$ & 73.7 & 173.7 & 167.9 & 98.4 & 52.2 & 68.4 \\
\hline $\mathrm{Sr}$ & 110.8 & 6.1 & 103.6 & 129.3 & 156.2 & 39.7 \\
\hline $\mathrm{Zr}$ & 52.5 & 271.6 & 116.5 & 78.4 & 85.8 & 390.6 \\
\hline $\mathbf{Y}$ & 20.9 & 36.3 & 23.0 & 27.7 & 38.5 & 68.6 \\
\hline Nb & 11.8 & 16.1 & 13.5 & 12.6 & 9.5 & 22.2 \\
\hline Ga & 15.8 & 15.4 & 14.7 & 15.0 & 15.1 & 19.7 \\
\hline $\mathrm{Cu}$ & 1.3 & 6.4 & 3.6 & 6.8 & 45.6 & 4.7 \\
\hline $\mathbf{Z n}$ & 27.2 & 68.8 & 30.4 & 42.6 & 57.3 & 121.4 \\
\hline $\mathbf{P b}$ & 16.7 & 45.6 & 23.0 & 20.8 & 11.1 & 10.4 \\
\hline $\mathbf{L a}$ & 20.7 & 33.7 & 24.8 & 15.9 & 21.8 & 38.7 \\
\hline $\mathrm{Ce}$ & 30.8 & 48.9 & 47.6 & 27.3 & 41.7 & 85.3 \\
\hline Th & 6.6 & 16.2 & 16.9 & 4.4 & 4.3 & 7.7 \\
\hline Nd & 15.1 & 33.3 & 17.3 & 13.4 & 22.6 & 40.6 \\
\hline $\mathbf{U}$ & 2.3 & 3.4 & 8.1 & 2.9 & 1.8 & 3.2 \\
\hline
\end{tabular}


Table 8 continued. Major and trace element data from XRF and ICP-MS.

\begin{tabular}{|c|c|c|c|c|c|c|}
\hline $\begin{array}{l}\text { Unit } \\
\text { Sample } \\
\end{array}$ & $\begin{array}{c}\text { DNB } \\
\text { EJ-12-01 } \\
\end{array}$ & $\begin{array}{c}\text { BDC } \\
\text { EJ-12-03 }\end{array}$ & $\begin{array}{c}\text { CBR } \\
\text { EJ-12-05B }\end{array}$ & $\begin{array}{c}\text { SCR } \\
\text { EJ-12-06A } \\
\end{array}$ & $\begin{array}{c}\text { BER } \\
\text { EJ-12-07 }\end{array}$ & $\begin{array}{c}\text { DIT } \\
\text { EJ-12-08 } \\
\end{array}$ \\
\hline \multicolumn{7}{|c|}{ ICP-MS analyses, ppm } \\
\hline La & 21.04 & 32.04 & 25.23 & 16.37 & 22.12 & 37.70 \\
\hline $\mathrm{Ce}$ & 31.48 & 47.37 & 46.83 & 31.37 & 40.83 & 90.30 \\
\hline Pr & 4.43 & 8.93 & 5.28 & 3.80 & 5.46 & 10.47 \\
\hline Nd & 15.41 & 33.59 & 18.51 & 14.52 & 21.89 & 41.23 \\
\hline Sm & 3.44 & 7.32 & 3.83 & 3.83 & 5.25 & 9.81 \\
\hline Eu & 0.73 & 0.43 & 0.55 & 0.58 & 1.14 & 1.59 \\
\hline Gd & 3.07 & 6.03 & 3.36 & 3.83 & 5.51 & 9.60 \\
\hline $\mathbf{T b}$ & 0.55 & 1.11 & 0.58 & 0.71 & 0.97 & 1.83 \\
\hline Dy & 3.33 & 7.14 & 3.72 & 4.50 & 6.21 & 12.13 \\
\hline Но & 0.66 & 1.51 & 0.77 & 0.91 & 1.35 & 2.64 \\
\hline $\mathbf{E r}$ & 1.83 & 4.39 & 2.23 & 2.55 & 3.76 & 7.74 \\
\hline $\mathbf{T m}$ & 0.28 & 0.68 & 0.35 & 0.39 & 0.58 & 1.23 \\
\hline $\mathbf{Y b}$ & 1.80 & 4.62 & 2.38 & 2.59 & 3.69 & 8.15 \\
\hline Lu & 0.28 & 0.72 & 0.39 & 0.41 & 0.59 & 1.29 \\
\hline $\mathbf{B a}$ & 1151.42 & 152.84 & 510.72 & 894.79 & 1174.20 & 1358.46 \\
\hline Th & 6.94 & 13.00 & 16.89 & 4.80 & 3.85 & 7.36 \\
\hline Nb & 8.86 & 9.28 & 12.96 & 11.07 & 8.46 & 20.61 \\
\hline $\mathbf{Y}$ & 18.72 & 34.19 & 21.35 & 25.69 & 37.05 & 65.58 \\
\hline Hf & 2.42 & 8.87 & 3.88 & 3.31 & 2.92 & 10.59 \\
\hline Ta & 0.80 & 0.47 & 1.67 & 0.84 & 0.62 & 1.33 \\
\hline $\mathbf{U}$ & 2.66 & 4.41 & 7.87 & 2.54 & 1.43 & 3.28 \\
\hline $\mathbf{P b}$ & 15.18 & 43.86 & 21.65 & 19.49 & 10.36 & 10.39 \\
\hline $\mathbf{R b}$ & 75.4 & 178.5 & 168.7 & 98.8 & 51.0 & 69.4 \\
\hline Cs & 2.02 & 2.77 & 8.11 & 3.02 & 1.76 & 1.71 \\
\hline $\mathrm{Sr}$ & 117 & 8 & 108 & 133 & 159 & 44 \\
\hline Sc & 2.88 & 2.62 & 3.21 & 3.52 & 12.08 & 3.41 \\
\hline $\mathrm{Zr}$ & 55 & 282 & 119 & 81 & 85 & 396 \\
\hline
\end{tabular}


Table 8 continued, Major and trace element data from XRF and ICP-MS.

\begin{tabular}{|c|c|c|c|c|c|c|}
\hline $\begin{array}{l}\text { Unit } \\
\text { Sample }\end{array}$ & $\begin{array}{c}\text { LIR } \\
\text { EJ-12-10 }\end{array}$ & $\begin{array}{c}\text { OMR } \\
\text { EJ-12-12 }\end{array}$ & $\begin{array}{c}\text { JCR } \\
\text { EJ-12-13B } \\
\end{array}$ & $\begin{array}{c}\text { YMR } \\
\text { EJ-12-14 }\end{array}$ & $\begin{array}{c}\text { DAM } \\
\text { EJ-12-15 }\end{array}$ & $\begin{array}{c}\text { CMR } \\
\text { EJ-12-16 }\end{array}$ \\
\hline \multicolumn{7}{|c|}{ XRF analyses, normalized $100 \%$ volatile free, weight $\%$} \\
\hline $\mathrm{SiO}_{2}$ & 71.08 & 74.19 & 73.52 & 77.14 & 72.78 & 73.04 \\
\hline $\mathrm{TiO}_{2}$ & 0.434 & 0.312 & 0.511 & 0.153 & 0.257 & 0.717 \\
\hline $\mathbf{A l}_{2} \mathbf{O}_{3}$ & 12.44 & 12.92 & 13.99 & 12.17 & 14.44 & 12.74 \\
\hline $\mathrm{FeO}^{*}$ & 5.79 & 3.15 & 1.81 & 1.40 & 1.86 & 3.51 \\
\hline MnO & 0.138 & 0.071 & 0.021 & 0.038 & 0.054 & 0.078 \\
\hline MgO & 0.23 & 0.51 & 0.03 & 0.14 & 0.57 & 0.34 \\
\hline $\mathrm{CaO}$ & 1.62 & 1.05 & 1.46 & 0.49 & 2.05 & 1.64 \\
\hline $\mathrm{Na}_{2} \mathrm{O}$ & 4.16 & 4.41 & 4.11 & 3.70 & 3.23 & 2.81 \\
\hline $\mathbf{K}_{2} \mathbf{O}$ & 4.04 & 3.38 & 4.38 & 4.74 & 4.68 & 4.99 \\
\hline $\mathbf{P}_{2} \mathbf{O}_{5}$ & 0.059 & 0.015 & 0.154 & 0.019 & 0.076 & 0.145 \\
\hline \multicolumn{7}{|c|}{ XRF analyses, unnormalized ppm } \\
\hline $\mathbf{N i}$ & 4.6 & 2.5 & 4.0 & 2.6 & 5.6 & 3.9 \\
\hline $\mathbf{C r}$ & 2.9 & 2.0 & 2.8 & 1.7 & 5.3 & 3.2 \\
\hline Sc & 7.5 & 0.6 & 7.8 & 1.3 & 5.6 & 11.8 \\
\hline $\mathbf{V}$ & 3.4 & 1.0 & 12.3 & 4.0 & 23.1 & 12.4 \\
\hline $\mathbf{B a}$ & 1654.0 & 1438.5 & 2000.1 & 247.1 & 1520.3 & 1369.3 \\
\hline $\mathbf{R b}$ & 111.1 & 160.7 & 82.7 & 140.4 & 87.4 & 147.2 \\
\hline $\mathrm{Sr}$ & 143.2 & 33.9 & 274.2 & 20.4 & 244.9 & 178.8 \\
\hline $\mathbf{Z r}$ & 534.3 & 726.7 & 575.2 & 296.8 & 155.7 & 295.1 \\
\hline $\mathbf{Y}$ & 87.0 & 100.0 & 51.6 & 88.0 & 17.1 & 41.9 \\
\hline Nb & 36.3 & 44.9 & 44.1 & 36.8 & 9.4 & 19.2 \\
\hline Ga & 25.5 & 25.9 & 22.0 & 23.3 & 14.2 & 18.1 \\
\hline $\mathrm{Cu}$ & 7.5 & 2.6 & 0.7 & 4.5 & 9.0 & 2.6 \\
\hline $\mathbf{Z n}$ & 172.6 & 180.9 & 102.6 & 105.3 & 35.2 & 91.0 \\
\hline $\mathbf{P b}$ & 20.5 & 24.8 & 25.3 & 20.8 & 15.9 & 23.9 \\
\hline La & 64.3 & 66.1 & 82.5 & 65.3 & 21.1 & 47.5 \\
\hline $\mathrm{Ce}$ & 125.5 & 147.0 & 164.7 & 125.5 & 41.3 & 88.8 \\
\hline Th & 13.4 & 15.4 & 9.0 & 13.5 & 6.8 & 17.0 \\
\hline Nd & 65.1 & 75.1 & 73.2 & 56.7 & 15.7 & 39.4 \\
\hline $\mathbf{U}$ & 4.1 & 4.0 & 1.5 & 4.5 & 1.5 & 5.7 \\
\hline
\end{tabular}


Table 8 continued. Major and trace element data from XRF and ICP-MS.

\begin{tabular}{|c|c|c|c|c|c|c|}
\hline $\begin{array}{l}\text { Unit } \\
\text { Sample } \\
\end{array}$ & $\begin{array}{c}\text { LIR } \\
\text { EJ-12-10 }\end{array}$ & $\begin{array}{c}\text { OMR } \\
\text { EJ-12-12 } \\
\end{array}$ & $\begin{array}{c}\text { JCR } \\
\text { EJ-12-13B } \\
\end{array}$ & $\begin{array}{c}\text { YMR } \\
\text { EJ-12-14 }\end{array}$ & $\begin{array}{c}\text { DAM } \\
\text { EJ-12-15 } \\
\end{array}$ & $\begin{array}{c}\text { CMR } \\
\text { EJ-12-16 }\end{array}$ \\
\hline \multicolumn{7}{|c|}{ ICP-MS analyses, ppm } \\
\hline $\mathbf{L a}$ & 62.25 & 71.54 & 86.46 & 64.49 & 24.06 & 45.99 \\
\hline $\mathrm{Ce}$ & 128.56 & 149.47 & 168.36 & 129.69 & 42.55 & 89.79 \\
\hline Pr & 16.26 & 18.80 & 20.01 & 15.60 & 4.73 & 10.66 \\
\hline Nd & 65.29 & 75.14 & 74.07 & 58.58 & 16.60 & 40.45 \\
\hline Sm & 15.20 & 17.35 & 14.14 & 13.01 & 3.16 & 8.52 \\
\hline Eu & 3.74 & 3.04 & 2.80 & 0.50 & 0.67 & 1.70 \\
\hline Gd & 14.97 & 17.18 & 11.33 & 12.73 & 2.74 & 7.71 \\
\hline Tb & 2.62 & 2.99 & 1.77 & 2.35 & 0.44 & 1.27 \\
\hline Dy & 16.50 & 18.79 & 10.16 & 15.16 & 2.71 & 7.65 \\
\hline Ho & 3.41 & 3.91 & 1.96 & 3.23 & 0.56 & 1.53 \\
\hline Er & 9.52 & 10.92 & 5.16 & 9.30 & 1.64 & 4.11 \\
\hline $\mathbf{T m}$ & 1.40 & 1.63 & 0.74 & 1.41 & 0.25 & 0.60 \\
\hline $\mathbf{Y b}$ & 8.81 & 10.50 & 4.62 & 9.02 & 1.70 & 3.81 \\
\hline Lu & 1.41 & 1.65 & 0.69 & 1.41 & 0.28 & 0.58 \\
\hline $\mathbf{B a}$ & 1662.12 & 1456.96 & 2111.15 & 251.34 & 1550.00 & 1380.32 \\
\hline Th & 13.50 & 15.48 & 9.52 & 13.43 & 6.94 & 16.66 \\
\hline $\mathbf{N b}$ & 34.44 & 43.94 & 42.76 & 36.44 & 8.19 & 18.07 \\
\hline $\mathbf{Y}$ & 86.13 & 97.97 & 49.26 & 85.74 & 15.83 & 39.77 \\
\hline Hf & 14.06 & 18.10 & 13.60 & 9.62 & 4.23 & 8.00 \\
\hline Ta & 2.16 & 2.62 & 2.40 & 2.30 & 0.70 & 1.36 \\
\hline $\mathbf{U}$ & 3.87 & 4.34 & 2.99 & 4.08 & 2.67 & 5.45 \\
\hline $\mathbf{P b}$ & 19.12 & 22.98 & 23.76 & 19.65 & 14.21 & 24.29 \\
\hline $\mathbf{R b}$ & 109.3 & 160.0 & 83.7 & 142.6 & 87.2 & 145.8 \\
\hline Cs & 1.89 & 9.41 & 0.94 & 3.48 & 3.27 & 5.18 \\
\hline $\mathrm{Sr}$ & 147 & 37 & 285 & 24 & 256 & 185 \\
\hline Sc & 8.08 & 0.86 & 7.03 & 1.42 & 4.34 & 11.92 \\
\hline $\mathbf{Z r}$ & 542 & 744 & 578 & 296 & 158 & 298 \\
\hline
\end{tabular}


Table 8 continued. Major and trace element data from XRF and ICP-MS.

\begin{tabular}{|c|c|c|c|c|c|c|}
\hline $\begin{array}{l}\text { Unit } \\
\text { Sample } \\
\end{array}$ & $\begin{array}{c}\text { RBC } \\
\text { EJ-12-17 }\end{array}$ & $\begin{array}{c}\text { TSD } \\
\text { EJ-12-19 }\end{array}$ & $\begin{array}{c}\text { TND } \\
\text { EJ-12-20 }\end{array}$ & $\begin{array}{c}\text { IRM } \\
\text { EJ-12-22B }\end{array}$ & $\begin{array}{c}\text { DMR } \\
\text { EJ-12-23A }\end{array}$ & $\begin{array}{c}\text { DMR } \\
\text { EJ-12-23B }\end{array}$ \\
\hline \multicolumn{7}{|c|}{ XRF analyses, normalized $100 \%$ volatile free, weight $\%$} \\
\hline $\mathrm{SiO}_{2}$ & 72.40 & 77.06 & 76.83 & 64.65 & 76.72 & 76.90 \\
\hline $\mathrm{TiO}_{2}$ & 0.704 & 0.056 & 0.059 & 0.639 & 0.118 & 0.051 \\
\hline $\mathbf{A l}_{2} \mathbf{O}_{3}$ & 12.65 & 12.97 & 13.08 & 16.70 & 13.03 & 13.34 \\
\hline $\mathrm{FeO}^{*}$ & 3.92 & 0.55 & 0.60 & 4.17 & 1.38 & 1.17 \\
\hline MnO & 0.089 & 0.068 & 0.072 & 0.069 & 0.033 & 0.044 \\
\hline MgO & 0.40 & 0.21 & 0.08 & 2.38 & 0.03 & 0.03 \\
\hline $\mathrm{CaO}$ & 1.74 & 0.87 & 0.77 & 5.45 & 1.05 & 0.69 \\
\hline $\mathrm{Na}_{2} \mathrm{O}$ & 2.59 & 2.75 & 3.14 & 3.07 & 3.12 & 2.90 \\
\hline $\mathbf{K}_{2} \mathbf{O}$ & 5.37 & 5.45 & 5.34 & 2.68 & 4.50 & 4.86 \\
\hline $\mathbf{P}_{2} \mathbf{O}_{5}$ & 0.145 & 0.023 & 0.025 & 0.194 & 0.013 & 0.015 \\
\hline \multicolumn{7}{|c|}{ XRF analyses, unnormalized ppm } \\
\hline $\mathbf{N i}$ & 3.4 & 3.6 & 4.0 & 22.1 & 0.1 & 0.0 \\
\hline $\mathbf{C r}$ & 1.1 & 3.7 & 2.7 & 46.7 & 3.5 & 3.0 \\
\hline Sc & 12.4 & 3.4 & 2.8 & 11.2 & 3.3 & 3.3 \\
\hline $\mathbf{V}$ & 14.1 & 2.2 & 1.9 & 91.8 & 4.7 & 0.7 \\
\hline $\mathbf{B a}$ & 1286.8 & 195.4 & 86.0 & 870.5 & 1597.1 & 579.8 \\
\hline $\mathbf{R b}$ & 151.3 & 107.9 & 106.6 & 36.0 & 92.8 & 122.3 \\
\hline $\mathrm{Sr}$ & 168.6 & 26.7 & 18.4 & 469.5 & 90.6 & 33.2 \\
\hline $\mathbf{Z r}$ & 293.3 & 58.5 & 62.9 & 131.8 & 170.1 & 72.9 \\
\hline $\mathbf{Y}$ & 41.4 & 34.2 & 34.5 & 14.6 & 37.0 & 35.2 \\
\hline $\mathbf{N b}$ & 19.9 & 21.2 & 21.7 & 5.6 & 10.0 & 10.7 \\
\hline Ga & 17.5 & 14.3 & 14.9 & 18.4 & 16.9 & 16.3 \\
\hline $\mathrm{Cu}$ & 3.5 & 3.5 & 1.3 & 20.1 & 1.1 & 0.2 \\
\hline $\mathbf{Z n}$ & 87.4 & 23.3 & 25.4 & 68.1 & 60.8 & 39.6 \\
\hline $\mathbf{P b}$ & 24.5 & 22.6 & 21.8 & 9.1 & 14.2 & 16.6 \\
\hline $\mathbf{L a}$ & 45.6 & 8.5 & 15.4 & 18.5 & 32.8 & 21.3 \\
\hline $\mathrm{Ce}$ & 93.4 & 21.4 & 32.0 & 35.6 & 61.8 & 43.9 \\
\hline Th & 17.2 & 7.4 & 9.1 & 3.9 & 7.8 & 9.9 \\
\hline Nd & 41.0 & 11.9 & 13.4 & 14.8 & 27.9 & 19.0 \\
\hline $\mathbf{U}$ & 3.9 & 3.4 & 3.2 & 1.5 & 1.5 & 3.5 \\
\hline
\end{tabular}


Table 8 continued. Major and trace element data from XRF and ICP-MS.

\begin{tabular}{|c|c|c|c|c|c|c|}
\hline $\begin{array}{l}\text { Unit } \\
\text { Sample } \\
\end{array}$ & $\begin{array}{c}\text { RBC } \\
\text { EJ-12-17 }\end{array}$ & $\begin{array}{c}\text { TSD } \\
\text { EJ-12-19 }\end{array}$ & $\begin{array}{c}\text { TND } \\
\text { EJ-12-20 }\end{array}$ & $\begin{array}{c}\text { IRM } \\
\text { EJ-12-22B }\end{array}$ & $\begin{array}{c}\text { DMR } \\
\text { EJ-12-23A }\end{array}$ & $\begin{array}{c}\text { DMR } \\
\text { EJ-12-23B }\end{array}$ \\
\hline \multicolumn{7}{|c|}{ ICP-MS analyses, ppm } \\
\hline $\mathbf{L a}$ & 45.44 & 10.88 & 13.50 & 19.36 & 36.35 & 22.69 \\
\hline $\mathrm{Ce}$ & 89.22 & 22.05 & 26.90 & 36.66 & 69.29 & 44.39 \\
\hline Pr & 10.63 & 2.81 & 3.32 & 4.38 & 8.06 & 5.19 \\
\hline Nd & 40.70 & 11.11 & 12.60 & 16.42 & 29.18 & 18.85 \\
\hline Sm & 8.58 & 3.27 & 3.47 & 3.39 & 5.98 & 4.53 \\
\hline Eu & 1.71 & 0.32 & 0.29 & 0.99 & 0.79 & 0.23 \\
\hline Gd & 7.76 & 3.55 & 3.76 & 2.90 & 5.61 & 4.66 \\
\hline $\mathbf{T b}$ & 1.26 & 0.70 & 0.74 & 0.45 & 0.98 & 0.87 \\
\hline Dy & 7.70 & 4.79 & 5.03 & 2.58 & 6.14 & 5.69 \\
\hline Ho & 1.52 & 1.06 & 1.10 & 0.50 & 1.29 & 1.20 \\
\hline Er & 4.11 & 3.28 & 3.34 & 1.32 & 3.70 & 3.39 \\
\hline $\mathbf{T m}$ & 0.60 & 0.53 & 0.55 & 0.19 & 0.56 & 0.52 \\
\hline $\mathbf{Y b}$ & 3.77 & 3.71 & 3.83 & 1.18 & 3.61 & 3.36 \\
\hline Lu & 0.59 & 0.62 & 0.64 & 0.19 & 0.57 & 0.52 \\
\hline $\mathbf{B a}$ & 1302.90 & 200.24 & 88.07 & 879.70 & 1626.24 & 588.85 \\
\hline Th & 16.69 & 7.73 & 8.50 & 3.62 & 8.52 & 9.43 \\
\hline $\mathbf{N b}$ & 17.96 & 20.50 & 20.80 & 5.36 & 9.61 & 9.49 \\
\hline $\mathbf{Y}$ & 39.48 & 31.96 & 32.36 & 13.32 & 35.11 & 33.87 \\
\hline Hf & 8.00 & 3.09 & 3.28 & 3.27 & 5.14 & 3.19 \\
\hline Ta & 1.36 & 1.98 & 2.06 & 0.41 & 0.79 & 1.07 \\
\hline $\mathbf{U}$ & 5.32 & 3.32 & 3.48 & 1.40 & 3.11 & 4.00 \\
\hline $\mathbf{P b}$ & 24.14 & 20.75 & 21.40 & 8.20 & 14.88 & 16.07 \\
\hline $\mathbf{R b}$ & 150.0 & 108.8 & 108.3 & 35.6 & 93.2 & 122.5 \\
\hline Cs & 5.26 & 3.84 & 3.52 & 1.14 & 3.87 & 6.01 \\
\hline $\mathrm{Sr}$ & 172 & 31 & 21 & 474 & 96 & 37 \\
\hline Sc & 11.82 & 2.84 & 2.97 & 11.22 & 3.41 & 3.14 \\
\hline $\mathbf{Z r}$ & 294 & 60 & 66 & 128 & 172 & 75 \\
\hline
\end{tabular}


Table 8 continued. Major and trace element data from XRF and ICP-MS.

\begin{tabular}{|c|c|c|c|c|c|c|}
\hline $\begin{array}{l}\text { Unit } \\
\text { Sample } \\
\end{array}$ & $\begin{array}{c}\text { UNI } \\
\text { CR-U3A } \\
\end{array}$ & $\begin{array}{c}\text { UNI } \\
\text { CR-U4B }\end{array}$ & $\begin{array}{c}\text { UNI } \\
\text { MS-12-14b } \\
\end{array}$ & $\begin{array}{c}\text { DIT } \\
\text { CR-U35a }\end{array}$ & $\begin{array}{c}\text { DIT } \\
\text { MS-PCIT 1A } \\
\end{array}$ & $\begin{array}{c}\text { DIT } \\
\text { MS-12-29.1 } \\
\end{array}$ \\
\hline \multicolumn{7}{|c|}{ XRF analyses, normalized $100 \%$ volatile free, weight $\%$} \\
\hline $\mathrm{SiO}_{2}$ & 76.10 & 72.07 & 75.89 & 74.11 & 73.82 & 76.30 \\
\hline $\mathrm{TiO}_{2}$ & 0.09 & 0.27 & 0.212 & 0.256 & 0.32 & 0.173 \\
\hline $\mathrm{Al}_{2} \mathrm{O}_{3}$ & 13.34 & 15.30 & 13.83 & 13.15 & 13.58 & 12.30 \\
\hline $\mathrm{FeO}^{*}$ & 1.19 & 1.68 & 0.96 & 2.61 & 2.91 & 2.04 \\
\hline MnO & 0.02 & 0.05 & 0.017 & 0.064 & 0.03 & 0.054 \\
\hline MgO & 0.06 & 0.48 & 0.10 & 0.09 & 0.31 & 0.04 \\
\hline $\mathrm{CaO}$ & 0.72 & 2.12 & 1.26 & 0.48 & 1.04 & 0.58 \\
\hline $\mathrm{Na}_{2} \mathrm{O}$ & 3.25 & 4.10 & 3.90 & 3.16 & 2.29 & 3.78 \\
\hline $\mathrm{K}_{2} \mathrm{O}$ & 5.22 & 3.84 & 3.77 & 6.06 & 5.64 & 4.73 \\
\hline $\mathbf{P}_{2} \mathbf{O}_{5}$ & 0.01 & 0.08 & 0.049 & 0.021 & 0.06 & 0.014 \\
\hline \multicolumn{7}{|c|}{ XRF analyses, unnormalized ppm } \\
\hline $\mathbf{N i}$ & 0.0 & 0.0 & 3.7 & 4.0 & 3.8 & 2.4 \\
\hline $\mathrm{Cr}$ & 1.3 & 5.3 & 3.8 & 3.4 & 4.0 & 3.4 \\
\hline Sc & 3.0 & 3.8 & 3.4 & 1.7 & 5.1 & 4.1 \\
\hline $\mathbf{V}$ & 0.3 & 21.3 & 8.5 & 6.3 & 10.0 & 3.1 \\
\hline $\mathbf{B a}$ & 1102.1 & 794.4 & 1191.3 & 1815.4 & 1382.4 & 1411.0 \\
\hline $\mathbf{R b}$ & 106.6 & 82.3 & 80.3 & 84.6 & 79.1 & 74.2 \\
\hline $\mathrm{Sr}$ & 63.8 & 263.3 & 173.4 & 54.4 & 104.2 & 27.6 \\
\hline $\mathbf{Z r}$ & 125.4 & 118.0 & 165.8 & 390.2 & 384.3 & 428.8 \\
\hline $\mathbf{Y}$ & 26.8 & 16.3 & 25.4 & 62.1 & 76.5 & 93.0 \\
\hline $\mathbf{N b}$ & 17.2 & 12.3 & 14.7 & 24.3 & 20.1 & 24.2 \\
\hline $\mathbf{G a}$ & 16.9 & 15.8 & 17.0 & 22.0 & 21.5 & 21.5 \\
\hline $\mathrm{Cu}$ & 1.2 & 0.5 & 5.0 & 2.9 & 5.2 & 1.4 \\
\hline $\mathrm{Zn}$ & 50.5 & 39.2 & 26.1 & 149.1 & 84.5 & 152.4 \\
\hline $\mathbf{P b}$ & 15.2 & 13.2 & 14.8 & 15.1 & 14.6 & 18.7 \\
\hline $\mathbf{L a}$ & 31.2 & 25.4 & 36.6 & 44.6 & 47.6 & 47.4 \\
\hline $\mathrm{Ce}$ & 59.1 & 44.7 & 69.6 & 82.8 & 94.1 & 91.9 \\
\hline Th & 13.0 & 9.7 & 9.8 & 6.6 & 8.4 & 7.6 \\
\hline Nd & 27.2 & 17.4 & 26.1 & 43.7 & 46.5 & 49.5 \\
\hline $\mathbf{U}$ & 3.8 & 4.9 & 3.3 & 1.8 & 3.1 & 4.7 \\
\hline
\end{tabular}


Table 8 continued. Major and trace element data from XRF and ICP-MS.

\begin{tabular}{|c|c|c|c|c|c|c|}
\hline $\begin{array}{l}\text { Unit } \\
\text { Sample } \\
\end{array}$ & $\begin{array}{c}\text { UNI } \\
\text { CR-U3A }\end{array}$ & $\begin{array}{c}\text { UNI } \\
\text { CR-U4B }\end{array}$ & $\begin{array}{c}\text { UNI } \\
\text { MS-12-14b } \\
\end{array}$ & $\begin{array}{c}\text { DIT } \\
\text { CR-U35a } \\
\end{array}$ & $\begin{array}{c}\text { DIT } \\
\text { MS-PCIT 1A } \\
\end{array}$ & $\begin{array}{c}\text { DIT } \\
\text { MS-12-29.1 } \\
\end{array}$ \\
\hline \multicolumn{7}{|c|}{ ICP-MS analyses, ppm } \\
\hline La & 34.51 & 26.22 & 40.29 & 46.34 & 46.79 & 46.68 \\
\hline $\mathrm{Ce}$ & 63.11 & 47.11 & 70.95 & 92.01 & 94.93 & 93.30 \\
\hline Pr & 7.39 & 5.24 & 7.78 & 11.73 & 12.29 & 12.42 \\
\hline Nd & 26.00 & 18.00 & 26.38 & 46.24 & 49.40 & 49.54 \\
\hline Sm & 5.23 & 3.33 & 4.59 & 10.28 & 11.48 & 11.60 \\
\hline $\mathbf{E u}$ & 0.76 & 0.79 & 0.92 & 1.91 & 2.24 & 1.71 \\
\hline Gd & 4.57 & 2.81 & 3.95 & 9.91 & 11.93 & 12.25 \\
\hline $\mathbf{T b}$ & 0.77 & 0.44 & 0.62 & 1.75 & 2.10 & 2.30 \\
\hline Dy & 4.81 & 2.68 & 3.66 & 11.21 & 13.51 & 15.61 \\
\hline Но & 0.94 & 0.57 & 0.75 & 2.37 & 2.88 & 3.39 \\
\hline $\mathbf{E r}$ & 2.62 & 1.57 & 2.01 & 6.74 & 8.14 & 10.11 \\
\hline $\mathbf{T m}$ & 0.40 & 0.24 & 0.30 & 1.03 & 1.23 & 1.56 \\
\hline $\mathbf{Y b}$ & 2.54 & 1.64 & 1.86 & 6.66 & 7.77 & 10.24 \\
\hline $\mathbf{L u}$ & 0.40 & 0.28 & 0.31 & 1.06 & 1.23 & 1.64 \\
\hline $\mathbf{B a}$ & 1119 & 815 & 1216 & 1985 & 1401 & 1419 \\
\hline Th & 10.94 & 8.99 & 10.02 & 7.36 & 7.03 & 7.81 \\
\hline Nb & 17.61 & 12.64 & 13.55 & 23.86 & 19.82 & 23.28 \\
\hline Y & 26.24 & 15.81 & 23.96 & 62.02 & 74.28 & 90.28 \\
\hline Hf & 4.43 & 3.39 & 4.44 & 10.34 & 10.29 & 11.64 \\
\hline Ta & 1.64 & 1.30 & 1.25 & 1.33 & 1.32 & 1.39 \\
\hline $\mathbf{U}$ & 3.54 & 3.45 & 3.09 & 3.34 & 3.03 & 3.52 \\
\hline $\mathbf{P b}$ & 15.84 & 13.78 & 13.65 & 15.25 & 15.22 & 17.53 \\
\hline $\mathbf{R b}$ & 107.3 & 83.4 & 79.7 & 88.6 & 78.5 & 74.6 \\
\hline Cs & 3.29 & 3.35 & 2.45 & 2.92 & 2.78 & 2.90 \\
\hline $\mathrm{Sr}$ & 64 & 267 & 177 & 53 & 101 & 31 \\
\hline Sc & 3.6 & 3.8 & 3.3 & 4.8 & 5.3 & 3.8 \\
\hline $\mathrm{Zr}$ & 132 & 120 & 163 & 424 & 396 & 439 \\
\hline
\end{tabular}


Table 8 continued. Major and trace element data from XRF and ICP-MS.

\begin{tabular}{|c|c|c|c|c|c|c|}
\hline $\begin{array}{l}\text { Unit } \\
\text { Sample } \\
\end{array}$ & $\begin{array}{c}\text { DIT } \\
\text { MS-11-20 } \\
\end{array}$ & $\begin{array}{c}\text { STR } \\
\text { AS-SV-151 } \\
\end{array}$ & $\begin{array}{c}\text { STR } \\
\text { AS-SV-190 } \\
\end{array}$ & $\begin{array}{c}\text { DCT } \\
\text { AS-SV-243 } \\
\end{array}$ & $\begin{array}{c}\text { DMR } \\
\text { MS-08-DR2 } \\
\end{array}$ & $\begin{array}{c}\text { LIR } \\
\text { MS-LFR1 }\end{array}$ \\
\hline \multicolumn{7}{|c|}{ XRF analyses, normalized $100 \%$ volatile free, weight $\%$} \\
\hline $\mathrm{SiO}_{2}$ & 67.95 & 73.19 & 76.93 & 76.80 & 73.91 & 72.29 \\
\hline $\mathrm{TiO}_{2}$ & 1.101 & 0.35 & 0.19 & 0.208 & 0.33 & 0.70 \\
\hline $\mathbf{A l}_{2} \mathbf{O}_{3}$ & 14.55 & 14.57 & 12.66 & 11.28 & 14.11 & 12.69 \\
\hline $\mathrm{FeO}^{*}$ & 5.69 & 2.23 & 1.19 & 2.63 & 2.08 & 3.94 \\
\hline MnO & 0.128 & 0.053 & 0.037 & 0.062 & 0.04 & 0.09 \\
\hline MgO & 1.09 & 0.23 & 0.13 & 0.01 & 0.03 & 0.44 \\
\hline $\mathrm{CaO}$ & 2.97 & 1.99 & 0.81 & 0.14 & 2.08 & 1.73 \\
\hline $\mathrm{Na}_{2} \mathrm{O}$ & 3.12 & 3.86 & 4.12 & 4.19 & 3.78 & 2.51 \\
\hline $\mathbf{K}_{2} \mathbf{O}$ & 3.02 & 3.422 & 3.912 & 4.64 & 3.62 & 5.47 \\
\hline $\mathbf{P}_{2} \mathbf{O}_{5}$ & 0.375 & 0.097 & 0.023 & 0.026 & 0.03 & 0.14 \\
\hline \multicolumn{7}{|c|}{ XRF analyses, unnormalized ppm } \\
\hline $\mathbf{N i}$ & 3.6 & 2.5 & 3.0 & 1.8 & 0.0 & 0.0 \\
\hline $\mathrm{Cr}$ & 6.9 & 5.4 & 3.2 & 3.7 & 2.1 & 3.1 \\
\hline Sc & 16.4 & & & 1.4 & 10.8 & 11.1 \\
\hline $\mathbf{V}$ & 68.7 & 29.8 & 5.2 & 8.0 & 5.7 & 12.5 \\
\hline $\mathbf{B a}$ & 1296.4 & & & 63.7 & 1480.4 & 1259.3 \\
\hline $\mathbf{R b}$ & 54.1 & & & 115.5 & 77.2 & 150.6 \\
\hline $\mathrm{Sr}$ & 233.6 & & & 7.0 & 193.0 & 161.9 \\
\hline $\mathrm{Zr}$ & 272.4 & & & 768.7 & 362.8 & 287.7 \\
\hline $\mathbf{Y}$ & 50.5 & & & 56.5 & 45.8 & 40.0 \\
\hline $\mathbf{N b}$ & 17.7 & & & 55.8 & 14.1 & 17.7 \\
\hline $\mathbf{G a}$ & 21.3 & 15.7 & 14.4 & 28.1 & 20.0 & 18.3 \\
\hline $\mathbf{C u}$ & 6.6 & 7.2 & 2.7 & 3.3 & 3.0 & 1.9 \\
\hline $\mathbf{Z n}$ & 140.8 & 48.5 & 35.2 & 186.7 & 84.2 & 89.1 \\
\hline $\mathbf{P b}$ & 10.6 & & & 26.5 & 12.7 & 22.8 \\
\hline $\mathbf{L a}$ & 33.7 & & & 61.3 & 35.6 & 43.7 \\
\hline $\mathrm{Ce}$ & 67.7 & & & 149.6 & 67.6 & 85.6 \\
\hline Th & 5.6 & & & 11.0 & 8.8 & 15.9 \\
\hline Nd & 39.0 & & & 63.3 & 33.3 & 37.9 \\
\hline $\mathbf{U}$ & 1.8 & & & 2.1 & 3.5 & 5.0 \\
\hline
\end{tabular}


Table 8 continued. Major and trace element data from XRF and ICP-MS.

\begin{tabular}{|c|c|c|c|c|c|c|}
\hline $\begin{array}{l}\text { Unit } \\
\text { Sample } \\
\end{array}$ & $\begin{array}{c}\text { DIT } \\
\text { MS-11-20 } \\
\end{array}$ & $\begin{array}{c}\text { STR } \\
\text { AS-SV-151 } \\
\end{array}$ & $\begin{array}{c}\text { STR } \\
\text { AS-SV-190 } \\
\end{array}$ & $\begin{array}{c}\text { DCT } \\
\text { AS-SV-243 } \\
\end{array}$ & $\begin{array}{c}\text { DMR } \\
\text { MS-08-DR2 }\end{array}$ & $\begin{array}{c}\text { LIR } \\
\text { MS-LFR1 }\end{array}$ \\
\hline \multicolumn{7}{|c|}{ ICP-MS analyses, ppm } \\
\hline La & 33.49 & 25.41 & 29.51 & 62.92 & 35.07 & 45.52 \\
\hline $\mathrm{Ce}$ & 69.91 & 46.23 & 59.07 & 155.99 & 70.32 & 88.88 \\
\hline Pr & 9.12 & 5.36 & 7.04 & 17.03 & 8.77 & 10.72 \\
\hline Nd & 37.89 & 19.62 & 26.15 & 63.24 & 34.54 & 40.35 \\
\hline Sm & 8.81 & 3.82 & 5.67 & 13.96 & 7.79 & 8.62 \\
\hline $\mathbf{E u}$ & 2.38 & 0.88 & 0.80 & 0.71 & 1.58 & 1.67 \\
\hline Gd & 8.77 & 3.35 & 5.36 & 11.42 & 7.51 & 7.75 \\
\hline $\mathbf{T b}$ & 1.46 & 0.54 & 0.97 & 2.08 & 1.29 & 1.27 \\
\hline Dy & 9.25 & 3.26 & 6.22 & 12.60 & 8.23 & 7.63 \\
\hline Но & 1.93 & 0.67 & 1.31 & 2.36 & 1.71 & 1.53 \\
\hline $\mathbf{E r}$ & 5.32 & 1.88 & 3.88 & 6.42 & 4.91 & 4.16 \\
\hline $\mathbf{T m}$ & 0.78 & 0.29 & 0.60 & 0.98 & 0.75 & 0.61 \\
\hline $\mathbf{Y b}$ & 4.97 & 1.93 & 3.96 & 6.32 & 4.78 & 3.80 \\
\hline $\mathbf{L u}$ & 0.82 & 0.32 & 0.63 & 0.98 & 0.75 & 0.59 \\
\hline $\mathbf{B a}$ & 1319 & 1485.10 & 1254.51 & 71 & 1523 & 1277 \\
\hline Th & 5.32 & 7.70 & 8.46 & 11.30 & 6.83 & 16.37 \\
\hline Nb & 17.29 & 8.78 & 12.29 & 55.36 & 13.76 & 17.94 \\
\hline $\mathbf{Y}$ & 50.07 & 17.93 & 35.96 & 53.86 & 45.47 & 39.45 \\
\hline Hf & 7.10 & 4.59 & 5.38 & 17.81 & 8.80 & 7.92 \\
\hline Ta & 1.07 & 0.74 & 1.01 & 3.37 & 0.90 & 1.34 \\
\hline $\mathbf{U}$ & 2.53 & 3.67 & 3.42 & 2.19 & 2.73 & 5.26 \\
\hline $\mathbf{P b}$ & 10.65 & 13.91 & 13.10 & 24.61 & 13.19 & 23.73 \\
\hline $\mathbf{R b}$ & 53.7 & 86.65 & 90.49 & 114.2 & 77.5 & 151.1 \\
\hline Cs & 2.27 & 4.20 & 3.32 & 1.46 & 3.46 & 5.13 \\
\hline $\mathrm{Sr}$ & 239 & 231.02 & 76.82 & 10 & 192 & 162 \\
\hline Sc & 16.5 & 5.83 & 4.68 & 0.9 & 11.3 & 11.7 \\
\hline $\mathrm{Zr}$ & 278 & 171.00 & 176.24 & 800 & 375 & 296 \\
\hline
\end{tabular}


Table 8 continued. Major and trace element data from XRF and ICP-MS.

\begin{tabular}{|c|c|c|c|c|c|c|c|}
\hline $\begin{array}{l}\text { Unit } \\
\text { Sample }\end{array}$ & $\begin{array}{c}\text { STK } \\
\text { MS-11-45 }\end{array}$ & $\begin{array}{c}\text { SCT } \\
\text { MS-11-15 }\end{array}$ & $\begin{array}{c}\text { TFI } \\
\text { TF-88A }\end{array}$ & $\begin{array}{c}\text { IDL } \\
\text { MS-13-05 }\end{array}$ & $\begin{array}{c}\text { MCB } \\
\text { MS-13-09 }\end{array}$ & $\begin{array}{c}\text { VCR } \\
\text { MS-13-10 }\end{array}$ & $\begin{array}{c}\text { BLB } \\
\text { MS-13-12 }\end{array}$ \\
\hline \multicolumn{8}{|c|}{ XRF analyses, normalized $100 \%$ volatile free, weight $\%$} \\
\hline $\mathrm{SiO}_{2}$ & 76.73 & 73.80 & 77.19 & 76.31 & 73.59 & 76.84 & 77.00 \\
\hline $\mathrm{TiO}_{2}$ & 0.096 & 0.32 & 0.16 & 0.040 & 0.336 & 0.082 & 0.096 \\
\hline $\mathbf{A l}_{2} \mathbf{O}_{3}$ & 12.21 & 12.49 & 11.58 & 13.90 & 13.34 & 12.53 & 12.11 \\
\hline $\mathrm{FeO} *$ & 1.42 & 3.23 & 1.88 & 0.55 & 2.13 & 1.04 & 1.38 \\
\hline MnO & 0.035 & 0.07 & 0.03 & 0.097 & 0.044 & 0.018 & 0.049 \\
\hline MgO & 0.03 & 0.05 & 0.00 & 0.03 & 0.35 & 0.07 & 0.11 \\
\hline $\mathrm{CaO}$ & 0.46 & 0.83 & 0.32 & 0.61 & 1.23 & 0.44 & 0.41 \\
\hline $\mathrm{Na}_{2} \mathrm{O}$ & 3.58 & 3.40 & 3.34 & 3.97 & 2.72 & 3.09 & 3.99 \\
\hline $\mathbf{K}_{2} \mathbf{O}$ & 5.42 & 5.79 & 5.51 & 4.47 & 6.17 & 5.87 & 4.65 \\
\hline $\mathbf{P}_{2} \mathbf{O}_{5}$ & 0.028 & 0.02 & 0.01 & 0.019 & 0.076 & 0.015 & 0.193 \\
\hline \multicolumn{8}{|c|}{ XRF analyses, unnormalized ppm } \\
\hline $\mathbf{N i}$ & 0.8 & 0.4 & 1.9 & 0.0 & 4.4 & 0.9 & 13.1 \\
\hline $\mathbf{C r}$ & 3.1 & 2.6 & 2.1 & 4.5 & 4.3 & 3.0 & 4.4 \\
\hline Sc & 0.4 & 1.4 & 0.0 & 6.1 & 4.9 & 1.1 & 1.0 \\
\hline $\mathbf{v}$ & 1.6 & 5.2 & 2.8 & 1.0 & 19.5 & 3.6 & 8.3 \\
\hline $\mathbf{B a}$ & 20.3 & 1768.4 & 130.6 & 63.7 & 843.6 & 87.0 & 75.2 \\
\hline $\mathbf{R b}$ & 152.2 & 134.9 & 146.2 & 130.4 & 143.3 & 178.2 & 144.4 \\
\hline $\mathrm{Sr}$ & 4.1 & 27.4 & 3.0 & 11.7 & 90.9 & 11.0 & 8.6 \\
\hline $\mathbf{Z r}$ & 304.6 & 669.1 & 670.5 & 45.5 & 221.7 & 163.3 & 282.8 \\
\hline $\mathbf{Y}$ & 75.8 & 93.3 & 121.6 & 35.0 & 36.5 & 64.5 & 155.0 \\
\hline $\mathbf{N b}$ & 50.0 & 41.6 & 47.1 & 19.9 & 16.4 & 40.3 & 52.2 \\
\hline $\mathbf{G a}$ & 21.5 & 24.3 & 26.1 & 17.0 & 16.3 & 21.5 & 23.1 \\
\hline $\mathbf{C u}$ & 5.5 & 5.6 & 5.2 & 1.7 & 6.9 & 4.6 & 10.1 \\
\hline $\mathbf{Z n}$ & 112.8 & 165.3 & 193.1 & 43.4 & 43.4 & 79.2 & 108.6 \\
\hline $\mathbf{P b}$ & 26.6 & 22.6 & 27.7 & 20.0 & 18.1 & 27.9 & 24.2 \\
\hline La & 59.7 & 62.4 & 73.4 & 7.7 & 40.3 & 45.4 & 136.5 \\
\hline $\mathrm{Ce}$ & 118.7 & 139.0 & 153.0 & 19.7 & 73.0 & 95.7 & 143.9 \\
\hline Th & 14.5 & 13.5 & 16.6 & 4.9 & 12.5 & 17.9 & 15.0 \\
\hline Nd & 54.0 & 68.4 & 76.1 & 7.7 & 30.3 & 40.9 & 112.6 \\
\hline $\mathbf{U}$ & 5.6 & 5.6 & 5.0 & 4.5 & 6.1 & 6.7 & 4.5 \\
\hline
\end{tabular}


Table 8 continued. Major and trace element data from XRF and ICP-MS.

\begin{tabular}{|c|c|c|c|c|c|c|c|}
\hline $\begin{array}{l}\text { Unit } \\
\text { Sample }\end{array}$ & $\begin{array}{c}\text { STK } \\
\text { MS-11-45 }\end{array}$ & $\begin{array}{c}\text { SCT } \\
\text { MS-11-15 }\end{array}$ & $\begin{array}{c}\text { TFI } \\
\text { TF-88A }\end{array}$ & $\begin{array}{c}\text { IDL } \\
\text { MS-13-05 }\end{array}$ & $\begin{array}{c}\text { MCB } \\
\text { MS-13-09 }\end{array}$ & $\begin{array}{c}\text { VCR } \\
\text { MS-13-10 }\end{array}$ & $\begin{array}{c}\text { BLB } \\
\text { MS-13-12 }\end{array}$ \\
\hline \multicolumn{8}{|c|}{$\begin{array}{l}\text { ICP-MS analyses, } \\
\text { ppm }\end{array}$} \\
\hline La & 59.84 & 67.84 & 76.27 & 8.47 & 40.58 & 45.44 & 139.92 \\
\hline $\mathrm{Ce}$ & 119.95 & 148.11 & 164.67 & 19.69 & 77.53 & 96.58 & 151.34 \\
\hline Pr & 14.36 & 17.63 & 20.20 & 2.46 & 8.99 & 11.56 & 29.59 \\
\hline Nd & 52.78 & 71.42 & 81.25 & 8.89 & 32.83 & 43.01 & 116.71 \\
\hline Sm & 12.28 & 16.45 & 19.41 & 3.06 & 6.67 & 10.28 & 25.11 \\
\hline Eu & 0.14 & 3.36 & 1.18 & 0.23 & 0.90 & 0.16 & 2.88 \\
\hline Gd & 11.67 & 16.33 & 19.95 & 3.72 & 5.95 & 9.76 & 26.10 \\
\hline $\mathbf{T b}$ & 2.12 & 2.82 & 3.57 & 0.80 & 1.02 & 1.77 & 4.21 \\
\hline Dy & 13.35 & 17.70 & 22.89 & 5.44 & 6.45 & 11.40 & 25.23 \\
\hline Но & 2.73 & 3.69 & 4.81 & 1.17 & 1.33 & 2.35 & 5.16 \\
\hline $\mathbf{E r}$ & 7.72 & 10.39 & 13.43 & 3.35 & 3.87 & 6.62 & 13.63 \\
\hline $\mathbf{T m}$ & 1.17 & 1.54 & 2.01 & 0.52 & 0.59 & 0.99 & 1.92 \\
\hline Yb & 7.34 & 9.76 & 12.54 & 3.34 & 3.86 & 6.25 & 11.25 \\
\hline Lu & 1.14 & 1.62 & 1.94 & 0.51 & 0.63 & 0.96 & 1.71 \\
\hline $\mathbf{B a}$ & 22 & 1870 & 135.18 & 67 & 856 & 92 & 76 \\
\hline Th & 14.54 & 14.41 & 17.30 & 4.90 & 11.89 & 16.93 & 14.66 \\
\hline Nb & 50.55 & 41.26 & 47.56 & 19.18 & 15.94 & 40.51 & 52.65 \\
\hline $\mathbf{Y}$ & 72.96 & 93.74 & 122.52 & 33.82 & 35.98 & 62.76 & 153.14 \\
\hline Hf & 10.52 & 16.85 & 19.38 & 2.78 & 6.48 & 7.01 & 10.54 \\
\hline Ta & 3.33 & 2.42 & 2.98 & 1.68 & 1.37 & 3.00 & 3.53 \\
\hline $\mathbf{U}$ & 5.67 & 4.29 & 5.12 & 4.52 & 5.12 & 6.53 & 5.27 \\
\hline $\mathbf{P b}$ & 24.96 & 21.70 & 26.65 & 17.87 & 17.69 & 25.82 & 23.70 \\
\hline $\mathbf{R b}$ & 153.9 & 134.9 & 155.62 & 131.2 & 141.1 & 176.6 & 144.4 \\
\hline Cs & 4.18 & 3.16 & 4.05 & 4.93 & 3.33 & 5.00 & 3.96 \\
\hline $\mathrm{Sr}$ & 6 & 29 & 5.06 & 13 & 96 & 13 & 10 \\
\hline Sc & 0.5 & 1.4 & 0.09 & 4.5 & 4.7 & 1.1 & 0.5 \\
\hline $\mathrm{Zr}$ & 310 & 719 & 714.39 & 49 & 226 & 169 & 292 \\
\hline
\end{tabular}




\section{APPENDIX C: RADIOGENIC ISOTOPES}

\section{Methods}

\section{Sample Preparation}

Selecting Crystals, Groundmass, and Whole Rock Powders

Whole rock samples were chipped and sieved into three size fractions: 0.991-2 $\mathrm{mm}, 0.425-0.991 \mathrm{~mm}$, and 0.104-0.425 $\mathrm{mm}$. These chips were then handpicked under a microscope for either fresh groundmass or feldspar crystals, ensuring they were free of inclusions and lacked alteration due to weathering. Approximately 0.5 grams of groundmass or feldspar crystals was collected for each sample. Whole rock powders were prepared for selected samples using a tungsten carbide ring mill at the GeoAnalytical Lab at WSU.

\section{Etching Crystals}

Sample etching, digestion, chromatography and analyses were conducted at the Isotope Lab at NMSU. For the samples with feldspar crystals, between 15 and 30 crystals were selected with a LEICA M165C microscope to be etched. The purpose of etching was to remove adhering groundmass and to accentuate cleavage/striations to ensure accurate identification of plagioclase and/or alkali feldspar and not quartz. Crystals were placed in plastic beakers with $\sim 2 \mathrm{~mL} 10 \%$ HF for 30 minutes. The crystals were then rinsed in ultrafiltered $\mathrm{H}_{2} \mathrm{O}$, and placed in a sonicating bath for 15 minutes. Among the crystals etched, approximately ten crystals that did not display altered surfaces (e.g., discoloration, adhering minerals, inclusions) were handpicked for digestion. 


\section{Digestion}

\section{Groundmass (Sr)}

For each sample, $\sim 70 \mathrm{mg}$ were weighed and placed in a $15 \mathrm{~mL} \mathrm{Teflon}^{\mathrm{TM}}$ beaker. Samples were dissolved in the cleanroom at NMSU over the course of three days. First, $\sim 2 \mathrm{~mL}$ of concentrated $\mathrm{HNO}_{3}$ and $\sim 2 \mathrm{~mL}$ of concentrated $\mathrm{HF}$, both doubly distilled, were added to each beaker. Beakers were sealed and left on a hotplate overnight at $100^{\circ} \mathrm{C}$. After $\sim 18$ hours, the lids were removed and the acid was evaporated. Next, $\sim 4 \mathrm{~mL}$ of $7 \mathrm{~N}$ $\mathrm{HNO}_{3}$ was added and the beakers were sealed and left on a hotplate overnight at $100^{\circ} \mathrm{C}$. After $\sim 18$ hours, the lids were removed and the acid was evaporated. Next, the samples were dissolved in $\sim 4 \mathrm{~mL}$ of $6 \mathrm{~N} \mathrm{HCl}$ and the beakers were sealed and left on a hotplate overnight at $100^{\circ} \mathrm{C}$. The final step was drying the samples and redissolving them in $1 \mathrm{~mL}$ 2.5N HCl. Samples were then transferred to $1.5 \mathrm{~mL}$ micro-centrifuge tubes and centrifuged at $5000 \mathrm{rpm}$ for three minutes in preparation for column chromatography. The purpose of centrifuging was to separate any undissolved material, of which there was none. From the $1 \mathrm{~mL}$ volume of sample, a $0.5 \mathrm{~mL}$ aliquot of $2.5 \mathrm{~N} \mathrm{HCl}$ sample solution was used for column chromatography.

Whole Rock Powder $(\mathrm{Pb})$

For each sample, between 100-150 mg was weighed and placed in a $60 \mathrm{~mL}$ Teflon ${ }^{\mathrm{TM}}$ beaker. The digestion steps were the same as those listed above for groundmass, but $\sim 3 \mathrm{~mL}$ of concentrated $\mathrm{HNO}_{3}$ and $\sim 3 \mathrm{~mL}$ of concentrated $\mathrm{HF}$ were added to each beaker during the first step, $4 \mathrm{~mL}$ of $7 \mathrm{~N} \mathrm{HNO}_{3}$ was added during the second step, and $\sim 4 \mathrm{~mL}$ of $6 \mathrm{~N} \mathrm{HCl}$ was added during the third step. 


\section{Feldspars (Sr)}

For each sample, the weight of the ten feldspar crystals was recorded and the sample was placed in a $7 \mathrm{~mL}$ or $3 \mathrm{~mL}$ Teflon ${ }^{\mathrm{TM}}$ beaker. Digestion steps were the same as those listed above for groundmass samples, but $\sim 2 \mathrm{~mL}$ of concentrated $\mathrm{HNO}_{3}$ and $\sim 2 \mathrm{~mL}$ of concentrated $\mathrm{HF}$ were added to each $7 \mathrm{~mL}$ beaker and $\sim 1 \mathrm{~mL}$ of concentrated $\mathrm{HNO}_{3}$ and $\sim 2 \mathrm{~mL}$ of concentrated HF were added to each $3 \mathrm{~mL}$ beaker for the first step. For the second step, $\sim 1 \mathrm{~mL}$ of $7 \mathrm{~N} \mathrm{HNO}_{3}$ was added to each beaker. For the third step, $\sim 2 \mathrm{~mL}$ of $6 \mathrm{~N} \mathrm{HCl}$ was added to each beaker.

\section{Chromatography Preparation and Sample Purification}

\section{$\underline{\text { Strontium }}$}

Cation exchange resin was used to purify elemental strontium. The columns used were $0.7 \mathrm{~cm}$ by $15 \mathrm{~cm}^{\text {Pyrex }^{\mathrm{TM}}}$ columns with $22 \mathrm{~mL}$ reservoirs and $\sim 4 \mathrm{~mL}$ cation exchange resin. After pretreating the columns with $10 \mathrm{~mL} 2.5 \mathrm{~N} \mathrm{HCl}, 0.5 \mathrm{~mL}$ of each sample, removed from the top portion of the $1.0 \mathrm{~mL}$ centrifuged sample solution, was loaded onto columns via a pipette. Next, two $0.5 \mathrm{~mL}$ washes of $2.5 \mathrm{~N} \mathrm{HCl}$ were added by dropping liquid along the reservoir sides to ensure complete sample loading onto the resin bed. Next, $2 \mathrm{~mL}$ of $2.5 \mathrm{~N} \mathrm{HCl}$, followed by $9.5 \mathrm{~mL}$ of $2.5 \mathrm{~N} \mathrm{HCl}$, and then by $5 \mathrm{~mL}$ of $2.5 \mathrm{~N} \mathrm{HCl}$ were used to remove elements other than strontium and the REEs. Each step was initiated after all acid had drained from the reservoir into the resin. Strontium was then collected in a $15 \mathrm{~mL}$ beaker using $6 \mathrm{~mL}$ of $2.5 \mathrm{~N} \mathrm{HCl}$. Those purified strontium solutions were dried overnight in preparation for thermal ionization mass spectrometry 
analysis. The columns were subsequently washed with $25 \mathrm{~mL}$ of $6 \mathrm{~N} \mathrm{HCl}$ to remove rare earth elements from the resin and then backwashed with $\mathrm{H}_{2} \mathrm{O}$.

Lead

To obtain pure $\mathrm{Pb}$ separates, washes collected from cation exchange chromatography were first dried and dissolved in $1 \mathrm{~N} \mathrm{HBr} .0 .6 \mathrm{~cm}$ by $8 \mathrm{~cm}^{\text {Pyrex }}{ }^{\mathrm{TM}}$ columns with $6 \mathrm{~mL}$ reservoirs were filled with $\sim 2 \mathrm{~mL}$ of anion exchange resin. Columns were prepared using $3 \mathrm{~mL}$ of $1 \mathrm{~N} \mathrm{HBr}$ prior to sample loading. Each sample was loaded onto a column in a $0.5 \mathrm{~mL}$ aliquot, followed by two washes of $0.5 \mathrm{~mL}$ of $1 \mathrm{~N} \mathrm{HBr}$ to ensure all sample was loaded onto the resin. The columns were then washed four times with $3 \mathrm{~mL}$ of $1 \mathrm{~N} \mathrm{HBr}$. Each step was initiated after all acid had drained from the reservoir into the resin. $\mathrm{Pb}$ was collected using a strip technique with a wash of $1 \mathrm{~mL}$ of $\mathrm{H}_{2} \mathrm{O}$ followed by a two washes of $3 \mathrm{~mL}$ of $1 \mathrm{~N} \mathrm{HNO}_{3}$. Columns were washed with $3 \mathrm{~mL}$ of $6 \mathrm{~N} \mathrm{HCl}, 1 \mathrm{~mL}$ of $\mathrm{H}_{2} \mathrm{O}, 3 \mathrm{~mL}$ of $7 \mathrm{~N} \mathrm{HNO}_{3}$, and $3 \mathrm{~mL}$ of $1 \mathrm{~N} \mathrm{HNO}_{3}$ to clean the resin. Purified $\mathrm{Pb}$ solutions were placed on the hot plate and dried.

\section{Mass Spectrometry}

Strontium Loading and Analysis

Purified strontium samples were analyzed using a VG 54 Sector Thermal Ionization Mass Spectrometer (TIMS) on center only Cathodeon beads with Re filaments. The filaments were outgassed and left to oxidize for at least 48 hours prior to loading. A dilution factor was determined for each sample to ensure between 10 and $100 \mathrm{ng} \mathrm{Sr}$ would be loaded on the filament. In general, $\sim 100$ microliters of $5 \% \mathrm{HNO}_{3}$ were added to 
the dried samples and left to dissolve for at least one hour. One microliter of both dissolved strontium solution $(\sim 1 \%, 1 \mu \mathrm{L}$ of $100 \mu \mathrm{L})$ and tantalum oxide dissolved in $\sim 5 \%$ phosphoric acid were loaded onto the center filament and allowed to air dry. Samples were preheated in atmosphere to volatilize the phosphoric gas and to bind strontium and tantalum oxide. Samples were then loaded into the TIMS and the TIMS was pumped down to a vacuum of $<10^{-5}$ atm. Filaments were degassed at $\sim 1.5$ amps under vacuum for a minute. Approximately 2.4 amps of current were required to obtain $\sim 3 \mathrm{~V}^{88} \mathrm{Sr}$ for analysis. Strontium isotopes were analyzed using five Faraday collectors in dynamic mode with ratios normalized to ${ }^{86} \mathrm{Sr} /{ }^{88} \mathrm{Sr}=0.1194$ to account for mass fractionation.

\section{Lead Analysis}

The purified lead samples were analyzed using a Thermo Scientific multicollector inductively coupled plasma mass spectrometer (MC-ICP-MS) at University of Wyoming High-Precision Isotope Laboratory. Samples were dissolved in $2 \% \mathrm{HNO}_{3}+0.01 \% \mathrm{HF}$. Thallium was added to each sample to correct for mass fractionation with $\mathrm{Pb} / \mathrm{Tl}$ ratio target of 3 to 1 . Samples were introduced into the plasma using a desolvating nebulizer. Lead and thallium isotopes were analyzed in static mode using six Faraday collectors. Samples were doped with NBS 997 thallium standard and mass discrimination was adjusted to ${ }^{205} \mathrm{Tl} /{ }^{203} \mathrm{Tl}=2.387075$.

\section{Results}

NBS 987 Sr standard results averaged $0.710288(n=5)$. For samples that had $\mathrm{Sr}$ concentration less than 15 ppm as measured by ICP-MS, Sr and Rb concentrations for 
feldspars and groundmass were determined by isotope dilution using a high $\mathrm{Rb} / \mathrm{Sr}$ spike. Concentrations of $\mathrm{Rb}$ and $\mathrm{Sr}$ determined by isotope dilution are considered accurate to about $1 \%$. There were four groundmass samples that had age-corrected $\mathrm{Sr}$ ratios much lower than would be expected for this region: TF-88A, MS-13-12, MS-13-10, and EJ-1203 (Table 5). While the corresponding feldspar samples had ${ }^{87} \mathrm{Sr}^{86} \mathrm{Sr}_{\mathrm{i}}$ ranging from 0.7036 to $0.7049,{ }^{87} \mathrm{Sr}^{86} \mathrm{Sr}_{\mathrm{i}}$ of the groundmass ranged from 0.6832 to 0.7020 . These unrealistic ratios likely reflect the extremely high $\mathrm{Rb} / \mathrm{Sr}$ ratio of groundmass, which ranged from 13.6 to 31.2. The $\mathrm{Rb}$ and $\mathrm{Sr}$ concentrations for each of these samples were determined by isotope dilution. A minor change in the $\mathrm{Sr}$ concentration when it is small relative to the $\mathrm{Rb}$ concentration can greatly influence the $\mathrm{Rb} / \mathrm{Sr}$ ratio, which is a critical aspect of age corrected initial ${ }^{87} \mathrm{Sr} /{ }^{86} \mathrm{Sr}$ ratios:

$$
{ }^{87} \mathrm{Sr}{ }^{86} \mathrm{Sr} r_{\text {sample }}={ }^{87} \mathrm{Sr} \gamma^{86} \mathrm{Sr} \text { initial }+{ }^{87} \mathrm{Rb}{ }^{86} \mathrm{Sr}\left(e^{\lambda t}-1\right) \quad \text { Eq. C-1 }
$$

where $t$ is the age of the sample and $\lambda$ is the decay constant $\left(1.42 \times 10^{-11} \mathrm{yr}^{-1}\right)$. The age, Rb, and $\mathrm{Sr}$ concentrations of the samples are available in Error! Reference source not

\section{found.}

We believe that the ratios for TF-88A, MS-13-12, MS-13-10, and EJ-12-03 are incorrect and reflect the challenges of measuring the ${ }^{87} \mathrm{Sr} /{ }^{86} \mathrm{Sr}$ in a sample that has a low $\mathrm{Sr}$ concentration relative to $\mathrm{Rb}$. There is likely something happening to the $\mathrm{Rb} / \mathrm{Sr}$ of the groundmass in these rhyolites post-eruption. 
Table 9. Age, Rb, and $\mathrm{Sr}$ concentration for calculating ${ }^{87} \mathrm{Sr} /{ }^{86} \mathrm{Sr}_{\mathrm{i}}$ (Eq. C-1). For $\mathrm{Rb}$ and $\mathrm{Sr}$ concentrations, WR (whole rock) is from ICP-MS while GM (groundmass) and fsp (feldspar) are from isotope dilution. If isotope dilution was not used to determine $\mathrm{Rb}$ and $\mathrm{Sr}$ concentration for feldspar samples, estimated partition coefficients were 0.25 for $\mathrm{Rb}$ and 2 for $\mathrm{Sr}$.

\begin{tabular}{|c|c|c|c|c|c|c|c|c|}
\hline \multicolumn{2}{|c|}{ Sample } & \multirow[t]{2}{*}{$\begin{array}{l}\text { Age } \\
(\mathrm{Ma})^{13}\end{array}$} & \multicolumn{2}{|c|}{$\begin{array}{lr}\mathrm{Rb} & \mathrm{Sr} \\
(\mathrm{WR}, \mathrm{ppm})\end{array}$} & \multicolumn{2}{|c|}{$\begin{array}{lr}\mathrm{Rb} & \mathrm{Sr} \\
(\mathrm{GM}, \mathrm{ppm})\end{array}$} & \multicolumn{2}{|c|}{$\begin{array}{cr}\mathrm{Rb} & \mathrm{Sr} \\
(\mathrm{fsp}, \mathrm{ppm})\end{array}$} \\
\hline \multicolumn{8}{|c|}{ Owyhee locality } & \\
\hline OMR & EJ-12-12 & $15.94^{2}$ & 160 & 37 & & & & \\
\hline JCR & EJ-12-13B & $10.66^{3}$ & 84 & 285 & & & & \\
\hline YMR & EJ-12-14 & $15.76^{2}$ & 143 & 24 & & & & \\
\hline DAM & EJ-12-15 & $13.58^{4}$ & 87 & 256 & & & & \\
\hline $\mathrm{SCT}$ & MS-11-15 & $15.74^{5}$ & 135 & 29 & & & & \\
\hline TFI & TF-88A & $15.74^{5}$ & 156 & 5 & 152 & 3.2 & 54.6 & 10.7 \\
\hline \multicolumn{9}{|c|}{ Littlefield/Cottonwood Mountain } \\
\hline LIR & EJ-12-10 & $16.75^{2}$ & 109 & 147 & & & & \\
\hline CMR & EJ-12-16 & $15.8^{6}$ & 146 & 185 & & & & \\
\hline $\mathrm{RBC}$ & EJ-12-17 & $17.01^{2}$ & 150 & 172 & & & & \\
\hline LIR & MS-LFR1 & $16.9^{7}$ & 151 & 162 & & & 1.46 & 666 \\
\hline \multicolumn{9}{|c|}{ Dinner Creek } \\
\hline DIT & EJ-12-08 & $\sim 16.0^{1}$ & 69 & 44 & & & & \\
\hline DIT & CR-U35a & $\sim 15.5^{1}$ & 89 & 53 & & & 4.72 & 339 \\
\hline DIT & MS-PCIT 1-A & $15.28^{8}$ & 101 & 79 & & & & \\
\hline DIT & MS-12-29.1 & $16.16^{8}$ & 75 & 31 & & & 0.74 & 91.8 \\
\hline DIT & MS- $11-20^{14}$ & $14.84^{8}$ & 54 & 239 & & & 7.86 & 285 \\
\hline \multicolumn{9}{|c|}{ Northern locality } \\
\hline UNI & CR-U3A & $\sim 16.5^{1}$ & 107 & 64 & & & & \\
\hline UNI & CR-U4B & $16.53^{2}$ & 83 & 267 & & & 0.55 & 444 \\
\hline UNI & MS-12-14b & $\sim 16.5^{1}$ & 80 & 177 & & & 0.35 & 885 \\
\hline DMR & EJ-12-23A & $15.59^{2}$ & 93 & 96 & & & 2.37 & 1,721 \\
\hline DMR & EJ-12-23B & $\sim 15.5^{1}$ & 122 & 37 & & & & \\
\hline DMR & MS-08-DR2 & $\sim 15.5^{1}$ & 77 & 192 & & & & \\
\hline IRM & EJ-12-22B & $\sim 15^{1}$ & 36 & 474 & & & & \\
\hline \multicolumn{9}{|c|}{ Strawberry Mountain } \\
\hline STR & AS-SV-151 & $16.16^{10}$ & 87 & 231 & & & & \\
\hline STR & AS-SV-190 & $14.79^{10}$ & 90 & 77 & & & & \\
\hline \multicolumn{9}{|c|}{ Drewsey locality } \\
\hline TND & EJ-12-20 & $\sim 12^{1}$ & 108 & 21 & & & & \\
\hline TSD & EJ-12-19 & $\sim 12^{1}$ & 109 & 31 & & & & \\
\hline BER & EJ-12-07 & $16.29^{2}$ & 51 & 159 & & & & \\
\hline BLB & MS-13-12 & $\sim 14^{1}$ & 177 & 13 & 161.6 & 6.4 & 44.5 & 3.5 \\
\hline \multicolumn{9}{|c|}{ Southern locality } \\
\hline CBR & EJ-12-05B & $9.54^{11}$ & 169 & 108 & & & & \\
\hline SCR & EJ-12-06A & $16.01^{2}$ & 99 & 133 & & & & \\
\hline STK & MS-11-45 & $\sim 10.7^{1}$ & 154 & 6 & 160.2 & 2.6 & 48.2 & 15.1 \\
\hline MCB & MS-13-09 & $\sim 15^{1}$ & 141 & 96 & 142.1 & 40.1 & 332 & 531 \\
\hline VCR & MS-13-10 & $11.1^{9}$ & 144 & 10 & 326.6 & 1.5 & 87.8 & 30.8 \\
\hline DCT & AS-SV-243 & $9.74^{12}$ & 116 & 7 & & & & \\
\hline \multicolumn{9}{|c|}{ Western locality } \\
\hline DNB & EJ-12-01 & $\sim 14^{1}$ & 75 & 117 & & & & \\
\hline
\end{tabular}




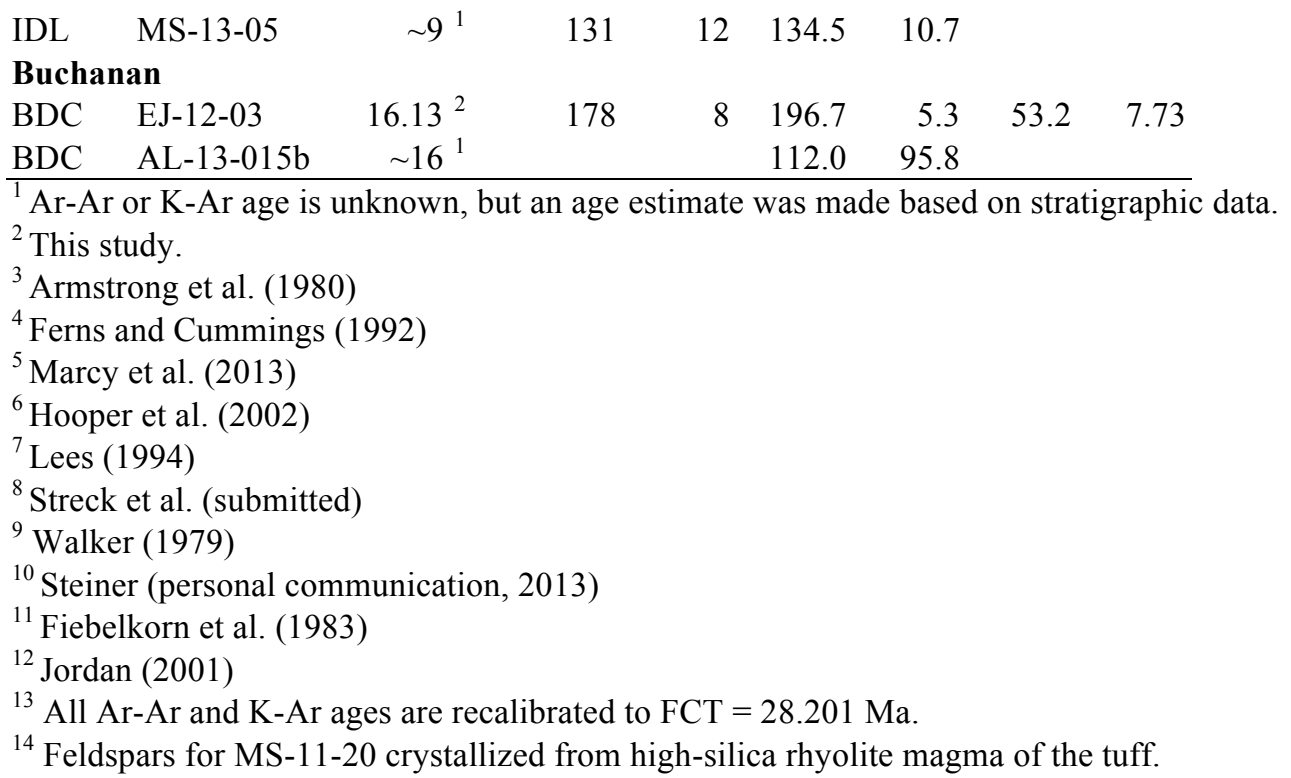

${ }^{1} \mathrm{Ar}-\mathrm{Ar}$ or $\mathrm{K}-\mathrm{Ar}$ age is unknown, but an age estimate was made based on stratigraphic data.

${ }^{2}$ This study.

${ }^{3}$ Armstrong et al. (1980)

${ }^{4}$ Ferns and Cummings (1992)

${ }^{5}$ Marcy et al. (2013)

${ }^{6}$ Hooper et al. (2002)

${ }^{7}$ Lees (1994)

${ }^{8}$ Streck et al. (submitted)

${ }^{9}$ Walker (1979)

${ }^{10}$ Steiner (personal communication, 2013)

${ }^{11}$ Fiebelkorn et al. (1983)

12 Jordan (2001)

${ }^{13}$ All Ar-Ar and K-Ar ages are recalibrated to FCT $=28.201 \mathrm{Ma}$.

${ }^{14}$ Feldspars for MS-11-20 crystallized from high-silica rhyolite magma of the tuff. 


\section{APPENDIX D: OXYGEN ISOTOPES}

\section{Methods}

Oxygen isotope analyses were performed at University of Oregon in the Stable Isotope Laboratory. Analyses were performed on quartz, plagioclase, and alkali feldspar crystals, and whole rock powders. Grains were pretreated with 2 Torr $\mathrm{BrF}_{5}$ overnight to remove surface and water contamination. Oxygen was isolated from the sample using laser fluorination with a $35 \mathrm{~W}$ Newwave $\mathrm{CO}_{2}$ IR laser and $\mathrm{BrF}_{5}$ reagent. Released oxygen gas was analyzed using a Finnigan MAT 253 large radius 10kv gas source mass spectrometer. Ratios for these analyses are shown in Table 4.

Equations (i.e. correction factors) have been developed to covert mineral $\delta^{18} \mathrm{O}$ data to bulk rock $\delta^{18} \mathrm{O}$ (Bindeman et al., 2004). The MELTS program was used to determine how $\delta^{18} \mathrm{O}$ changes with $\mathrm{SiO}_{2}$ to treat melts (i.e., bulk rock) as mixtures of normative minerals. The correction factor for plagioclase, quartz, and alkali feldspar using bulk rock $\mathrm{SiO}_{2}$ concentrations is:

$$
\begin{array}{cc}
\text { Plagioclase: } \delta^{18} O_{\text {magma }}=0.027\left(\mathrm{SiO}_{2} w t^{o} \%_{\text {wholerock }}\right)-1.45+\delta^{18} O_{\text {plag }} & \text { Eq. D-1 } \\
\text { Quartz: } \delta^{18} O_{\text {magma }}=\delta^{18} O_{q t z}-0.45 & \text { Eq. D-2 } \\
\text { Alkali Feldspar: } \delta^{18} O_{\text {magma }}=\delta^{18} O_{\text {kspar }}+0.29 & \text { Eq. D-3 }
\end{array}
$$

with equation D-1 based on calculations by Bindeman et al. (2004), equation D-2 based on measurements in the Bishop Tuff (Bindeman and Valley, 2002), and equation D-3 based on the average $\delta^{18} O$, melt-sanidine value for seventeen sanidine crystals analyzed in the Timber Mountain/Oasis Valley Caldera Complex in southwest Nevada (Bindeman and Valley, 2003). Approximate bulk rock $\delta^{18} \mathrm{O}$ values can be determined adding this 
correction factor to single grain data. This correction factor will not be valid when applied to xenocrysts or crystals involved in magma mixing because the bulk rock $\mathrm{SiO}_{2}$ content is not the same as the melt the minerals crystallized (Bindeman et al., 2004). 


\section{APPENDIX E: AGE DATING}

\section{Background}

Dating using the Ar-Ar system is based on the formation of ${ }^{39} \mathrm{Ar}$ by the irradiation of potassium bearing samples with thermal and fast neutrons in a nuclear reactor. The desired reaction is ${ }_{19}^{39} \mathrm{~K}(n, p){ }_{18}^{39} \mathrm{Ar} .{ }^{39} \mathrm{Ar}$ is unstable and decays to ${ }^{39} \mathrm{~K}$ by $\beta$-emission with a half-life of 269 years. This short half-life guarantees ${ }^{39} \mathrm{Ar}$ is absent in the sample beforehand and that ${ }^{39} \mathrm{Ar}$ can be treated as though it were stable during the short period involved in analyses (Faure and Mensing, 2005). This dating technique is more powerful than K-Ar because it can distinguish samples that have experienced argon loss or gain from those that have remained in closed systems since formation (Brownlow, 1995). By subjecting a sample to increasing temperature, the ${ }^{40} \mathrm{Ar} /{ }^{39} \mathrm{Ar}$ gas ratio released can be measured and a series of dates can be obtained from this fractional release. The plateau is the margin on the incremental heating plot that is used to calculate the age of the sample. To determine whether an incremental heating experiment yields meaningful crystallization ages, four criteria were proposed by Fleck et al. (1977) and Pringle (1993): high temperature plateaus in the age spectra should include more than three incremental heating steps and at least $50 \%$ of the total amount of ${ }^{39}$ Ar released; the plateau and isochron ages should be concordant at the $95 \%$ confidence level; the ${ }^{40} \mathrm{Ar} /{ }^{36} \mathrm{Ar}$ intercepts on the isochron diagrams should be equal to the atmospheric value of 295.5 at the $95 \%$ confidence level; and the mean squared weighted deviations for the plateau ages and the isochron ages should be sufficiently small compared to F-statistic distributions. 


\section{Methods}

Incremental heating experiments were performed at the ${ }^{40} \mathrm{Ar} /{ }^{39} \mathrm{Ar}$ Geochronology Laboratory at OSU on fresh feldspar and groundmass separates that were acid-rinsed prior to irradiation. All samples were loaded into quartz vials with small quantities of mineral monitor FCT-3 biotite and irradiated at the OSU TRIGA research reactor. Samples that were analyzed via the single collector MAP 215-50 mass spectrometer were heated in a double-vacuum, thermocouple-controlled, resistance furnace. Each heating step was followed by gas cleanup and then Ar isotopic composition analysis. Some of the samples were measured on the ARGUS VI, which is a multi-collector mass spectrometer. ArArCALC software provided by Koppers (2002) reduced the isotopic data and calculated age. Resulting age spectra are based on the younger Fish Canyon Tuff (FCT) age of 28.020 Ma or 28.030 Ma (Figure 32). For final age calculations, the samples ages were later recalculated using a FCT age of 28.201 (Kuiper et al., 2008). Further details of the analytical procedures are described in Duncan and Keller (2004). Plateaus generated from the incremental heating experiments are displayed in Figure 32. All analyses were undertaken using the MAP 215-50 mass spectrometer except for EJ-12-10, EJ-12-17, and EJ-12-23A, which were analyzed on the ARGUS VI. 

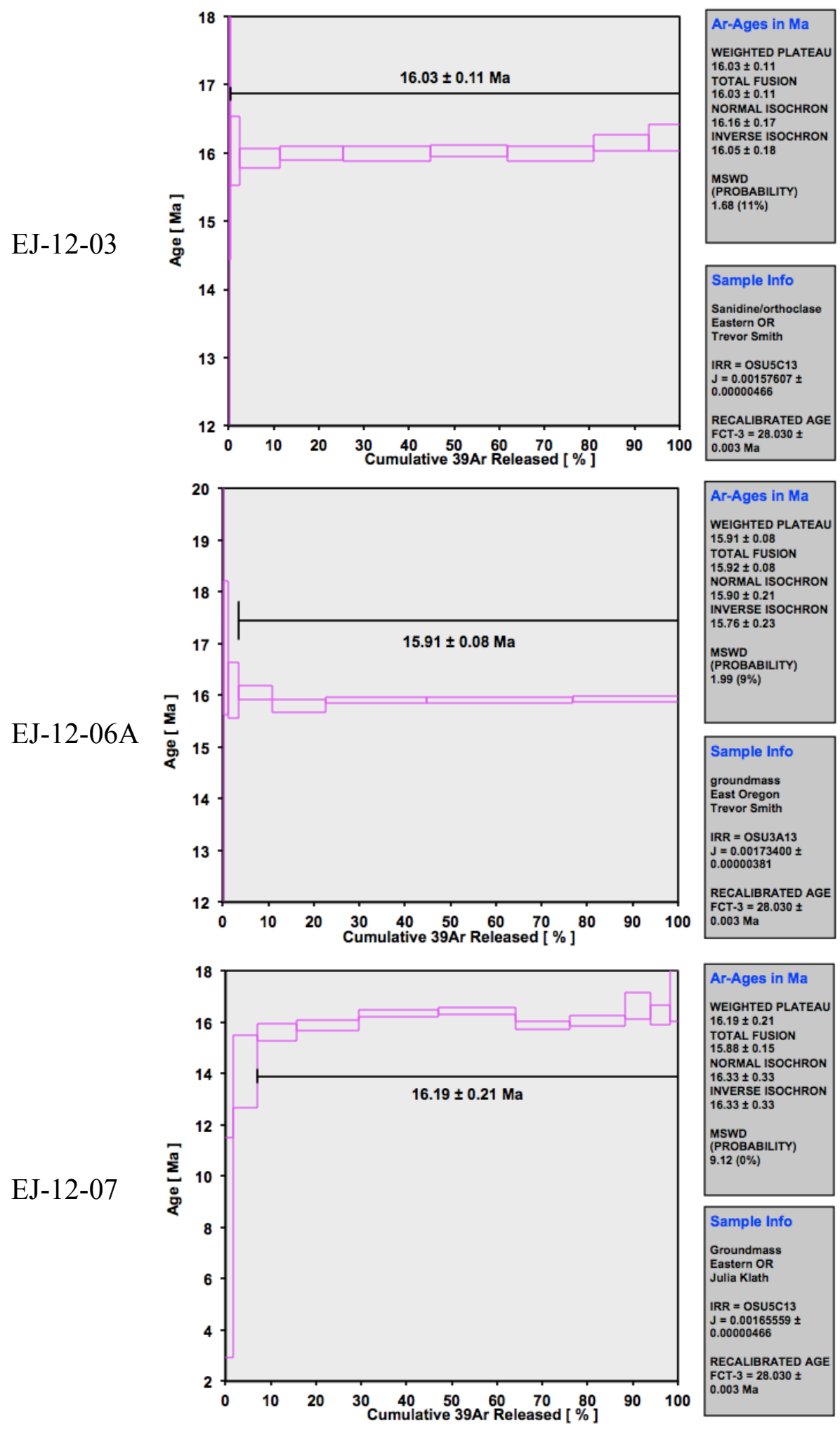

Figure 32. ${ }^{40} \mathrm{Ar} /{ }^{39} \mathrm{Ar}$ age plateau from incremental heating experiment. 

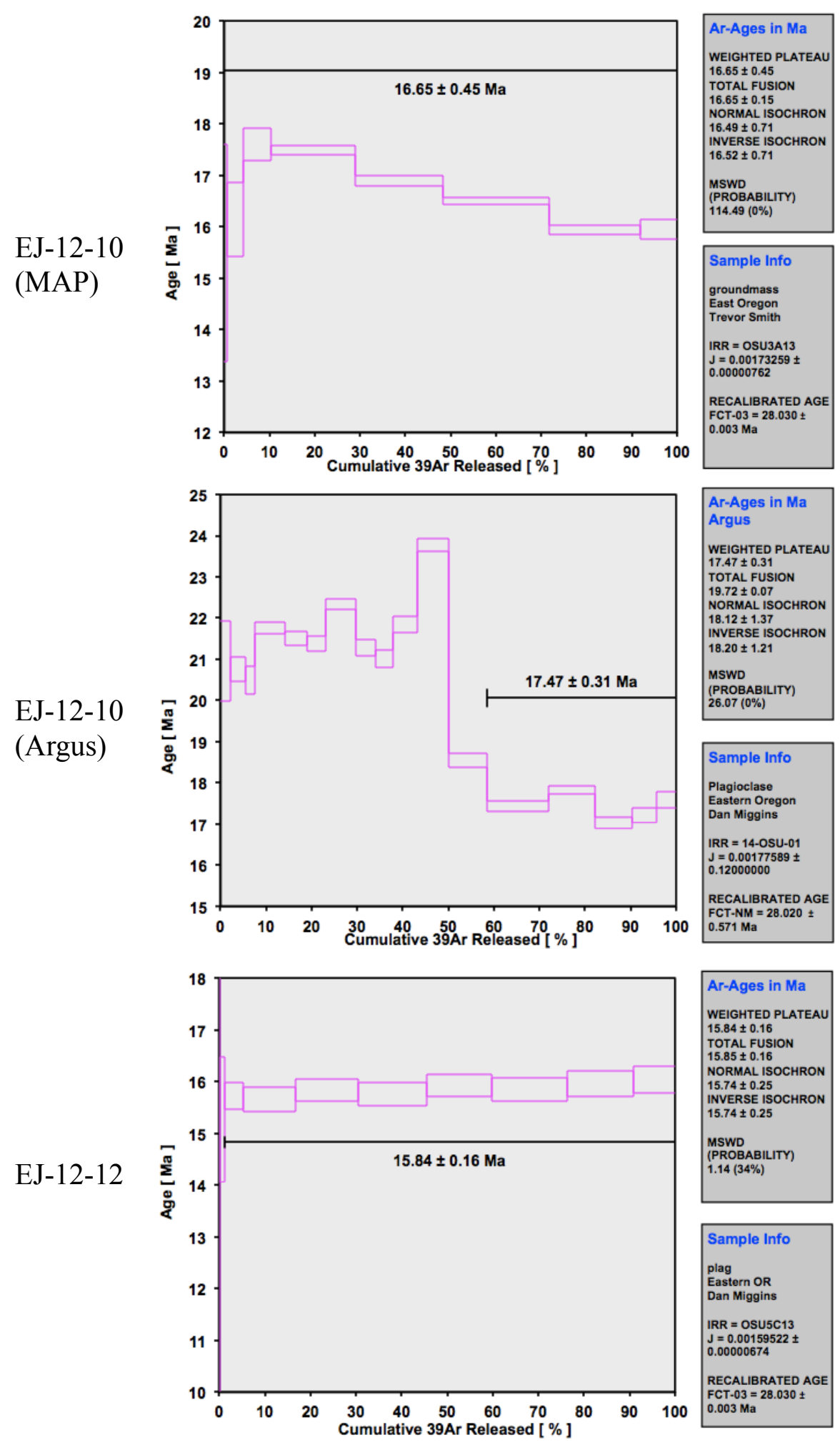

Figure 32 continued. ${ }^{40} \mathrm{Ar} /{ }^{39} \mathrm{Ar}$ age plateau from incremental heating experiment. 

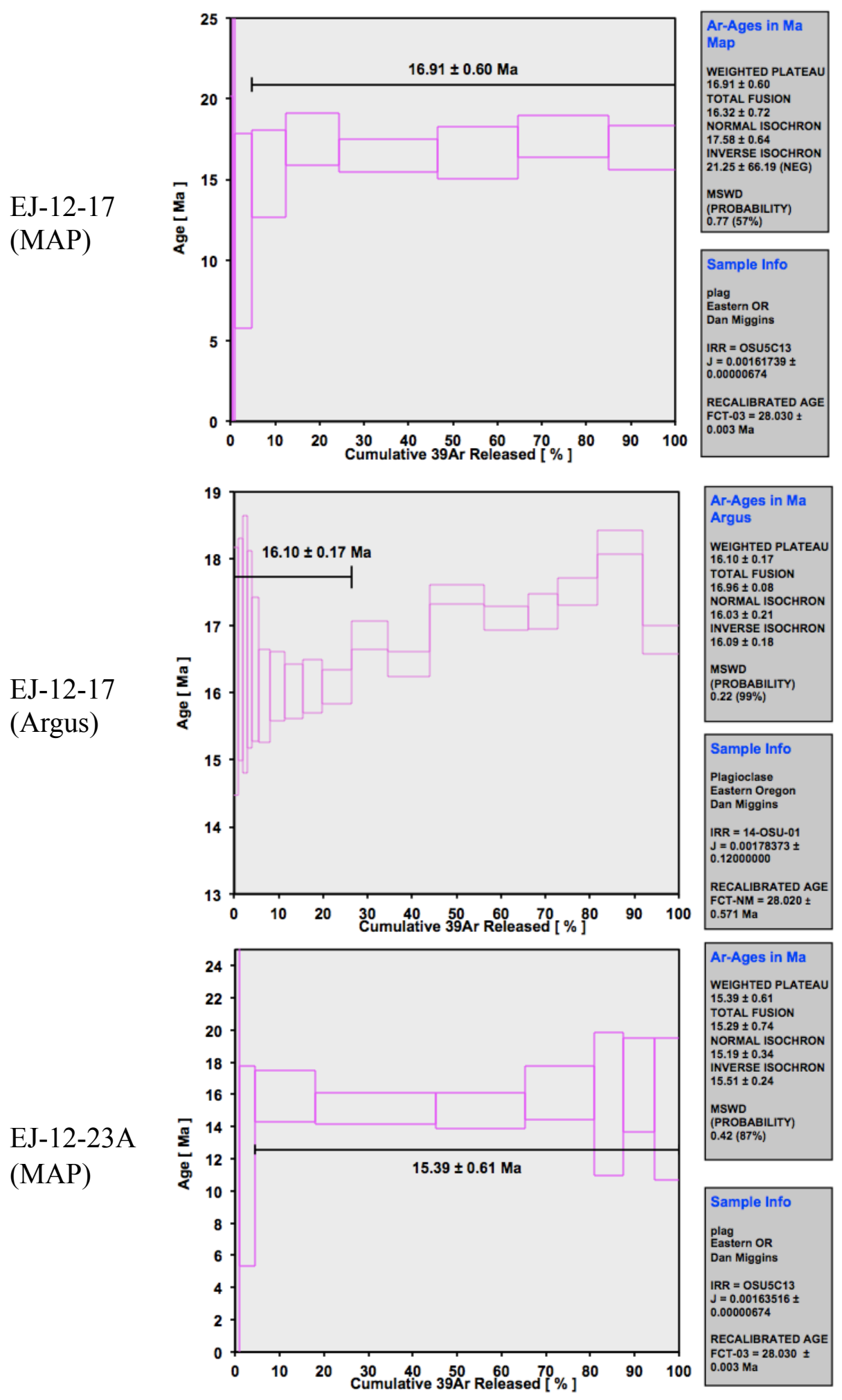

Figure 32 continued, ${ }^{40} \mathrm{Ar} /{ }^{39} \mathrm{Ar}$ age plateau from incremental heating experiment. 

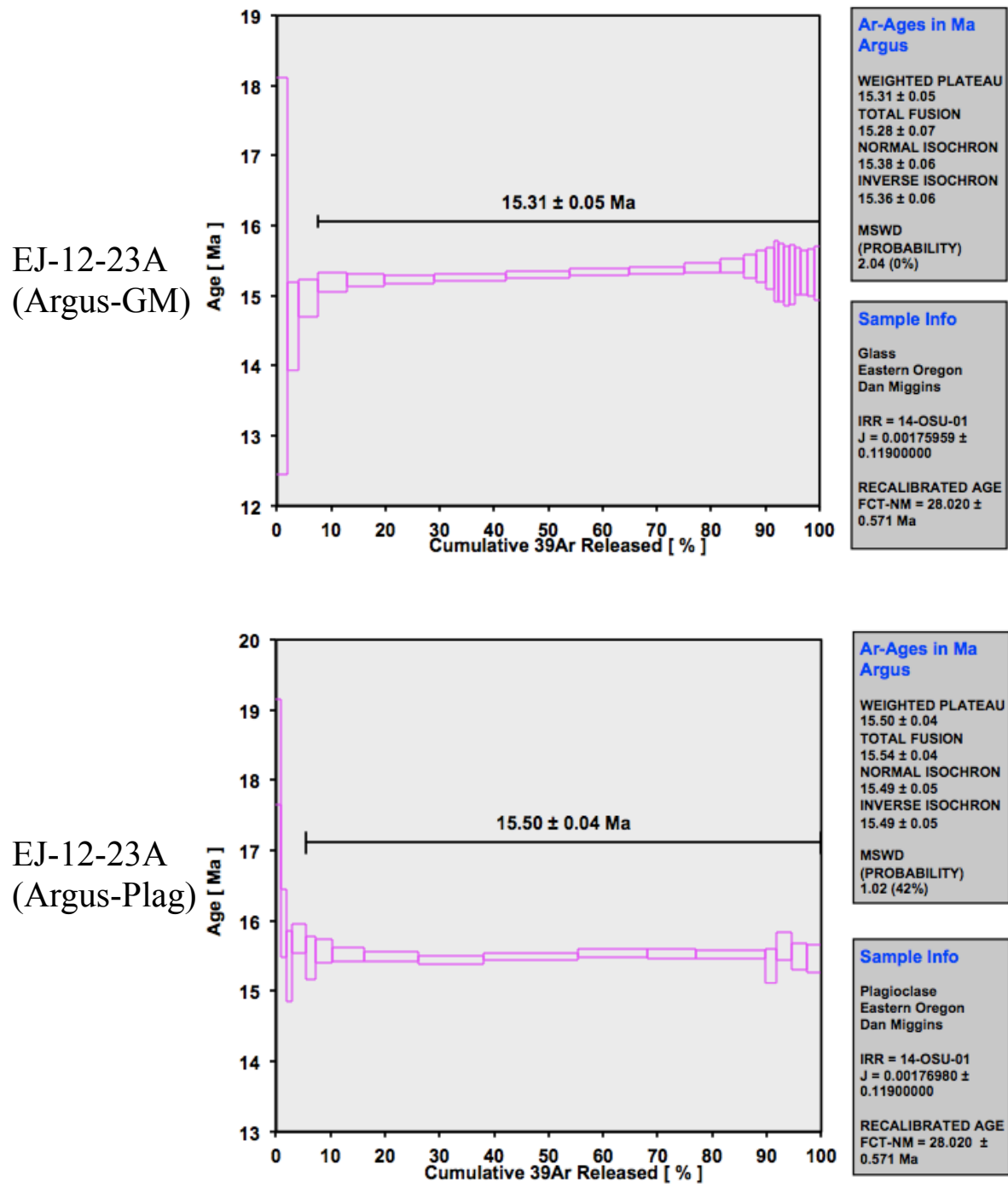

Figure 32 continued. ${ }^{40} \mathrm{Ar} /{ }^{39} \mathrm{Ar}$ age plateau from incremental heating experiment. 

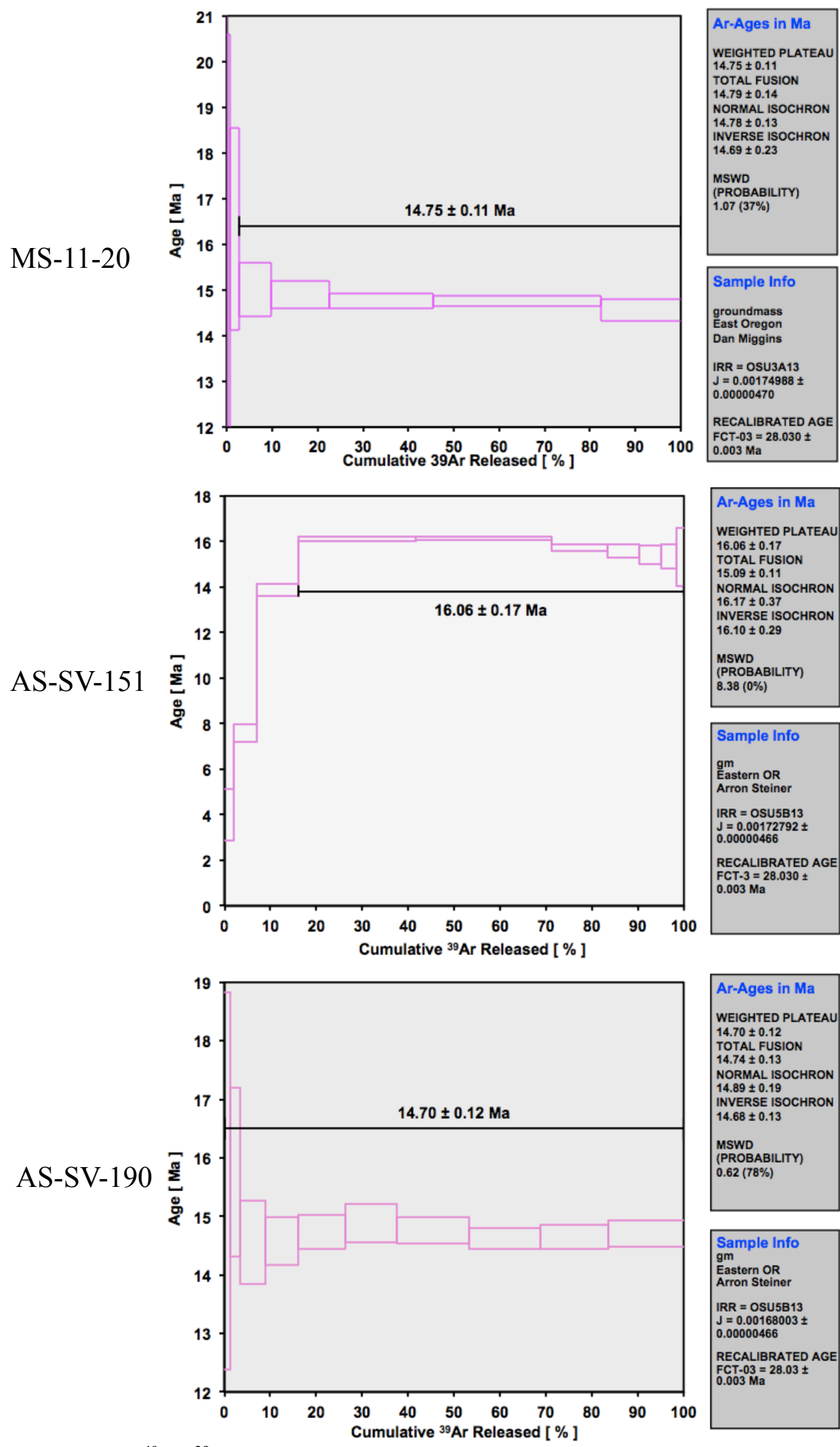

Figure 32 continued. ${ }^{40} \mathrm{Ar} /{ }^{39} \mathrm{Ar}$ age plateau from incremental heating experiment. 